\title{
Conditions for uranium biomineralization during the formation of the Zoovch Ovoo roll-front-type uranium deposit in East Gobi Basin, Mongolia
}

\author{
Dimitrios Rallakis ${ }^{1}$, Raymond Michels ${ }^{1}$, Michel Cathelineau ${ }^{1}$, Olivier Parize ${ }^{2}$ and Marc Brouand ${ }^{2}$ \\ ${ }^{1}$ Université de Lorraine, CNRS, CREGU, GeoRessources, 54504, Vandoeuvre-lès-Nancy, France \\ ${ }^{2}$ ORANO Mining, Le Prisme, 125 Avenue de Paris, 92320, Chatillon, France
}

\begin{abstract}
The Zoovch Ovoo uranium roll-front-type deposit is hosted in the Sainshand Formation, a Late Cretaceous siliciclastic reservoir, which constitutes the upper part of the post-rift infilling of the Mesozoic East Gobi Basin in SE Mongolia. The Sainshand Formation consists of unconsolidated medium-grained sand, silt and clay intervals deposited in fluvial-lacustrine settings. The uranium deposit is confined within a 60$80 \mathrm{~m}$ thick siliciclastic sequence inside aquifer-driven systems. The overall system experienced shallow burial and was never subjected to temperatures higher than $40^{\circ} \mathrm{C}$. This study proposes a comprehensive metallogenic model for this uranium deposit. Sedimentological and mineralogical observations from drill core samples to the microscopic scale (optical and Scanning Electron Microscopy) together with in situ geochemistry of late-formed phases (Laser Ablation-Inductively Coupled Plasma Mass Spectrometry, Electron Probe Microanalysis, Fourier Transform-Infrared Spectroscopy) were considered for the reconstruction of the main stages of $U$ trapping.
\end{abstract}


In the mineralized zone, the uranium ore is expressed as Ca-enriched uraninite $\left(\mathrm{UO}_{2}\right)$ and less commonly as Ca-enriched phospho-coffinite (U, P) $\mathrm{SiO}_{4}$. Trapping mechanisms include i) complexation (i.e. uranyl-carboxyl complexes), ii) adsorption on organic or clay particles) and iii) reduction by pyrite and by bacterial activity to amorphous uraninite. In all cases, the organic matter plays either the role of trap for uranium or nutrient for bacteria that can trap uranium through their metabolism. The shallow burial diagenesis conditions do not allow direct reduction of $\mathrm{U}(\mathrm{VI})$ by organic carbon. The $\delta^{34} \mathrm{~S}$ values of the iron disulfide are very diverse, fluctuating in extreme cases between -50 to $+50 \%$, with an average $\delta^{34} S$ value for framboidal pyrite at $2 \%$, and $-20 \%$ for euhedral pyrite. The positive and negative values reflect close versus open fractionation systems, while bacterial sulphate reduction (BSR) is active during the whole diagenetic history of the deposit as an essential source of reduced sulfur. Therefore, using detrital organic matter as a carbon source, microorganisms play a significant role in uranium trapping, either as a direct reducing agent for uranium or pyrite formation, which will trap uranium redox driven epigenetic processes.

Keywords: roll-front, uranium, bioreduction, organic matter, sulfur isotopes, East Gobi Basin, Mongolia

\section{Introduction}

The Central Asia Uraniferous Province, one of the most strategic areas in the world for uranium reserves, extends from Kazakhstan to the West towards the Transbaikal region to the East (Dahlkamp, 2009; Le Goux et al., 2015; IAEA 2018). Significant roll-front deposits exist all over this region, examples include the Chu-sarysu and Syrdarya basins in Kazakhstan (Aubakirov, 1998; Petrov 1998; Jaireth et al., 2008; Munara, 2012; Lach et al., 2015), the Songliao, Ordos and Erlian basins in China (Huang Xian-Fang et al., 2005; Min et al., 2005; Cai et al., 2007; 
Bonnetti et al., 2015a,b; Cao et al., 2016; Akhtar et al., 2017; Bonnetti et al., 2017; Jiao et al., 2018; Zhang et al., 2018; Yue et al., 2019) and the Unegt and Zuunbayan basins in Mongolia (Le Goux et al., 2015; Grizard et al., 2018; Boissezon et al., 2020; Rallakis et al., 2019; 2020).

Although these roll-front type uranium deposits might appear similar in terms of geochemical signatures and deposit geometry, there are significant differences in their paragenesis. The pre-ore uranium concentration in the sediments, the amount of detrital organic matter, the nature of uranium reducing agents, microorganisms' role, and uranium-hydrocarbon phase interactions may vary from one deposit to the other.

For example, mineralization in the Chu-Sarysu basin in Kazakhstan occurs in Paleocene continental arkosic sands deposited in fluvial settings, sourced from volcanic rocks (Aubakirov, 1998; Petrov, 1998; Munara, 2012). Uranium mineralization is associated with hydrothermal and biogenic pyrite (Lach et al., 2015). Although the proportion of organic matter in the mineralized grey sandstones is low (generally $0.03-0.05 \%$ C), Petrov (1998) suggests that this proportion is enough with a minor contribution of iron sulfides to produce large U-deposits in sandstone. Later studies (Jaireth et al., 2008) indicate that the redox conditions were favoured by the upward migration of gases from the oil field (including $\mathrm{H}_{2} \mathrm{~S}$ ) located below the Cretaceous sediments. U-deposits in sandstones located close to hydrocarbon reservoirs were also identified in the Ordos and Songlio basins in China (Huang Xian-Fang et al., 2005). The formation of uranium deposits in organic poor lithologies has been attributed to the input of $\mathrm{H}_{2} \mathrm{~S}$, along faults from deep hydrocarbon reservoirs (Reynolds and Goldhaber, 1978). Yet, the role of hydrothermal fluid in the systems is ambiguous and rarely proven, with the rare exception of deposits where fluid inclusions attest to the circulation of hot brines, sometimes with hydrocarbons or gases (Zhu et al., 2012).

Some of these deposits were intensively studied in the last decade, and several results point out the contribution of biological activity within the sedimentary reservoirs to explain the $U$ reduction. For example, in the Nuheting deposit in the Erlian basin, hydrocarbons and associated gases 
were invoked as potential reductants (Niu et al., 1995; Zhang and Ding, 1996 cited in Bonnetti, 2013 and Bonnnetti et al., 2015a). The data, however, do not support the hypothesis of hydrocarbons migrations as reducing agents for uranium mineralization. Thus, Bonnetti et al. (2015) indicated that the Nuheting deposit underwent three main stages of mineralization: (i) a synsedimentary/early diagenetic uranium concentration and mineralization, (ii) a late diagenetic in situ uranium remobilization and deposition on pyrite and (iii) epigenetic cementation. Another example is the Baxingtu uranium deposit in the Songliao Basin. It is hosted in the Late Cretaceous Yaojia Formation in medium to fine-grained channel sandstone with abundant type III and IV kerogen detrital organic matter. In rare cases, uranium mineralization was attributed mostly to bacterial processes responsible for uranium reduction (Bonnetti et al., 2017).

The present paper aims to fully characterize the U-minerals and their relationships with organic matter and sulfides. Specifically, the petrography of the detrital and diagenetic phases as well as the crystal chemistry of the latter help to build the paragenesis and identify the uranium mineralization episodes. The crystal chemistry of uranium phases reveals the presence of U-minerals, while the trace element content of pyrite seems to be a very effective index to distinguish between pre-ore and syn-ore pyrite generations. The stable isotopes, in particular the in situ $\delta^{34} S$ isotopic analysis of pyrite provide information on the origin of reduced sulfur, while its fractionation signifies the availability of reduced sulfur in the system during the evolution of the deposit. Organic petrography and Rock-Eval pyrolysis are used for the qualitative assessment of kerogen and its thermal maturity. By combining the above, it is possible to understand the mechanisms responsible for the formation of uranium mineralization, while their interplay yields a geochemical model for the Zoovch Ovoo deposit. 


\section{Geological setting}

\subsection{The East Gobi Basin}

Mongolia is separated into four metallogenic provinces that host $U$ mineralization, the Gobi-Tamtsag where the study area is located, the Khentei-Daur, the North Mongolian and the Mongol-Priargun. These provinces host over forty $U$ mineralization areas that differ in terms of geological setting, mineralization type, age and associated minerals (Figure 1A, B; Dahlkamp, 2009).

The East Gobi Basin is located in southeastern Mongolia (Figure 1). It includes four morpho-tectonic elements: the Unegt and Zuunbayan sub-basins as shown on the map and the Sainshand and Khovsgol sub-basins located SW and NE of the map, respectively (Prost, 2004). The $700 \mathrm{~km}$-wide by $300 \mathrm{~km}$-long northeast-southwest trending East Gobi Basin was formed during Mesozoic extension (Meyerhoff and Meyer, 1987; Prost, 2004; Johnson and Ritts, 2012).The Zuunbayan sub-basin hosts the Zoovch Ovoo uranium deposit (Figure 1C). The MesozoicCenozoic sedimentary sequence is estimated to approach about $4000 \mathrm{~m}$ in thickness. The granitic outcrops in the NE and S parts of the basin are probably the quartz arenite sandstone sources (Prost, 2004). In the Gobi-Tamtsag province, U deposits are found within the Upper Cretaceous (Cenomanian) Sainshand Formation. This post-rift sedimentary infill of the East Gobi Basin is composed of medium to coarsegrained sand deposited in fluvial to flood-dominated delta and lacustrine systems (Cardon et al., 2015; Le Goux et al., 2015).

\subsection{Tectonic history}

The East Gobi Basin is a multiphase deformation area (plate interior polyphase basin) that, according to recent studies and petroleumexploration seismic profiles, was subjected to four cycles of deformation and subsidence (Prost, 2004; Johnson and Ritts, 2012; Heumann et al., 2014), lasting from Late Paleozoic to Cenozoic: 
- Due to the Paleo-Asian Ocean's closure, the Late Permian post-collisional basin produced highly deformed and metamorphosed turbiditic sequences that are unconformably overlain by undeformed non-marine Permo-Triassic fluvial and alluvial sediments (Phase 1).

- A Late Triassic major sinistral shear zone (East Gobi Fault Zone) in southern Mongolia that formed major foreland and intramontane basins along with thrust sheets that carried Precambrian and early Paleozoic carbonate klippe over Permian and Triassic units. (Phase 2).

- The Late Mesozoic rift basin, lasting from the Late Jurassic to Late Cretaceous, is marked by the development of high angle normal faults (Phase 3).

- The Late Cretaceous post-rift succession and the development of a strike-slip basin marked by the regional unconformity and basin inversion. Although the sediments overlying the Late Cretaceous are characterized as a post-rift thermal sag phase, there were probably left-lateral strike-slip faults developing during the Early Cenozoic (Phase 4).

Finally, the Mesozoic sequence is covered by Tertiary-Quaternary fine to coarse-grained alluvial sediments, which form deposits of up to 5 $\mathrm{km}$ long and 1-2 km wide. Uplift episodes during the Early Cenozoic are also likely as older units outcrop locally among the Tertiary-Quaternary deposits (Prost, 2004) and are probably linked to the initiation of the Altyn Tagh fault in China during the Oligocene and Miocene (Johnson and Ritts, 2012). 


\subsection{Stratigraphy of the East Gobi Basin}

The lithostratigraphy of the East Gobi basin is presented in Figure 2. The Paleozoic basement stratigraphy (Devonian-Permian) consists of metamorphosed Paleozoic arc-related volcanics and marine siliciclastics forming the Tavan Tolgoy Unit (Traynor and Sladen, 1995; Lamb and Badarch, 1997; Graham et al., 2001). It is overlain unconformably by a 1000-4000 m thick continental sequence from Jurassic to Tertiary (Meyerhoff and Meyer, 1987; Prost, 2004). A hiatus of variable thickness exists between Permian and Middle Jurassic due to repeated episodes of block faulting and multiphase deformation (Johnson, 2004; Itterbeeck et al., 2005). The Khamar Khovoor Formation was deposited during the Middle and Upper Jurassic strata and is $750 \mathrm{~m}$ thick. The depositional setting at that time was paralic to marginal marine, with a combination of fluvial, lacustrine, deltaic and swamp-organic sedimentation. The fluvial character is expressed by braided rivers depositing sand and the paralic by dominant shale deposits. The Khamar Khovoor Formation forms a hiatus with the overlying Upper Jurassic (TithonianKimmeridgian) Sharlyn Formation that consists of $200 \mathrm{~m}$ of well-defined braided fluvial sandstones, conglomerates and to a lesser extent finer sediments, as lacustrine shales (Graham et al., 2001; Prost, 2004).

This was followed by a 300-700 m thick sequence consisting mainly of shales interbedded with coarser fractions (dark-coloured sandstones, conglomerates, siltstones) and volcanics (red-coloured tuffs, basalts) forming the Tsagaan Tsav Formation of Early Cretaceous (Valanginian) age. The Tsagaan Tsav Formation is composed of a fining upwards sequence of alluvial fan and braided stream deposits, which is topped by fine material deposited during flooding events (overbank deposits) and lacustrine facies (Graham et al., 2001; Johnson, 2004). The coarser sandstone part of the Tsagaan Tsav Formation is the reservoir unit for the Tsagaan Els and the Zuunbayan oil fields. The Zuunbayan Formation is Hauterivian to Albian and comprises $970 \mathrm{~m}$ of non-marine poorly compacted sandstones, interbedded with shales and volcanic tuff. The Zuunbayan Formation is divided into three different units: i) the organic-rich basal unit, which contains bituminous shales considered 
as potential source rock, ii, iii) the central and upper units, which include coals and sandstones with channel geometry along with basaltic flows (Prost, 2004).

Within the Zuunbayan sub-basin, the Sainshand Formation hosts the Zoovch Ovoo uranium deposit (Parize, 2013; Le Goux et al., 2015). The Sainshand Formation is of Cenomanian age, and its thickness varies between 100-350 m. The sub-units reflect different lacustrine and alluvial sedimentation cycles, setting up a combination of conglomerate, sand, silt, and clay sediments (Dahlkamp, 2009). The Sainshand Formation is overlain by the Late Cretaceous (Santonian-Turonian) Bayanshiree Formation, consisting mainly of reddish to greyish shales with minor sandstones with channel-shaped geometry (Graham et al., 2001; Johnson, 2004). The thickness of the next two Late Cretaceous lacustrine coarse clastic units, namely the Santonian-Campanian Baruungoyot Formation and the Campanian-Maastrichtian Nemegt Formation, is variable. The Upper Cretaceous post-rift sequence was deposited in a sag basin period (sediment starvation) and was affected by strike-slip tectonics later in Cenozoic. The series dip significantly along the faulted boundaries, whereas they are sub-horizontal in the core of the syncline. Locally, Tertiary and Quaternary strata are present due to vertical movements of the East Gobi Fault Zone (Johnson and Ritts, 2012; Heumann et al., 2014). They are generally undifferentiated with very fine to coarse sediments that unconformably overlie the Late Cretaceous strata (Prost, 2004).

In this tectonic framework, the burial history of the regional area of Zoovch Ovoo as well as the geothermal gradient $\left(4.5^{\circ} \mathrm{C} / 100 \mathrm{~m}\right)$ were based on Graham et al. (2001), Prost (2004), Rallakis et al. (2019; 2020). 


\section{Materials and methods}

\subsection{Uranium in the Sainshand Formation - Sampling}

As the uranium distribution varies with the development of redox fronts in roll-front systems, samples were recovered from drill-cores along profiles crossing oxidized, active roll-front as well as reduced zones (Figure 3). The locations of Profile 1 and 2 in the roll-front are indicated in Figure 1. The Zoovch Ovoo depocenter is mostly composed of unconsolidated sediments, such as silts and sands. Few consolidated facies are clay matrix-supported, and less commonly dolomite-cemented sandstones (Figure 4). The Sainshand Formation features record depositional conditions ranging from fluvial to flood-dominated delta and lacustrine systems (Dahlkamp, 2009; Parize, 2015; Le Goux et al., 2015).

\subsection{Petrography and chemistry}

The petrographic characteristics of the different types of minerals were studied in detail on polished thin sections ( 30 $\mu \mathrm{m}$ thick), using optical microscopy in transmitted and reflected light modes. The two methodologies used for their classification were based on Dott (1964) for petrography and Wentworth (1922) for granulometry.

A PHILIPS XL30 Scanning Electron Microscope (SEM), equipped with an energy dispersive spectrometer using a Si-(Li) semiconductor detector, coupled with a HITACHI S-4800 scanning electron microscope (SEM), to better observe the mineral paragenesis.

Electron probe microanalyses were carried out using a CAMECA SX100. The calibration was made using natural and synthetic oxides or alloys (orthoclase, albite, $\mathrm{MnTiO}_{3}$, wollastonite, hematite and olivine). The analytical conditions were: $10 \mathrm{nA}$ current, accelerating voltage of 15 $\mathrm{kV}, 10 \mathrm{~s}$ counting time for $\mathrm{K}, \mathrm{Na}, \mathrm{Ca}, 20 \mathrm{~s}$ for $\mathrm{Al}, \mathrm{Fe}, \mathrm{Mn}$ and $40 \mathrm{~s}$ for $\mathrm{Mg}$ and $\mathrm{U}$. 
The mineralogical analyses (XRD) were performed on bulk rock powder of carbonate cemented sandstones and on oriented clay extracts using a Bruker D2 Phaser equipped with a LynxEye XE-T detector. The interpretation software package used for the evaluation of the diffractograms was Diffrac.Suite along with EVA.

For the bulk rock geochemistry, the samples were initially dissolved in a microwave oven Milestone MLS 1200 Mega, using a solution of HF$\mathrm{HClO}_{4}-\mathrm{HNO}_{3}-\mathrm{H}_{2} \mathrm{O}_{2}$ (Cheburkin and Shotyk, 1996). The concentrations of the major elements (Ca, Fe, K, Mg and Na) were determined by Atomic Absorption Spectroscopy (AAS); trace elements (As, B, Ba, Co, Cr, Cu, Ga, Mn, Mo, Ni, Pb, Rb, Sr, U, V and Zn) were analyzed by Inductively Coupled Plasma Mass Spectroscopy (ICP-MS).

\subsection{Stable isotopes analysis}

In situ $\delta^{34} S$ isotopic analysis was performed on samples containing different pyrite habits. The analytical instrument used was a CAMECA IMS 1270 ion probe at the Jean Lamour Institute of the School of Mines (Nancy). The results were normalized using an in-house pyrite standard (Spain) and then treated using the formula described in Kitayama et al. (2012). The thin sections were gold coated before mounting. During the analysis, the pyrite crystals were sputtered with a $\mathrm{Cs}^{+}$beam source of 2-3 nA intensity inside a vacuum chamber, with $10 \mathrm{kV}$ acceleration voltage. Each spot analysis was performed under 40 cycles of 5 seconds each. 
3.4 Rare earth elements (REE) in uranium minerals and trace elements in pyrite

Rare Earth Elements (REEs) of uranium minerals were analyzed by Laser Ablation-Inductively Coupled Plasma Mass Spectrometry (LAICP-MS) at GeoRessources (Nancy). Laser ablation was performed with a $193 \mathrm{~nm}$ GeoLas Pro ArF Excimer laser (Microlas $\AA$, Göttingen, Germany) equipped with beam homogenization optics by focusing the beam at the sample surface with a constant fluency of $10 \mathrm{~J} / \mathrm{cm}^{2}$ and constant repetition rate of $5 \mathrm{~Hz}$. Helium was used as a carrier gas to transport the laser-generated aerosols from the ablation cell to the ICPMS. Ablated material was analyzed by an Agilent 7500c Quadrupole ICP-MS (Agilent ${ }^{\circledR}$, Santa Clara, California) equipped with an Octopole Reaction System with enhanced sensitivity optional lenses (Cs type, Agilent). The certified glass standards NIST610, NIST612 and NIST614 SRM, were used as reference materials (concentrations from Pearce et al., 1997) for the calibration of the LA-ICP-MS. The protocol for routine analysis of REE in uranium minerals was checked using an in-house reference uraninite standard. Absolute concentrations and detection limits were obtained from the equations developed by Longerich et al. (1996).

The suite of elements analyzed by LA-ICP-MS was La, Ce, Pr, Nd, Sm, Eu, Gd, Tb, Dy, Ho, Er, Tm, Yb, and Lu. Detection limits range from a few ppm for Ce to down to $0.5 \mathrm{ppm}$ for heavy rare earth elements. The REE spectra were normalized to the chondrite standard (Masuda et al., 1973; Anders and Grevesse, 1989).

The elements analyzed by LA-ICP-MS were V, Co, Ni, Cu, Zn, As, Se, Mo, Ag, Cd, Sb, Pb) in pyrite and Na, Mg, Si, P, Ca, Ti, Mn, Fe, Ni, $\mathrm{Cu}, \mathrm{Zn}, \mathrm{Rb}, \mathrm{Sr}, \mathrm{Y}, \mathrm{Ba}$ and $\mathrm{Pb}$ in U-bearing minerals. 


\subsection{Organic matter}

The macerals were identified using oil immersion microscopy (nomenclature after ICCP, 1963, 1971, 1975, 1998, 2001; Sýkorová et al., 2005; Suárez-Ruiz et al., 2012; Pickel et al., 2017). In core intervals enriched in organic carbon, coal is present as thin laminae within clays or is dispersed inside carbonate-cemented or un-cemented sands. Mechanical concentrates representing organic matter (40-70 mg), crushed down to $45 \mu \mathrm{m}$, of 14 samples namely, 9 sands with coal fragments, 3 organic matter-rich clays and 2 carbonate-cemented sandstones with organic matter were selected for Rock-Eval pyrolysis to determine their main geochemical parameters (Espitalie et al., 1985). The analyses were carried out in the Institute of Earth Sciences in Orléans (ISTO), France,

\section{Results}

\subsection{Nature of the sediments of the Sainshand Formation at the Zuunbayan sub-basin}

The upper part of the Cenomanian Sainshand Formation was sampled for this study. The lithologies encountered in the Zoovch Ovoo depocenter have a vast granulometric range from silty clays to gravels for the unconsolidated facies and from silty claystones to microconglomerates for the cemented facies. Based on 93 samples analyzed by point-counting, the lithologies encountered in Zoovch Ovoo were by order of abundance: a) $47 \%$ sands to sandstones with matrix content between $15-75 \%$, b) $32 \%$, sands with less than $15 \%$ matrix, c) $10 \%$ pyrite-cemented sandstones, d) 5\% sandstones cemented by iron oxides, e) $3 \%$ silty clays and f) 3\% carbonate-cemented sandstones (Figure A1). Based on the ICP-MS bulk rock data and the equations from Herron (1988), the lithologies are classified as sub-arkoses, arenites and silty claystones (Figure A2 in the annex). 
Two distinct units are identified in the sedimentological study (Parize et al., 2013). The first lithological unit consists of finely laminated to stratified monomict to polymict silty to sandy clay, corresponding to varves. The second unit is coarse-grained, sandy to (micro)-conglomeratic, monomict, with granules of intraclasts originating from the first unit. The coarse sediments indicate sudden episodes of sedimentation (floods). Sand dunes are intercalated between the two units that serve as uranium reservoirs, and uranium mineralization is confined in between the coarse (sand, conglomerate) and fine (silt, clay) units.

Detrital quartz, feldspars, biotite, muscovite and commonly lithic elements are the main detrital grains or clasts. Feldspar grains are often chemically altered by sericitication. Their shapes range from angular to sub-rounded with a maximum grain size of about $1 \mathrm{~mm}$ (Figure 5 ). Clay intraclasts up to pebble size are often present in sand layers and detrital rounded dolomite grains. Dolomite is microcrystalline and often associated with siderite (Rallakis et al., 2020).

The sandstones are, for the most part, composed of quartz (40 to $80 \%$ ), feldspars as K-feldspars (microcline, orthoclase, some \% to $25 \%$ ) and plagioclases (5 to 20\%), minor phases (apatite, ilmenite) and a few accessories of magmatic origin (monazite, zircon, xenotime, rutile, and anatase). The clay/phyllosilicate fraction (biotite, chlorite, muscovite in the coarse-grained fraction) is not abundant and not systematically present. Some tests on the clay mineralogy were conducted by means of X-Ray Diffraction. The analysis was repeated twice, one before (airdried) and one after ethylene-glycol treatment, since swelling clays were identified (Figure A3 in the annex). It was concluded that the predominant clay fraction is smectite (recognized by the typical swelling at 14-17 $\AA$ ), followed by kaolinite. In total 6 clay samples were analyzed, revealing the same pattern. 
The consolidated lithologies are only a few $\mathrm{dm}$ thick and correspond to dolomite- and pyrite-cemented sandstones, the cement accounting for $30 \%$ of sandstone volume on average. Four successive generations of dolomite are distinguished (Rallakis et al., 2020): type I (microcrystalline, pre-roll-front), type II (euhedral, pre-roll-front), type III (active roll-front) and type IV (post-roll-front).

Organic matter as detrital coal particles is widespread in all lithologies. The organic matter can be found as dispersed particles in sand, silt, and clay or concentrated within sandy laminae (Rallakis et al., 2019). Coal layers are absent in the Sainshand sand deposits, and the organic matter contained in the sediments occurs as detrital particles deposited along the sedimentary bedding. The coarse, angular and poorly sorted organic particles are linked to medium-sized lithologies (coarse to fine-grained sands). Organic matter particles encountered in fine clay (organic-rich) layers are better preserved and linked to calm depositional settings under less oxygenated conditions. Well preserved phytoclasts, such as root-relics, are often associated with fine-grained organic-rich lithofacies, which could indicate higher plants that grew within the depositional setting (no significant transport). For phytoclasts and root-relics please refer to Rallakis et al. (2019).

\subsection{Roll front mineralogy and zonation}

Uranium mineralization is confined to sand dunes between the coarse (sand, conglomerate) and fine (silt, clay) units. In the oxidized part of the roll-front, Fe-hydroxides and oxides, namely limonite $\left(\mathrm{FeO}(\mathrm{OH}) \cdot \mathrm{nH}_{2} \mathrm{O}\right)$, goethite $(\mathrm{FeO}(\mathrm{OH}))$, and hematite $\left(\mathrm{Fe}_{2} \mathrm{O}_{3}\right)$, are present. Entire layers of originally reduced grey claystone can become partially to totally red due to the introduction of iron oxides with the oxidizing roll-front waters (Figure 4). 
In the reduced part, euhedral pyrite is the most common authigenic mineral and was recognized in three forms, as framboids, as concentric overgrowth formed around framboids and as euhedral crystals (cubic). In a few cases, the polymorph of FeS ${ }_{2}$, marcasite can be identified, developing locally around euhedral pyrite.

Sphalerite is the second most common sulfide after pyrite and was encountered in many mineralized samples. Other sulfides include galena $(\mathrm{PbS})$, greenockite $(\mathrm{CdS})$ and acanthite $\left(\mathrm{Ag}_{2} \mathrm{~S}\right)$. These associated minerals are found rarely, and mainly contained in uranium-rich samples. Furthermore, barite $\left(\mathrm{BaSO}_{4}\right)$, gypsum $\left(\mathrm{CaSO}_{4} \cdot 2 \mathrm{H}_{2} \mathrm{O}\right)$ and the selenides, namely, clausthalite $(\mathrm{PbSe})$ and stilleite $(\mathrm{ZnSe})$, were recognized in minute quantities. Native selenium is often found associated with organic matter, mainly contained inside cell walls.

\section{3 $\mathrm{FeS}_{2}$ petrography}

A detailed study of the petrographic relationships between $\mathrm{FeS}_{2}$, detrital elements and other diagenetic mineral phases allowed us to identify several habits of pyrite: i) isolated framboids within the mineral network, ii) framboids within organic matter particles, iii) concentric overgrowth of framboids, iv) framboids embedded within cubic (euhedral) pyrite, v) series of cubic (euhedral) pyrite, vi) isolated euhedral pyrite, vii) marcasite on isolated euhedral pyrite and viii) framboidal and euhedral pyrite inside post-uranium dolomite.

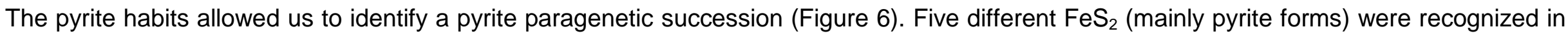
the following chronological order: i) framboidal pyrite, ii) concentric overgrowth, iii) euhedral pyrite 1 (pre-ore), iv) marcasite and v) euhedral pyrite 2 (ore-stage) often containing uraninite $\left(\mathrm{UO}_{2}\right)$ micro-inclusions. 
The first euhedral pyrite generation, which is formed during a pre-ore stage, shows corrosion features, hence suffered destabilization by circulating fluids (Figure 7A, B). The corrosion is lacking from the second euhedral pyrite generation, ore-stage pyrite, which, on the contrary, presents well-developed cubic crystals and may contain uraninite micro-size inclusions (Figure 7C, D). Marcasite was identified as pre-ore, precipitating directly after euhedral pyrite generation 1 (pre-ore). Sphalerite can contain pitchblende as fracture-filling cement or as spherical micro-inclusions. It definitely postdates the euhedral pyrite that does not contain uranium inclusions but is probably also post-diagenetic with regards to the pyrite that contains uranium inclusions, according to petrographic observations. Sphalerite is also separated in two categories, the Cd-rich (up to $14 \mathrm{wt} \% \mathrm{Cd}$ ) and the $\mathrm{Cd}$-poor (<3 wt\% Cd). Both sphalerite types may contain pitchblende inclusions.

Framboidal pyrite is commonly found inside or at the rim of organic particles, isolated or in groups (polyframboids). Typically, the cell lumens are used as nucleation sites controlling the morphology of the growing crystal. The degree of epigenetic replacement of organic matter by framboids and their overgrowths (concentric and euhedral pyrite generation 1 vary from a few dispersed framboids to full replacement. Pyrite has a higher affinity with the maceral collotelline (fused homogenous cell walls without defined cell structure) compared to the maceral telinite (fully or partially fused cell walls) or corpogelinite (discrete homogenous vitrinitic bodies representing the infilling of cell lumens). Even when the internal part of the cell walls is empty, i.e. fusinite, the framboids use it as a nucleation site and grow until they reach the borders of the cell walls that act as barriers to further crystal growth. Eventually, when uranium enters the system, the framboids and their overgrowths that have previously replaced organic matter will be gradually replaced by uranium. This epigenetic process is well demonstrated in Figure 7E, F. First framboidal pyrite replaced organic matter. Then uranium replaced pyrite. We are witnessing the second process. We know that pyrite replaced 
organic matter at the first place because we can see the relic of the organic particle (vitrinite). Profiles with decreasing concentration gradients on vitrinite particles have been published in Rallakis et al. (2019).

\subsection{Trace elements in $\mathrm{FeS}_{2}$}

Examples of different forms of pyrite, pyrite associated with $U$ cement, and sphalerite were analyzed for trace elements by LA-ICPMS. The concentric pyrite overgrowth could not be analysed as a separate phase from the framboids due to analytical limitations of the laser beam.

Vanadium and Zn concentrations in all pyrites are usually below 50 ppm and sometimes reach 200 and 100 ppm, respectively. Molybdenum concentrations are more variable, from below detection limit (1 ppm) to up to $3300 \mathrm{ppm}$.

Copper contents of framboidal pyrite range from 20 ppm up to $1000-3000$ ppm. Copper is generally below 100 ppm for the other pyrite types but can occasionally reach up to 500 ppm. Selenium is usually below the detection limit, but in some instances, both in framboidal pyrite and the other types, it can reach 2000 ppm. Cadmium and Sb are typically less than 100 ppm. Lead was detected in many different concentrations up to $6600 \mathrm{ppm}$ and may correspond partially to radiogenic $\mathrm{Pb}$. The geochemical plot of $\mathrm{Co}$ and Cd plot (Figure 8) distinguishes the different sulfide groups. Pyrite not associated with uranium is depleted in both Co and Cd, irrespective of their morphology. On the contrary, pyrite associated with uranium shows an enrichment trend in Cd (from a few ppm to 90 ppm) and Co (from a few ppm to 5500 ppm). The euhedral pyrite associated with marcasite contains around 1000-3000 ppm Co and high Cd contents between 100-190 ppm, while marcasite itself has low contents in $\mathrm{Cd}$ and Co. Finally, the euhedral pyrite associated with sphalerite has a low Cd concentration but up to 10000 ppm of Co are contained in the associated sphalerite. 


\subsection{Isotopic chemistry $-\delta^{34} S$ of pyrite}

The in-situ micrometer scale $\delta^{34} S$ analyses were performed on the various pyrite habits described above (Figure 9). The distribution of all the framboidal pyrite occurrences for $\delta^{34} S(n=22)$ ranges between -40 and $+52 \%$. The absolute distribution of $\delta^{34} S$ of all the euhedral/cement pyrite $(n=34)$ ranges from -50 to $+34 \%$. More specifically, uranium-associated pyrite (ore-stage pyrite) $\delta^{34} S$ ranges between -42 and $-22 \%$. Data for framboidal and euhedral pyritesoverlap over awide range of values. The distinction between framboidal and euhedral pyrite is more pronounced for the extreme values, as the highest (positive) values were obtained in framboids and the lowest (negative) values in euhedral pyrite (Figure 9). In general, the framboids tend to be slighter heavier in $\delta^{34} S$ than euhedral or cement pyrite. This feature is even more apparent for framboids associated with organic matter $\left(\delta^{34} S\right.$ ranges between +5 to $+55 \%$ ).

\subsection{Organic matter}

The macerals identified in the Zoovch Ovoo sands using oil immersion microscopy are presented in Figure 11. Most of the organic matter is, in general, highly altered due to oxidation and weathering, inherited by sedimentation or introduced by roll-front waters. The kerogen is mainly of type III (vitrinite) and type IV (inertinite). Few occurrences of type II (liptinite) and cutinite could be recognized (Rallakis et al., 2019).

In terms of Rock-Eval analysis (Table 1 and Figure A5), all kerogen samples studied present a very low Hydrogen Index and a linear trend for the Oxygen Index, indicating type III (vitrinite) and IV (inertinite) kerogens. At whole-rock scale, since uranium is very often associated with organic matter particles, an attempt was made to correlate the geochemical composition of kerogen with uranium content expressed by radioactivity (counts per second using a Radiagem SPP2 detector). Indeed, uranium can significantly modify kerogen geochemical composition (Rouzaud, 1980; Jaraula et al., 2015; Schulz et al., 2018; Zhang et al., 2019). Alteration processes that affect the organic matter associated to 
uranium deposits include weathering (surface), meteoric water influx (leaching by oxygenated waters), bacterial alteration and radiolysis (Landais et al., 1987; Forbes et al., 1988; Landais, 1996). As a result, the organic matter in U-deposits shows abnormal values which do not reflect their origin or thermal maturity. In other words, it displays very low $\mathrm{HI}$ and progressively higher $\mathrm{OI}$ due to radiolysis and probably due to alteration/oxidation processes; as well as mixed Tmax values i.e. $420-450^{\circ} \mathrm{C}$ that represent organic matter of low and high maturity at the same time (Espitalie et al., 1985). In Zoovch Ovoo uranium content does not seem to be directly related to the Oxygen Index (Figure A4). However, as the radioactivity measurements were performed at core scale, they may not represent the uranium concentration in the specific organic particles analyzed by Rock-Eval.

\subsection{Petrography of uranium minerals}

Uranium crystals were recognized in three forms: i) As independent spheres at the size range of $1 \mu \mathrm{m}$, ii) as elongated flakes iii) as large aggregates that resemble epigenetic replacement features of former organic matter particles, pyrite crystals or Fe-Ti oxides (Figure 12). Uranium can be contained in organic matter (OM) from very low (0.5 wt\%) to very high concentration grades (about 80 wt\%). In the last case, uranium replaces OM while preserving primary maceral textures. Isolated inclusions of uranium oxides are also found inside sphalerite and in one of the euhedral pyrite generations. U-oxides were also seen as dispersed inclusions within the clay matrix, deposited in the intergranular pores of dolomite-cemented sandstones, within the fractures of feldspar grains and as epigenetic replacement of pyrite. U-oxides can also totally replace $\mathrm{Fe}-\mathrm{Ti}$ oxides while preserving the former mineral texture.

Based on these observations, it was possible to identify eight different types of uranium occurrences from the studied dataset. 


\subsection{Geochemistry of uranium}

\section{a. The $(\mathrm{U}+\mathrm{Ca})$-Si-P ternary diagram}

Analyses of representative of $\mathrm{U}$-phases are plotted in the ternary diagram of $\mathrm{P}_{2} \mathrm{O}_{5}-\mathrm{UO}_{2}-\mathrm{SiO}_{2}$ (Figure 13) as a function of their host phase: $\mathrm{U}$ rich organic matter; U-replaced organic matter; U-replaced Fe-Ti oxides; U associated with subhedral dolomite cement; U associated with pyrite cement; $U$ associated with anhedral dolomite; $U$ in euhedral (cubic) pyrite; $U$ in corroded pyrite cement; $U$ in sphalerite and finally $U$ in a clay matrix.

Most of the data are distributed close to the uraninite endmember, with some $\mathrm{P}$ enrichment which causes a slight deviation from the stoichiometric formula $\mathrm{UO}_{2}$. Other analyses plot close to the phospho-coffinite stoichiometry, yet with slight $\mathrm{P}$ deficiency, and are interpreted as Phospho-coffinite. Pure coffinite is absent, and there is no continuous set of data from uraninite to phospho-coffinite, suggesting the absence of an overall uraninite to coffinite transformation. $U$ in clay matrix shows anomalous enrichment in $\mathrm{SiO}_{2}$ due to analytical interference with phyllosilicates. $\mathrm{P}_{2} \mathrm{O}_{5}$ content tends to indicate that the composition is similar to the samples plotting below phospho-coffinite composition (nonstoichiometric phospho-coffinite described above).

\section{b. The relationships between $U$ and organic matter}

The organic matter at Zoovch Ovoo is derived from land plants and occurs as detrital particles concentrated into clay layers, clay intraclasts or sandy laminae. Biological features of the particles are preserved depending on their transportation (proximal or distal origin). The thermal maturity of the organic matter is very low (peat to lignite stage). In the studied samples, $U$ is intimately associated with organic matter. Very 
high concentration (up to 20 wt\%) with no expression of uranium minerals was found in macerals (Rallakis et al., 2019) (Figure 14). Organic particles conserving their textural features are in some cases entirely replaced by U-oxides.

Also, $\mathrm{UO}_{2}$ can entirely replace organic matter particles with partial preservation of organic structure (suggesting epigenesis). As burial diagenesis is too low to envisage the reduction of $\mathrm{U}(\mathrm{VI})$ by organic matter (maximum temperature in the reservoir $<40^{\circ} \mathrm{C}$ ), the role of microorganisms for the reduction of $\mathrm{U}(\mathrm{VI})$, either directly through their physiological activity or by providing, reduced sulfur could be inferred. Finally, Fe(II) carboxylates were also considered as possible reducing agents (Boyanov et al., 2007).

\section{b. Geochemistry of uranium - REE patterns}

The REE pattern of the uranium minerals hosted in particular type of deposits i.e. roll-front, volcanic related, vein type and others may provide information linked to their genetic mechanism, thus permitting classifications in salinity, temperature and source. This approach became possible by studying and comparing the REE patterns of major uranium deposits worldwide for which the genetic mechanism is already known i.e. roll-front, volcanic-related, unconformity-related, intrusive etc. (Mercadier et al., 2011). The REE content of uraninite $\left(\mathrm{UO}_{2}\right)$ in Zoovch Ovoo was studied relative to different occurrences, i.e. (A) $\cup_{2}$ replacing organic matter, (B) $\cup_{2}$ associated with pyrite and $(C) \cup O_{2}$ in a clay matrix. The REE content was measured using LA-ICP/MS (Figure A5), and the data were normalized relative to chondrite (Anders and Grevesse, 1989). In all cases, the REE concentrations range between $10^{3}-10^{4}$ that of chondrite. Overall, two REE profiles were distinguished: one LREE enriched for the $\mathrm{UO}_{2}$-organic matter and $\mathrm{UO}_{2}$-pyrite and another $\mathrm{HREE}$ enriched for the $\mathrm{UO}_{2}$-organic matter and $\mathrm{UO}_{2}$-clay matrix. Both types of REE profile show a significant negative anomaly for Eu. 
Comparing the average REE concentrations on $\mathrm{UO}_{2}$ crystals and the bulk rock REE concentration (Figure A5), it appears that the average spectrum acquired on $\mathrm{UO}_{2}$ is approximately 100 times richer in REE than the bulk rock. Furthermore, the average spectrum of $\mathrm{UO}_{2}$ shows enrichment in HREE, while bulk rock data show the opposite trend. Both cases show a significant negative Eu anomaly. By comparing our data with Mercadier et al. (2011) it could be concluded that there is a good fit between the REE spectra of Zoovch Ovoo and the roll-fronts of Kazakhstan. The water source in the latter is meteoric, the $\mathrm{U}$-source is monazite and the temperature of formation does not exceed $50^{\circ} \mathrm{C}$.

\section{Discussion}

5.1 Mineral paragenesis in Zoovch Ovoo

The complete sequence of paragenesis from sedimentation through early diagenesis, roll-front formation, to late diagenesis processes at Zoovch Ovoo is summarized in Figure 15.

\section{Early diagenetic stage}

The organic matter observed in Zoovch Ovoo sediments is detrital and comes from two sources, one distal and one proximal, as suggested by the organic particles' preservation status. The low burial temperature conditions lead to the organic matter's low thermal maturity, which reached the lignite stage $\left(\% R_{r} \approx 0.4\right.$; Rallakis et al., 2019). 
Detrital sediments are neither affected by diagenesis nor by cementation. The dolomite cemented sandstone layers are an exception and their formation is linked to proto-dolomite deposition (Rallakis et al., 2020).

Dolomite types I (microcrystalline) and II (euhedral) were formed during early diagenesis and are associated with siderite. Siderite is the earliest expression of reduced iron implicated in diagenesis, indicating reducing conditions in the absence of a reduced sulfur source. The appearance of the first framboidal pyrite generation is diagnostic of the triggering of bacterial sulfate reduction. The overgrowth of pyrite and dolomite and the formation of the first euhedral pyrite generation and marcasite also belong to the pre-ore stage. Sphalerite 1 occurs after marcasite and marks the input of Zn enriched waters.

\section{Effect of roll-front waters}

The partial dissolution of the dolomite I and II due to the reactivity with the roll-front waters is responsible for forming secondary porosity and is followed by the formation of subhedral (type III) dolomite (Rallakis et al., 2020). The roll-front also affects the first euhedral pyrite and sphalerite generations, causing their epigenetic replacement by $\mathrm{UO}_{2}$. Furthermore, both the second euhedral pyrite and sphalerite generations are co-genetic to the first uranium precipitation episode since they contain uraninite inclusions (uraninite 1). The first uranium episode refers to the incipient stages of $U$ precipitation, followed by the second uranium episode, which refers to the massive introduction of $U$ in the system (uraninite 2). During the second U episode, uraninite tends to be accumulated as follows:

i. as uranium oxides at the rims of the organic particles $\left(\mathrm{UO}_{2}\right)$ : decreasing concentration gradients towards the inner part of the particles are observed, but the full replacement of the organic particle is possible.

ii. as uniform cement inside the clay matrix, preferentially on parts that were previously pyrite-cemented. 
iii. in the intergranular porosity between the detrital grains or in the secondary porosity caused by dolomite dissolution.

iv. and finally, by epigenesis of the first pyrite and sphalerite generations and the pyrite associated with organic matter.

\section{Late diagenetic stage}

The late diagenetic stage is characterized by the formation of anhedral (type IV) dolomite, precipitated from formation fluids very lean in REE. The strong negative Eu anomaly of this anhedral dolomite (Fowler and Doig, 1983; Rallakis et al., 2020) and the newly formed framboidal and euhedral pyrite found inside its lattice indicate post-roll-front reducing conditions, most likely during the uplift stage (Rallakis et al., 2019). Furthermore, type IV dolomite cement was confirmed in samples collected from the area outside the roll-front. Anhedral dolomite is therefore disconnected from the roll-front influence. It is also found in coarse to micro-conglomeratic lithologies suggesting a link with high permeability layers, in contrast with dolomite type I and II present in fine-grained sediments.

During late diagenesis, phospho-coffinite and quartz cement (authigenic quartz) formed locally, indicating mobility of Si and P from unknown sources (Figure 13). Mobilization of phosphorus may be linked to bacterial activity. Indeed, previous studies (Gächter and Meyer, 1993; Hutchens et al., 2006; Bonnetti et al., 2015b) have shown that microorganisms are responsible for the release of P from organic compounds as well as from the dissolution of apatite during BSR, where bacteria use P for their metabolism. Apatite is an accessory mineral that is very often encountered in Zoovch Ovoo.

The direct long-term contact of detrital grains, i.e. quartz, feldspars and micas with uraninite cement, induced radiation damage that formed pleochroic halos around these minerals, visible under cathodoluminescence (Figure A6). In particular, radiation halos were identified in quartz grains not in contact with phospho-coffinite cement. Keeping in mind that direct contact is needed between uranium minerals and quartz for 
alpha particles to penetrate the mineral lattice, this feature is evidence for uraninite cement deposition around detrital grains followed by dissolution and redistribution. Such processes were already described by Meunier et al. (1990a) and are characteristic of roll-front systems.

\subsection{Significance of the sulfide mineral habits and mineral chemistry}

Although euhedral pyrite is interpreted as abiotic in origin, framboidal pyrite may be related either to abiotic or biotic processes. Experiments on abiotic pyrite formation showed that framboids obtained in the laboratory are unstable and easily converted to euhedral pyrite (Sawlowicz, 2000). On the contrary, biologically derived framboids are stable in the presence of organic matter (MacLean et al., 2008). Therefore, pyrite occurring as stable framboids observed in sedimentary rocks is most often interpreted as derived from bacterial activity (Álvarez-lglesias and Rubio, 2012; Cavalazzi et al., 2014; Bonnetti et al., 2017; Hough et al., 2019). Also, low crystallinity iron sulfide (as mackinawite and greigite) has been detected in association with organic matter particles in our samples (Rallakis et al., 2019), a feature consistent with the activity of microbial sulfate reducers (Watson et al., 2000; Wolthers et al., 2000; Veeramani, 2013). Finally, at Zoovch Ovoo, pyrite is exclusively concentrated in laminae enriched in organic matter (Figure A7), while it is not present in surrounding facies. Hough et al. (2019) suggest that in roll-front systems, such a situation is a sign of pyrite formation in the presence of microorganisms. For all these reasons, we consider pyrite framboids in our samples as derived from sulfate-reducing bacteria (SRB) feeding on the detrital organic matter.

The first euhedral generation (pre-ore) pyrite seems to have formed as continuous overgrowths on framboids (framboidal pyrite 1) and their concentric overgrowths if present (Figure A8). This transformation is caused by minimizing the crystal surface energy during growth to become more stable (Sawlowicz, 1993; 2000). The genetic relationship is known because pyrite clusters of embedded framboids were found in the central part of euhedral crystals (Figure 8C-F). 
Marcasite can sometimes be observed at a paragenetic position between the first (pre-ore) and second (ore stage) euhedral pyrite generations. Therefore, it is the last pre-roll-front iron disulfide. As marcasite forms under a pH of 5 in the roll-front waters (Murowchick and Barnes, 1986; Anthony et al., 2003), it frequently has a specific position within the geometry of roll-fronts (Hough et al., 2019), which may explain its occasional observation in our samples.

All four pre-roll-front iron disulfides are characterized by a depletion in $\mathrm{Cd}, \mathrm{Co}$, $\mathrm{Ni}$ and to a lesser extent in $\mathrm{V}$, $\mathrm{Zn}$, Mo and $\mathrm{Cu}$, relative to the second euhedral generation formed during the ore-stage (Figure 8). Marcasite is significantly enriched in As compared to all other iron disulfides. According to Savage et al. (2000), Lowers et al. (2007), and Ingham et al. (2014), reduced arsenic (As ${ }^{-1}$ ) is incorporated in the iron disulfide lattice by substituting sulfur. Arsenic was probably scavenged due to low sulfur availability during the final iron disulfide formation before the roll-front waters recharge.

The petrographic analysis did not confirm any hydrothermal minerals or alterations. Hence, sphalerite must be attributed to the introduction of the roll-front waters that together with $\mathrm{U}$ carry metallic elements such as $\mathrm{Ni}, \mathrm{V}, \mathrm{Co}, \mathrm{Cd}, \mathrm{Zn}, \mathrm{As}, \mathrm{Pb}$ and others. Thus, this stage is marked by the ore-stage pyrite (euhedral generation 2) significantly richer in heavy metal elements, in contrast to pre-ore pyrite (framboids and euhedral generation 1) (Figure 8). Two reasons may explain the origin of the trace elements:

1) the roll-front waters are leaching these elements from host lithologies i.e. a combination of mafic rocks (Co, Ni; Goldschmidt, 1954; Clark et al., 2004), granitic rocks (Mo; Blevin et al., 1996) and organic-rich black shales (As, V; Brumsack, 2006) together with U. Indeed, meta-volcanic and intrusive rocks crop out in the vicinity of the Zoovch Ovoo depocenter, which could serve as potential sources (Graham, et al., 2001; Figure 1). 
2) these trace elements are incorporated in ore stage sulfides after being leached from pyrite by oxidizing waters during the roll-front displacement. The trace metals would then concentrate in the roll-front waters and be available to crystallize ore stage pyrite in the more reduced part of the roll-front (Descostes et al., 2010; Ingham et al., 2014; Bonnetti et al., 2020).

Concerning native Se found with organic matter, Ingham et al. (2014) proposed that in roll-front systems, Se is being scavenged from the dissolution of pre-ore pyrite or ideally from other Se-bearing minerals. Indeed, there are selenides in the Zoovch Ovoo reservoir, such as clausthalite $(\mathrm{PbSe})$ and stilleite $(\mathrm{ZnSe})$, potentially a source for Se.

\subsection{Interpretation of sulfur isotopes}

In the Sainshand Formation, detrital sediments (Figure 5) are dominated by quartz, feldspar and micas. Apart from the mineralized laminae enriched in organic matter, no pyrite is detected in the rocks. Therefore, the source and transport of sulfur available for mineralization must be related to the circulation of roll-front waters. Two possible sources may be considered:

1) Sulfates dissolved from evaporite deposits leached by the circulating waters. Considering that the Sainshand Formation temperature at Zoovch Ovoo never exceeded $40^{\circ} \mathrm{C}$ (Graham et al., 2001; Prost, 2004, Rallakis et al., 2019; 2020), reduced sulfur species could be obtained through bacterial activity. Such activity would lead to the formation of framboidal pyrite.

2) Sulfur species derived from the oxidative alteration of pyrite by roll-front waters. Indeed, (bio)-oxidation of pyrite in roll-front systems liberates intermediate valence sulfur species, which will contribute in the formation of pyrite in the roll-front (Granger and Warren, 1969; 
Rackley, 1972; Hough et al., 2019). In Zoovch Ovoo, the pre-ore pyrite present in the organic-rich laminae (framboidal pyrite 1, euhedral overgrowth and euhedral pyrite 1) would then become a possible initial pool of sulfur.

The $\delta^{34} S$ ranges from $+52 \%$ to $-52 \%$, which is very large but not unusual in roll fronts worldwide. There are examples of other roll-front deposits (Ingham et al., 2014; Bonnetti et al., 2015b; Lach et al., 2015; Hough et al., 2019; Bonnetti et al., 2020) that demonstrate similar values for the $\delta^{34} S$ of pyrite as those observed at Zoovch Ovoo (Figure 9). For instance, the deposit from Pepegoona and Pannikan (Lake Eyre Basin-South Australia) has pyrite with a range of $\delta^{34} S$ from -43.9 to $+32.4 \%$ (Ingham et al., 2014). Another example is Lost Creek and Willow Creek Mine Unit 10 (Wyoming-USA) deposits that have $\delta^{34}$ S from -68.1 to $+142.8 \%$ and from -48.1 to $+68.2 \%$, respectively (Hough et al., 2019). Bonnetti et al. (2020), in their study of the roll-front systems of the Mesozoic, found values between $-30.5 \%$ to $+18.8 \%$.

At first glance, very negative $\delta^{34} S$ values in pyrite from roll-front deposits are attributed to bacterial activity and more positive to abiotic pyrite precipitation mechanisms (Bonnetti et al., 2020). However, sulfur isotope values in roll-fronts also depend on redistribution mechanisms. Therefore, we plotted our data within the diagram proposed by Hough et al. (2019) in Figure 10 for comparison.

In our study, pyrite shows heavy $\delta^{34} S$ values $\left(+10\right.$ to $+52 \%$ ). According to literature, evaporites have a $\delta^{34} S$ range from +20 to $+35 \%$ (Makhnach et al., 2000) and can be considered a potential S source. Yet, pyrite $\delta^{34} S$ values higher than the mean evaporites composition imply an additional condition to fractionation. Alternately, according to the diagram of Hough et al. (2019), the highly positive $\delta^{34} S$ pyrite may also derive from a Rayleigh fractionation in closed isotopic systems. It is therefore suggested that pyrite (Figure 9 ) showing heavy $\delta^{34} S$ values (framboidal pyrite 1) may have been fractionated from evaporites-derived sulfate in a semi-closed isotopic system. Pyrite isotopic compositions 
also show $\delta^{34} S$ values expanding to lighter isotopic values (+10 to $\left.-52 \%\right)$. According to Hough et al. (2019), this might be linked to more opensystem conditions.

These authors also suggest that strong fractionation to negative values may suggest the effects of precipitation under neutral $\mathrm{pH}$ conditions and inheritance of light sulfur isotopes linked to multiple stages of pyrite dissolution/precipitation. Indeed, oxidation of pyrite deposited during previously occurring roll-fronts activity and subsequent sulfur disproportionation reactions may provide reduced sulfur species of light isotopic composition, even though dissolution and transport can both influence the isotopic distribution of sulfur (Seibert, 2017).

Pyrite habits (euhedral vs framboids) are well separated spatially and isotopically in other study cases (Hough et al., 2019). In the Erlian basin, pre-ore vs ore pyrite is well divided into pre-ore (framboids) vs ore (colomorph + subidiomorphic) pyrite generations with distinct isotopic signatures (Bonnetti et al., 2017). In our case, euhedral pyrites and framboids are spatially associated and (present multiple overgrowths) in the same mineralized laminae and have the same large span of isotopic compositions.

The large span of $\delta^{34} S$ values observed for all pyrite habits in our samples may be tentatively linked to fluctuating sulfate-containing water recharge periods alternating between open (high sulfate availability, recycling of isotopically light sulfur derived from altered pyrite) and a closed system (low sulfate availability, heavy isotopic enrichment). Both bacterial (framboids) or abiotic (euhedral) pyrite precipitation processes would have been submitted to this hydrological regime to lead to the very intricate pyrite petrography, and isotope geochemistry observed.

Framboidal pyrite 1 is the earliest pyrite generation observed and is followed by euhedral pyrite 1 (pre-ore) and euhedral pyrite 2 (contemporaneous to $U$ ore). Framboidal pyrite 1 would then represent the primary episode of reduced sulfur occurrence (hence controlled by bacterial sulfate reduction - BSR). Euhedral pyrite 1 and 2 (both of abiotic origin) would then derive from the recycling of framboidal pyrite 1 by 
the roll-front (since no other sulfur source is observed). However, pyrite is always located in the close vicinity of organic matter rich laminae, which suggests that whatever the pyrite generation, microbial activity controls the overall fate of reduced sulfur in the system (Figure A7).

The fate of sphalerite is very similar to euhedral pyrite (sphalerite 1 is pre-ore, sphalerite 2 contains micro-inclusions of uraninite). Yet, the origin of $\mathrm{Zn}$ is unknown.

\subsection{Uranium trapping processes involving pyrite}

The petrographic study of sulfides in the Zoovch Ovoo samples revealed widespread U-pyrite association. In many cases, epigenetic replacement of pyrite by uranium oxides is observed (Figure 7). Also, pyrite dissolution features exist (Figure 16). Both cases involve pre-ore pyrite (framboidal pyrite 1 and euhedral pyrite 2; Figure 7), suggesting sulfide instability in roll-front waters during uranium precipitation.

Dissolution of pyrite by roll-front waters would lead to $\mathrm{Fe}(\mathrm{II})$ liberation and reduced sulfur species $\left(\mathrm{S}_{0}\right.$, $\mathrm{HS}$, polysulfides). Fe(II) in solution may be considered as an efficient reducer for uranium (Boyanov, 2007; Du et al., 2011) as reduced sulfur species might be (Hua et al., 2006; Boonchayaanant et al., 2010). However, if dissolution occurs before uranium precipitation, the solute dispersion in the aqueous solution may prevent uraninite growth at the expense of pyrite.

It is more likely that the uranium reduction process may have happened at the contact with solid $\mathrm{FeS}_{2}$ as explained by Wersin et al. (1994) or Eglizaud et al. (2006). According to these authors, the interaction between pyrite and $\mathrm{U}(\mathrm{VI})$ is a two-step process. First, $\mathrm{U}(\mathrm{VI})$ is adsorbed on the pyrite surface, and then the redox reaction is initiated. Reduced uranium can be found either sorbed or precipitated as $\mathrm{UO}_{2}($ Eglizaud et al., 2006; Bruggeman et al., 2010). Progressive oxidation of $\mathrm{Fe}(\mathrm{II})$ and $\mathrm{S}_{2}^{-}$by $\mathrm{U}(\mathrm{VI})$ at the surface of the pyrite crystals lead from partial to complete 
replacement of $\mathrm{FeS}_{2}$ by $\mathrm{UO}_{2}$ (Figure 7E-F). This microsite redox chemistry would not preclude syn-ore euhedral pyrite 2 to precipitate with $\mathrm{UO}_{2}$ (Figure 7C, D) since overall pyrite precipitation is driven by the presence of reduced sulfur provided by thiosulfate disproportionation (Hough et al., 2019) and by BSR, as explained earlier.

Similar observations concern sphalerite: Sphalerite 1 generation occurs before $U$ precipitation in the diagenetic sequence and may show epigenetic replacement by uraninite. The second $\mathrm{ZnS}$ generation is co-genetic with $\mathrm{U}$ deposition and contains uraninite microsize inclusions (Figure 12C).

The biogenic iron sulfides, mackinawite and greigite, detected in association with organic matter particles (Rallakis et al., 2019), are also able to act as reducers of $\mathrm{U}(\mathrm{VI})$ to $\mathrm{UO}_{2}$ (Hua and Deng, 2008; Veeramani et al., 2013). It is also known that sulfate-reducing bacteria can generate reduced sulfur species such as $\mathrm{H}_{2} \mathrm{~S}$ and native sulfur (Gruner et al., 1953; Kochenov et al., 1977; Picard et al., 2017). These compounds can induce a reduction of dissolved uranium (Spirakis, 1996).

The sulfur isotopes data obtained on the Zoovch Ovoo pyrites give evidence of the availability of reduced sulfur produced through bacterial sulfate reduction. Indeed, pyrite, sphalerite mackinawite, and greigite are strongly associated with organic matter. Petrographic study of the uranium-sulfides relationships evidenced epigenesis and hence reduction of $U(V I)$ by sulfides. Thus, even though sulfides are responsible for $U$ precipitation, the sulfate-reducing bacterial community is the primary control of the precipitated uranium ore pool. 


\subsection{Uranium trapping processes involving organic matter}

Uranium occurs at Zoovch Ovoo very intimately associated with organic matter particles at high concentration without expression of a mineral phase or as $U_{2}$ replacing partially macerals with partial preservation of the original biological woody texture (Figure 14). Such $U$ concentrations in wood material (up to $80 \mathrm{wt} \% \mathrm{U}$ ) are the highest reported in literature (Rallakis et al., 2019). Simple adsorption/complexation cannot be ruled out but may not explain such concentrations.

$\mathrm{U}(\mathrm{VI})$ trapping mechanism in interstitial waters by organic matter was for many decades not very clearly understood when dealing with lowtemperature abiotic systems. Nakashima et al. (1984) and Nakashima (1992) and Cumberland et al. (2018) suggested that organic matter can trap uranium by complexation, forming uranyl-carboxyl functional groups. Such a process is possible for immature organic matter, such as peat, which may scavenge uranium by a factor of $10^{4}$ from groundwater containing uranium at ppb levels (Idiz et al., 1986; Owen and Otton, 1995). However, this process is not reduction [as $\mathrm{U}$ remains under the oxidized state as $\mathrm{U}(\mathrm{VI})$ ] but adsorption/complexation by carboxylic acids and phenolic groups of the immature organic matter (Warwick et al., 2005; Bryan et al., 2012).

Also, Nakashima et al. (1984) and Nakashima (1992) proved that direct reduction of U(VI) by organic matter (in particular by hydrocarbonaceous moieties) is only possible at $\mathrm{T}>120^{\circ} \mathrm{C}$. Such a process is unlikely to have occurred within the Sainshand formation since the temperature never exceeded $40^{\circ} \mathrm{C}$ (Graham et al., 2001; Prost, 2004; Rallakis et al., 2019; 2020).

\subsection{Organic matter and bacteria as redox trap for uranium}

The high concentration of $\mathrm{U}$ in the organic matter without expression of uranium minerals can be achieved via direct reduction of $\mathrm{U}(\mathrm{VI})$ by bacteria, leading to the formation of amorphous U(IV) (Bhattacharyya et al., 2017). The mechanism of U reduction through biomineralization by 
bacteria and fungi was also studied by Lovley et al. (1991) and by Min et al. (2005) in laboratory experiments and in roll-front systems, respectively. Micro-organism consortia can play a significant role in the control of the redox conditions for uranium precipitation as shown by these studies.

Biomineralization of uranium occurs then in two steps. First, the complexation of uranium, attributed to the bacterial excreted ligands around their cells as non-crystalline U(IV) (Bhattacharyya et al., 2017), whereas the precipitation that follows is accredited to the redox change, driven by enzymatic reactions (Gadd, 1996; Suzuki and Banfield, 1999; Wilkins et al., 2006). Such a process would lead to organic matter rich in U, presenting no expression of $\mathrm{UO}_{2}$ minerals as observed in our samples (Figure 14). Yet, Meunier et al. (1990b) considered that $\mathrm{U}$ was dispersed in the organic matter in similar cases, occurring under its reduced state $U(I V)$, forming very probably tiny-sized U oxide crystals. Such microminerals could not be observed at the highest SEM magnification yet cannot be excluded (Figure 14). Bhattacharyya et al. (2017) located U trapped in non-crystalline form, using synchrotron, in similar cases.

Uranium can be reduced by sulfate-reducing bacteria (Lovley et al., 1993; Wilkins et al., 2006; Cardenas et al., 2010) and to some extent by the methanogenic strains (Holmes et al., 2018). The chemical reactions and the bacteria species that could occur in such a process are presented in 
Table 2. In Zoovch Ovoo, bacteria could thrive in the low-temperature environment $\left(T<80^{\circ} \mathrm{C}\right)$, using the abundant coal fragments concentrated in laminae (Rallakis et al., 2019) as nutrients.

We might propose that organic matter is essential in trapping uranium through its role as a nutrient for micro-organism communities that control the trapping of uranium either by complexation-adsorption of $\mathrm{U}(\mathrm{IV})$ or direct reduction of $\mathrm{U}(\mathrm{VI})$. The continuous bacterial activity would progressively lead uranium to concentrate in the organic matter up to 20 weight\%, eventually under amorphous $\mathrm{U}(\mathrm{VI})$ form. $\mathrm{U}(\mathrm{VI}) \mathrm{may}$ also be reduced by microorganisms into $\mathrm{UO}_{2}$, as uraninite intimately associated with the fine organic structures (i.e. cellular walls geometry). With further organic carbon consumption by bacteria, $\mathrm{UO}_{2}$ may entirely replace the organic particles (Figure 7; Figure 14).

Pyrite is an efficient uranium reducing agent in Zoovch Ovoo (Rallakis et al., 2019), and is intimately associated with organic matter. Petrography and sulfur isotopes suggest that reduced sulfur present is derived from bacterial sulfate-reducing communities. Yet, such communities also need organic carbon as a nutrient. Therefore, the presence of organic matter is essential: 1) to BSR, which induces the formation of pyrite, a redox trap for $U ; 2$ ) to microbial communities, which act as a trap for $U$. In other words, organic matter plays a primary role in the formation of the ore deposit of Zoovch Ovoo since it sustains microbial activity and provides an efficient biogeochemical trap for uranium (Lovley et al., 1991; Detmers et al., 2001; Min et al., 2005; Menor-Salván et al., 2010).

\subsection{The model: biogeochemical roll-front trap of the Zoovch Ovoo uranium deposit}

The combination of the various biogeochemical processes described in this paper is summarized within a conceptual roll-front system in Figure 17. 


\section{Bio-reduction of sulfur, S-recycling in the roll-front and reduced iron availability}

Meteoric waters bearing sulfate and uranium percolate downdip through the permeable sandy horizons of the reservoir. In Zoovch Ovoo's case, sulfate could derive from the dissolution of sulfates (gypsum or celestite formed at the surface during evaporation), as was suggested by the strong positive $\delta^{34} S$ isotopic values of framboids (Figure 9). Sulfates might also derive from the oxidation of pyrite by dissolved oxygen (Stumm and Lee, 1961) and the activity of micro-organisms like Thiobacillus ferooxidans present in the percolating surface waters (Rackley, 1972). Consequently, Fe(III) precipitates as hydroxides (goethite/limonite) and oxides (hematite) (Schwertmann, 1991).

In the suboxic part of the roll-front, dissolution of phyllosilicates (e.g. biotite) and ilmenite, abundant in the Sainshand formation (Figure 5), may release $\mathrm{Fe}(\mathrm{II})$. Updip pyrite dissolution may also provide Fe(II) and reduced sulfur species available for the precipitation of euhedral pyrite (Granger and Warren, 1969; Boulegue, 1981; Brunner and Bernasconi, 2005; Hough, 2019). The subsequent pH drop would explain the dolomite dissolution features observed in dolomite types that were formed prior to the introduction of roll-front waters i.e. microcrystalline (type I) and euhedral (type II) dolomite.

In the reduced part of the roll-front, bacteria like the genus Desulfovibrio would be present and reduce sulfate (the dominant sulfur source) into sulfides (Rackley, 1972), producing intermediate valence species of sulfur (such as $\mathrm{S}_{2}^{-}, \mathrm{HS}^{-}, \mathrm{H}_{2} \mathrm{~S}, \mathrm{~S}_{0}$ ) (Figure 17, sulfate reduction). Reduced iron would then react with the reduced sulfur leading to the formation of framboidal pyrite. The resulting $\mathrm{pH}$ increase would allow subhedral (type III) dolomite, indicative of roll-front activity, to precipitate if the $\mathrm{Mg}$ concentration and carbonate activity in the waters is sufficiently high (Rallakis et al., 2020).

$\underline{U}$ reduction process and deposit formation 
Bio-reduction of $U$ is an essential process for reducing uranium at near-surface temperatures (Rackley, 1972; Huang, 1978; Lovley et al., 1991). Bacteria would then reduce $U(V I)$ to form non-crystalline $U(I V)$ (Bhattacharyya et al., 2017) and uraninite/coffinite. Thus, organic matter plays a central role in the metallogenic system. It concentrates uranium by adsorption or complexation and is also a source of nutrients to sustain bacterial activity responsible for metal reduction.

\section{Importance of uplift}

The relatively shallow aquifers probably underwent a nearly continuous bacterial activity responsible for many chemical features and processes controlling the $U$ and sulfide precipitation. However, the main uranium deposition events occured since the beginning of uplift when enhanced fluid movement sustained roll-front activity.

The rifting phase in East Gobi Basin ceased at the end of Early Cretaceous. From Cenomanian and on, the sedimentary sequence in Zoovch Ovoo experienced uplift and erosion (estimated at $300 \mathrm{~m}$ at maximum), entering the thermal cooling phase (Prost, 2004; Graham et al., 2001). During the Tertiary, the Zuunbayan fault system was reactivated with strike-slip movement (Johnson and Ritts, 2012; Heumann et al., 2014) moving the reservoir from 500 to $200 \mathrm{~m}$ - present day depth. These local tectonics could be responsible for opening the system, allowing meteoric waters to percolate through Sainshand Formation, carrying dissolved uranium in oxidized state as $\mathrm{U}(\mathrm{VI})$ as well as $\mathrm{Fe}(\mathrm{III}), \mathrm{SO}_{4}{ }^{2-}$ and bacteria. This new water mass was certainly in disequilibrium with dolomite and had a higher oxidation state than the Sainshand aquifer. The disequilibrium is evidenced by the dissolution features of the pre-roll-front dolomite cements and the deposition of $U$ minerals in the secondary porosity as well as by the appearance of the subhedral (type III) dolomite. With progressive uplift, parts of the roll-front were cut-off and reducing conditions were locally re-established. In sediments that are not leached by the roll-front waters, the type II dolomite does not show 
any dissolution features. Consequently, these parts were re-equilibrated with the aquifer waters which were saturated with respect to dolomite. Thus, the remaining uncemented sand layers, particularly the coarser units were percolated by the aquifer waters allowing the anhedral (type IV) dolomite cement to precipitate. In a previous study (Rallakis et al., 2020) the four dolomite petrographic types, as presented in the paragenesis table from type I to IV (Figure 15) and discussed chronologically in this chapter, were used to track the burial history of the reservoir.

To conclude the uplift episodes in Cenozoic displaced and combined the biochemical trap ingredients, allowing progressive enrichment in uranium through time.

\section{$\underline{\text { Late processes }}$}

During the stages of the roll-front activity, uraninite often experienced coffinitization with phosphorus incorporation leading to phosphocoffinite $\left(\mathrm{U}, \mathrm{P}\left(\mathrm{SiO}_{4}\right)\right.$ (Figure 13). Previous studies (Gäcther and Meyer, 1993; Hutchens et al., 2006; Bonnetti et al., 2015b) have shown that micro-organisms are responsible for releasing $\mathrm{P}$ from organic compounds as well as from the dissolution of apatite during BSR. It remains, however, to determine whether $\mathrm{P}$ is coming from organic compounds or from the dissolution of apatite, which is a common accessory mineral in the Zoovch Ovoo sands. 


\section{Conclusion}

The Zoovch Ovoo U-ore deposit was formed in uncemented sands deposited in fluvio-lacustrine settings, where relatively abundant coal particles were concentrated as laminae. This feature is a crucial parameter for the precipitation of sulfides and uranium ores.

The mineral sequence proposed in this study highlights multiple episodes of sulfides (essentially pyrite, sphalerite) and uranium deposition (non-crystalline, uraninite, phospho-coffinite). Sulfides precipitated during pre-, syn- and post-ore stages as reflected by specific contents in trace metals. The $\delta S^{34}$ compositions changes are, however, not consistent with pyrite morphology or generation. The heavy $\delta^{34} S$ values of pyrite between $+10 \%$ to $+52 \%$ are controlled by sulfate inputs, sulfur recycling from sulfides, and bacterial sulfate reduction under conditions of open and closed systems.

Regarding the very close association of sulfides with organic matter particles, bacterial activity is suspected as a significant provider of reduced sulfur. Since the burial temperature of Sainshand formation never exceeded $40^{\circ} \mathrm{C}$, direct reduction of uranium by organic matter could be excluded, considering that temperatures over $120^{\circ} \mathrm{C}$ are required for direct reduction. Unusually high concentrations of up to 20 wt $\%$ of uranium within organic matter without crystalline expression (amorphous) suggests that bacteria play an essential direct role in the trapping process. The continuous bacterial activity would increase the uranium concentration until the uraninite mineral forms, accompanied by the destruction of organic carbon, leading to total replacement features resembling epigenesis.

Pyrite epigenesis by uranium is also the central trapping mechanism, implying the reduction of U(IV) by solid reduced sulfur (and Fe(II) to some extent). It appears that the significant reducing agents for uranium in the Zoovch Ovoo are micro-organisms and sulfides. Also, bacteria have a major influence on the sulfur cycle, controlling a part at least. Their intimate association with organic matter-rich laminae is explained by 
considering coal particles as a carbon source for microorganisms. Therefore, the Zoovch Ovoo uranium ore deposit may be considered as a (bio)-geochemical trap. It appears that the relatively shallow aquifers probably underwent a nearly continuous bacterial activity which is responsible for many chemical features and processes controlling $U$ and sulfide precipitation. However, major uranium deposition events occurring since the beginning of uplift (Oligocene-Miocene) triggered enhanced fluid movements, sustaining roll-front activity. The latter displace and combine the bio-(geo)chemical trap ingredients, allowing progressive enrichment in uranium through time.

The exact uranium source is not easy to identify; however, the following formations outcrop in the region and have strong potential to act as such: 1) the granitic, 2) metamorphic and 3) volcanic basement rocks and 4) the volcanic ash/glass that covers Sainshand Formation.

The enrichment of ore-stage sulfides in certain trace elements is a probably a gradual process ( $\mathrm{Ni}, \mathrm{V}, \mathrm{Co}, \mathrm{Cd}, \mathrm{Zn}, \mathrm{As}, \mathrm{Pb}$ and others). It is linked to the continuous dissolution of pre-ore sulfides in the oxidized zone of the roll-front and the formation (re-precipitation) of ore-stage sulfides at the roll-front interface, in the same sense that the concentration gradient of uranium ore increases as the roll-front evolves.

Deposition of the ore is therefore dependent on circulating fluids carrying $U$ reaching the organic-rich laminae. This hydrologic factor is controlled by the permeability network inherited from sedimentation allowing the input of $\mathrm{S}, \mathrm{U}$ and micro-organisms by percolating waters. Knowledge of the spatial sedimentary organization of the most transmissive layers and distribution of organic matter are, therefore, two crucial parameters for further prospection. 


\section{Acknowledgements}

This work was performed and funded in the research framework between ORANO Mining and CREGU (Centre de Recherches sur la Géologie des Matières Premières Minérales et Energétiques), in the Laboratory of GeoRessources in Nancy, France (contract number 40077759 of 15/03/2016). We are grateful to COGEGOBl's geological team for the hospitality and the equipment provided during the field work as well as for taking care of the shipping of the samples from Mongolia to France. People from the laboratory of GeoRessources, in particular Marie Christine Boiron and Chantal Peiffert, are acknowledged for their contribution to the REE in situ analysis. Andreï Lecomte and Olivier Rouer are acknowledged for the crystal chemistry analyses and the manipulation of the analytical means. A special thanks to Denis Mangin from the Institute of Jean Lamour of the School of Mines in Nancy (France) for the in situ analysis of the S isotopes and to Mohammed Boussafir from the Institute of Earth Sciences in Orleans (France) for the Rock-Eval analyses. Finally, the authors would like to acknowledge the two anonymous reviewers that played a catalytic role in polishing the present manuscript.

\section{References}

AKHTAR, S., YANG, X., PIRAJNO, F. (2017). Sandstone type uranium deposits in the Ordos Basin, Northwest China: A case study and an overview. Journal of Asian Earth Sciences 146, 367-382.

ÁLVAREZ-IGLESIAS, P., \& RUBIO, B. (2012). Early diagenesis of organic-matter-rich sediments in a ría environment: organic matter sources, pyrites morphology and limitation of pyritization at depth. Estuarine, Coastal and Shelf Science, 100, 113-123.

ANDERS, E., GREVESSE, N. (1989). Abundances of the elements - Meteoritic and solar. Geochimica et Cosmochimica Acta, vol. 53, pp. $197-214$. 
ANTHONY, J.W., BIDEAUX, R.A., BLADH, K.W. NICHOLS, M.C. (2003). Eds., Handbook of Mineralogy, Mineralogical Society of America, Chantilly, VA 201511110, USA. http://www.handbookofmineralogy.org/.

AUBAKIROV, KH.B. (1998). On the deep origin of ore-forming solutions in the uranium deposits in platform sequence of depressions (with Chu-Sarysu Province as an example). Geology of Kazakhstan 2(354), pp. 40-47.

BLEVIN P.L., CHAPPELL B.W. AND ALLEN C.M. (1996). Intrusive metallogenic provinces in eastern Australia based on granite source and composition. Trans. R. Soc. Edinb. Earth Sci. 87, 281-290.

BHATTACHARYYA, A., CAMPBELL, K.M., KELLY, S.D., ROEBBERT, Y., WEYER, S., BERNIER-LATMANI, R., BORCH, T. (2017). Biogenic non-crystalline U(IV) revealed as major component in uranium ore deposits. Nature communications, 8, doi.10.1038/ncomms15538

BOISSEZON, H.DE., LEVY, L., JAKYMIW, C., DISTINGUIN, M., GUERIN, F., DESCOSTES, M. (2020). Modeling uranium and 226Ra mobility during and after an acidic in situ recovery test (Dulaan Uul, Mongolia). Journal of Contaminant Hydrology, 103711, ISSN 0169-7722, https://doi.org/10.1016/j.jconhyd.2020.103711.

BONNETTI, C., CUNEY, M., MALARTRE, F., MICHELS, R., LIU, X., PENG, Y. (2015a). The Nuheting Deposit, Erlian Basin, China: Synsedimentary vs Diagenetic Uranium Mineralization. Ore Geology Reviews, 69, pp. 118-139. doi.org/10.1016/j.oregeorev.2015.02.010

BONNETTI, C., CUNEY, M., MICHELS, R., TRUCHE, L., MALARTRE, F., LIU, X., YANG, J. (2015b). The Multiple Roles of Sulfate-Reducing Bacteria and Fe-Ti Oxides in the Genesis of the Bayinwula Roll Front-Type Uranium Deposit, Erlian Basin, NE China. Economic Geology, V. 110, pp. $1059-1081$.

BONNETTI, C., LIU, X., ZHAOBIN, Y., CUNEY, M., MICHELS, R., MALARTRE, F., MERCADIER, J., CAI, J. (2017). Coupled uranium mineralization and bacterial sulphate reduction for the genesis of the Baxingtu sandstone-hosted U deposit, SW Songliao Basin, NE China. Ore Geology Reviews, 82, pp. 108-129.

BONNETTI, C., LINGLI, Z., RIEGLER, T., BRUGGER, J., FAIRCLOUGH, M. (2020). Large S isotope and trace element fractionations in pyrite of uranium roll fron systems result from internally-driven biogeochemical cycle. Geochimica et Cosmochimica Acta, vol. 282, pp. 113-132. doi.org/10.1016/j.gca.2020.05.019

BOONCHAYAANANT, B., GU, B., ORTIZ, M.E., CRIDDLE, C.S. (2010). Can microbially-generated hydrogen sulfide account for the rates of U(VI) reduction by a sulfate-reducing bacterium?. Biodegradation, 21, pp.81-95. 
BOULÈGUE, J. (1981). Simultaneous Determination of Sulfide, Polysulfides and Thiosulfate as an Aid to Ore Exploration. Developments in Economic Geology, 15, pp. 21-36. doi.org/10.1016/0375-6742(81)90053-4

BOYANOV, M., O'LOUGHLIN, E.J., RODEN E.E., FEIN, J,B., KEMMETH, K.M. (2007). Adsorption of Fe(II) and U(VI) to carboxyl-functionalized microspheres: The influence of speciation on uranyl reduction studied by titration and XAFS. Geochimica et Cosmochimica Acta, vol. 71, pp. 1898-1912. DOI: 10.1016/i.gca.2007.01.025

BRYAN, N.D., ABRAHAMSEN, L., EVANS, N., WARWICK, P., BUCKAU, G., WENG, L., VAN RIEMSDIJK W.H. (2012). The effects of humic substances on the transport of radionuclides: recent improvements in the prediction of behaviour and the understanding of mechanisms, Applied Geochemistry, 27 (2), pp. 378-389.

BRUGgemAN, C., MAES, N. (2010). Uptake of Uranium(VI) by Pyrite under Boom Clay Conditions: Influence of Dissolved Organic Carbon. Environ. Sci. Technol. 2010, 44, 11, 4210-4216

BRUMSACK H.J. (2006). The trace metal content of recent organic carbon-rich sediments: Implications for Cretaceous black shale formation. Palaeogeogr. Palaeoclimatol. Palaeoecol. 232, 344-361.

BRUNNER B., BERNASCONI S. (2005) A revised isotope fractionation model for dissimilatory sulphate reduction in sulphate reducing bacteria. Geochim. Cosmochim. Acta 69, 4759-4771.

CAI, C.F., LI, H.T., QIN M.K., LUO, X.R., WANG, F.Y., OU, G.X. (2007). Biogenic and petroleum-related ore-forming processes in Dongsheng uranium deposit, NW China. Ore Geology Reviews 32, 262-274.

CAO, B.F., BAI, G.P., ZHANG, K.X., HE, B. (2016). A comprehensive review of hydrocarbons and genetic model of sandstone-hosted Dongsheng uranium deposit, Ordos Basin, China. Geofluids, 16, pp. 624-650.

CARDENAS, E., WU, W.M., BETH LEIGH, M., CARLEY. J., CARROLL, S., GENTRY, T., LUO, J., WATSON, D., GU, B., GIN DER-VOGEL, M., KITANIDIS, K.P., JARDINE, P.M., ZHOU, J., CRIDDLE, C.S., MARSH, T.L., TIEDJE, J.M. (2010). Significant Association between Sulfate-Reducing Bacteria and Uranium-Reducing Microbial Communities as Revealed by a Combined Massively Parallel Sequencing-Indicator Species Approach. Applied and Environmental Microbiology, 20, pp. 6778-6786; DOI: 10.1128/AEM.01097-10 
CARDON, O., LE GOUX, F., SALABERT, J. (2015). Prospection d'uranium en Mongolie: découverte majeure dans le désert de Gobi [Uranium exploration in Mongolia: important discovery in the Gobi Desert]. Revue Générale Nucléaire, vol. 47, pp. 12-19.

CAVALAZZI, B., AGANGI, A., BARBIERI, R., FRANCHI, F., \& GASPAROTTO, G. (2014). The formation of low-temperature sedimentary pyrite and its relationship with biologically-induced processes. Geology of Ore Deposits, 56(5), 395-408.

CHEBURKIN, A. and SHOTYK, W. (1996). An Energy-dispersive Miniprobe Multielement Analyzer (EMMA) for direct analysis of Pb and other trace elements in peats. Fresenius Journal of Analytical Chemistry, vol. 354, pp. 688-91.

CLARK, C., GRGURIC B., SCHMIDT, M.A. (2004). Genetic implications of pyrite chemistry from the Palaeoproterozoic Olary Domain and overlying Neoproterozoic Adelaidean sequences, northeastern South Australia. Ore Geology Reviews, 25, pp. 237-257.

CUMBERLAND, S.A., ETSCHMANN, B., BRUGGER, J., DOUGLAS, G., EVANS, K., FISCHER, L., KAPPEN, P., MOREAU, J.W. (2018). Characterization of uranium redox state in organic-rich Eocene sediments. Chemosphere, 194, pp. 602-613.

DAHLKAMP, F.J. (2009). Uranium Deposits of the World: Asia, Berlin Heidelberg: Springer-Verlag, 493 pp.

DESCOSTES, M., SCHLEGEL, M.L., EGLIZAUD, N., DESCAMPS, F., MISERQUE, F., SIMONI, E. (2010). Uptake of uranium and trace elements in pyrite (FeS 2 ) suspensions. Geochimica et Cosmochimica Acta, 74, pp. 1551-1562.

DETMERS J., BRÜCHERT V., HABICHT K. S., KUEVER J. (2001). Diversity of sulfur isotope fractionations by sulfate-reducing prokaryotes. Applied Environmental Microbiology, 67, pp. 888-894.

DOTT, R. H. JR. (1964). Wacke, greywacke and matrix-What approach to immature sandstone classification?. Journal of Sedimentary Petrology, vol. 34, No. 3. pp. 625-632.

DU, X., BOONCHAYAANANT, B., WEI-MIN, W., FENDORF, S., BARGAR, J., CRIDDLE, C.S. (2011). Reduction of Uranium(VI) by Soluble Iron(II) Conforms with Thermodynamic Predictions. Environmental Science \& Technology, American Chemical Society, 45, pp. 4718-4725.

EGLIZAUD, N., MISERQUE, F., SIMONI, E., SCHLEGEL, M.L., DESCOSTES, M. (2006). Uranium (VI) interaction with pyrite (FeS 2 ): chemical and spectroscopic studies. Migration 2005, Avignon, France, pp. 651-656. DOI : 10.1524/ract.2006.94.9-11.651

ESPITALIE, J., DEROO, G., MARQUIS, F. (1985). Rock-eval pyrolysis and its applications. Oil Gas Sci. Technol. -Rev IFP 40-6, 755-784. 
FORBES, P., LANDAIS, P., BERTRAND, P., BROSSE, E., ESPITALIÉ, J., YAHAYA, M. (1988). Chemical transformations of type-III organic matter associated with the Akouta uranium deposit (Niger): Geological implications. Chemical Geology, 71, pp. 267-282.

FOWLER, A.D., DOIG, R. (1983). The significance of europium anomalies in the REE spectra of granites and pegmatites, Mont Laurier, Quebec. Geochimica et Cosmochimica Acta, 47, pp. 1131-1137.

GÄCHTER, R., MEYER, J.S. (1993). The role of microorganisms in mobilization and fixation of phosphorus in sediments. Hydrobiologia, 253 , pp. $103-121$.

GADD, G.M. (1996). Influence of microorganisms on the environmental fate of radionuclides. Endeavour, 20, pp. 150-156.

GOLDSCHMIDT V. M. (1954). Geochemistry. The Clarendon Press, Oxford, p. 730.

GRAHAM, S.A., HENDRIX, M.S. JOHNSON, C.L., BADAMGARAV, D., BADARCH G., AMORY, J., PORTER, M., BARSBOLD, R., WEBB, L.E., and HACKER B.R. (2001). Sedimentary record and tectonic implications of Mesozoic rifting in southeast Mongolia. Geological Society of America Bulletin, vol. 113, pp. 1560-1579.

GRANGER, H.C.; WARREN, C.G. (1969). Unstable sulfur compounds and the origin of roll-front type uranium deposits. Economic Geology, 64 (2), pp. 160171.

GRIZARD, P., SCHMITT, J.M., GOBLET, P. (2018). Hydrogeology of an arid endorheic basin (Tsagaan Els, Dornogobi, Mongolia): field data and conceptualization, three-dimensional groundwater modeling, and water budget. Hydrogeology Journal, doi.org/10.1007/s10040-018-1868-1

GRUNER, J.W., GARDINER, L., SMITH, D.K (1953). Studies relating to the origin and distribution of uranium deposits on the Colorado Plateau. Annual Report for July 1, 1952 to March 31. Division of Raw Materials, Washington 25, D.C., 58 p.

HERRON, M.M. (1988). Geochemical classification of terrigenous sands and shales from core or log data: Journal of Sedimentary Petrology, v. 58, no.5, pp. $820-829$.

HEUMANN, J.M., JOHNSON, L.C., WEBB, L.E., TAYLOR, P.J., JALBAA, U., MINJIN, C. (2014). Total and left-lateral displacement across the East Gobi Fault Zone, southern Mongolia: Implications for timing and modes of polyphase intracontinental deformation. Earth and Planetary Science Letter (392), pp. $1-15$. 
HOLMES, D.E., ORELANA, R., GILOTEUAX, L., WANG, L.Y., SHRESTHA, P., WILLIAMS, K., LOVLEY, D.R., ROTARU, A.E. (2018). Potential for Methanosarcina to Contribute to Uranium Reduction during Acetate-Promoted Groundwater Bioremediation. Microbial Ecology, 76, pp. 660-667.

HOUGH, G., SWAPP, S., FROST, C., FAYEK, M. (2019). Sulfur Isotopes in Biogenically and Abiogenically Derived Uranium Roll-Front Deposits. Economic Geology, v. 114, no. 2, pp. 353-373.

HUA, B, XU, H., TERRY, J., DENG, G. (2006). Kinetics of Uranium(VI) Reduction by Hydrogen Sulfide in Anoxic Aqueous Systems. Environmental Science and Technology, 40, 4666-4671.

HUA, B., DENG, B. (2008). Reductive immobilization of uranium (VI) by amorphous iron sulfide. Environmental Science \& Technology, 42 , pp. $8703-8708$.

HUANG, W.H. (1978). Geochemical and Sedimentologic Problems of Uranium Deposits of Texas Gulf Coastal Plain. vol. 62, 6, pp. 1049-1062.

HUANG, XIAN-FANG., LIU, DE-CHANG., DU, LE-TIAN., ZHAO, YING-JUN. (2005). A new sandstone type uranium metallogenetic type-'structure-oil, gas type'. In: JINGWEN, M., BIERLEIN, F.P. (eds), Mineral Deposit Research: Meeting the Global Challenge. Proceedings of the Eighth Biennial SGA meeting, Beijing, China, August 2005, 265-268.

HUTCHENS, E., VALSAMI-JONES, E., HAROUIYA, N., CHAïRAT, C., OELKERS, E.H., McELDONEY, S. (2006). An Experimental Investigation of the Effect of Bacillus megaterium on Apatite Dissolution, Geomicrobiology, 23(3), pp. 177-182.

IDIZ, E.F., CARLISLE, D., KAPLAN, I.R. (1986). Interaction between organic matter and trace metals in a uranium rich bog, Kern County, California, U.S.A, Applied Geochemistry, 1, 573-590.

INGHAM, E.S., COOK, N.J., CLIFF, J., CIOBANU, C.L., HUDDLESTON, A. (2014). A combined chemical, isotopic and microstructural study of pyrite from rollfront uranium deposits, Lake Eyre Basin, South Australia. Geochimica et Cosmochimica Acta, 125, pp. 440-465.

INTERNATIONAL ATOMIC ENERGY AGENCY (IAEA) and NUCLEAR ENERGY AGENCY (NEA). (2018). Uranium 2018: Resources, production and Demand, NEA No. 7413, (C) OECD 2018, pp. 462.

INTERNATIONAL COMMITTEE FOR COAL PETROLOGY (ICCP), 1963. International Handbook of Coal Petrography, 2nd Edition. CNRS. Academy of Sciences of the USSR, Paris, Moscow. 
INTERNATIONAL COMMITTEE FOR COAL PETROLOGY, (ICCP), 1971. International Handbook of Coal Petrography, 1st Supplement to 2nd Edition. CNRS, Paris.

INTERNATIONAL COMMITTEE FOR COAL PETROLOGY, (ICCP), 1975. International Handbook of Coal Petrography, 2nd Supplement to 2nd Edition. CNRS, Paris.

INTERNATIONAL COMMITTEE FOR COAL AND ORGANIC PETROLOGY, (ICCP), 1998. The new vitrinite classification (ICCP System 1994). Fuel 77, $349-358$. INTERNATIONAL COMMITTEE FOR COAL AND ORGANIC PETROLOGY, (ICCP), 2001. The new inertinite classification (ICCP System 1994). Fuel 80, $459-471$.

ITTERBEECK, J.V., HORNE, D.J., BULTYNCK, P., VANDENBERGHE, N. (2005). Stratigraphy and palaeoenvironment of the dinosaur-bearing Upper Cretaceous Iren Dabasu Formation, Inner Mongolia, People's Republic of China, Cretaceous Research, Volume 26, Issue 4, August 2005, pp. 699-725.

JAIRETH, S., McKAY, A., LAMBERT, I. (2008). Association of large sandstone uranium deposits with hydrocarbons. Australian Government, Geoscience Australia, 89, $6 \mathrm{p}$.

JARAULA, C.M.B., SCHWARK, L., MOREAU, X., PICKEL, W., BAGAS, L., GRICE, K. (2015). Radiolytic alteration in the Mugla Rock (Australia) uranium deposit. Applied Geochemistry, vol. 52, pp. 97-108.

JERZYKIEWICZ, T., RUSSELL, D.A. (1991). Late Mesozoic stratigraphy and vertebrates of the Gobi Basin. Cretaceous Research, 12, pp. 345-377.

JIAO, Y.Q., WU, L.Q., RONG, H., ZHANG, F., YUE, L., TAO, Z.P., SUN, Y.H. (2018). Geological modeling of uranium reservoir: The geological foundation of revealing the metallogenic mechanism and solving "Remaining Uranium". Earth Science 43, 3568-3583 (in Chinese with English abstract).

JOHNSON, C.L. (2004). Polyphase evolution of the East Gobi basin: sedimentary and structural records of Mesozoic-Cenozoic intraplate deformation in Mongolia. Basin Research (16), 79-99.

JOHNSON, C.L. and RITTS, B.D. (2012). Plate interior poly-phase basins. In: BUSBY, C. and AZOR PEREZ, A. (2012). Tectonics of Sedimentary Basins: Recent Advances. Wiley, Hoboken, ISBN: 9781444347135, pp. 567-582.

KITAYAMA, Y., THOMASOT, E., O'NEIL, J., WING, B. (2012). Sulfur-and oxygen-isotopes, constraints on the sedimentary history of apparent conglomerates from the Nuvvuaggittuq Greenstone Belt (Nuvanik, Quebec). Earth and Planetary Science Letters, 355, pp. 271-282. 
KOCHENOV, A.V., KOROLEV, K.G., DUBINCHUK, V.T., MEDVEDEV, Y.L. (1977). Experimental data on precipitation of uranium aqueous solution. Geochemistry International, 14, pp. 82-87.

LACH, P., CATHELINEAU, M., BROUAND, M., FIET, N. (2015). In-situ isotopic and chemical study of pyrite from Chu-Sarysu (Kazakhstan) roll-front uranium deposit. Procedia Earth and Planetary Science, 13, pp. 207-210. doi.org/10.1016/j.proeps.2015.07.049

LAMB, M.A. and BADARCH, G. (1997): Paleozoic sedimentary basins and volcanic-arc systems of southern Mongolia: New stratigraphic and sedimentologic constraints: International Geology Review, v. 39, p. 542-576.

LANDAIS, P., CONNAN, J., DEREPPE, J.M., GEORGE, E., MEUNIER, J.D., MONTHIOUX, M., PAGEL, M., PIRONON, J., POTY, B. (1987). Alterations of the organic matter, a clue for uranium ore genesis. Uranium, 3, 307-342.

LANDAIS, P. (1996). Organic geochemistry of sedimentary uranium ore deposits. Ore Geol. Reviews, 11, pp. 33-51.

LE GOUX, F., BANZRAGCH, T.O., DELAUNAY A., NYAMDORJ, B.I., JAQUES, E., KORSHUNOV, A., PARIZE, O. and BROUAND, M. (2015). The Major Gobi Uranium Deposits, Upper Cretaceous East Gobi Basin, Mongolia: Geodynamical and Mineralogical Key Parameters of Uranium Ore Geology. In: Mineral Resources in a Sustainable World, 13th SGA Biennial Meeting 2015, vol. 5, 1815-1818.

LONGERICH H.P., JACKSON S.E. and GÜNTHER D. (1996). Laser Ablation Inductively Coupled Plasma, Mass Spectrometric Transient Signal Data Acquisition and Analyte Concentration Calculation. Journal of Analytical Atomic Spectrometry, vol. 11, p. 899-904.

LOVLEY, D.R., PHILLIPS, E.J.P., GORBY, Y. A., LANDA, E.R. (1991). Microbial reduction of uranium. Nature, 350, pp. 413-416. doi:10.1038/350413a0

LOVLEY, D.R., RODEN, E.E., PHILLIPS, E.J.P., WOODWARD, J.C. (1993). Enzymatic iron and uranium reduction by sulfate-reducing bacteria. Marine and Petroleum Geology, 113, pp. 41-53.

LOWERS, H.A., BREIT, G.N., FOSTER, A.L., WHITNEY, J., YOUNT, J., UDDIN, M.N., MUNEEM, A. (2007). Arsenic incorporation into authigenic pyrite, Bengal Basin sediment, Bangladesh. Geochimica et Cosmochimica Acta, 71, pp. 2699-2717.

MACLEAN, L.C.W., TYLISZCZAK, T., GILBERT, P.U.P.A., ZHOU, D., PRAY, T.J., ONSTOTT, T.C., SOUTHAM, G. (2008). A high-resolution chemical and structural study of framboidal pyrite formed formed within a low-temperature bacterial biofilm. Geobiology, 6(5), pp. 471-480. https://doi.org/10.1111/j.14724669.2008.00174.x 
MAKHNACH, A., MIKHAJLOV, N., KOLOSOV, I., GULIS, L., SHIMANOVICH, V., DEMENEVA, O. (2000). Comparative analysis of sulfur isotope behavior in the basins with evaporites of chloride and sulfate types. Sedimentary Geology, 134, pp. 343-360.

MASUDA A., NAKAMURA N., and TANAKA T. (1973). Fine structure of mutually normalized rare-earth patterns of chondrites, Geochimica et Cosmochimica Acta, 37, pp. 239-248.

MENOR-SALVAN C., TORNOS, F., FERNANDEZ-REMOLAR, D., AMILS, R (2010). Association between catastrophic paleovegation changes during DevonianCarboniferous boundary and the formation of giant massive sulfide deposits. Earth and Planetary Science Letters, doi:10.1016/j.epsl.2010.09.020.

MERCADIER, J., CUNEY, M., LACH, P., BOIRON, M.C., BONHOURE, J., RICHARD, A., LEISEN, M., KISTER, P. (2011). Origin of uranium deposits revealed by their rare earth element signature. Terra Nova, 23, No.4, pp.264-268.

MEUNIER, J.D., SELLIER, E., PAGEL, M., (1990a). Radiation damage rims in quartz from uranium bearing sandstones. Journal of Sedimentary Petrology, 60, pp. 53-58.

MEUNIER, J.D., LANDAIS, P., PAGEL, M. (1990b). Experimental evidence of uraninite formation from diagenesis of uranium rich organic matter. Geochimica et Cosmochimica Acta, 54, pp. 809-817.

MEYERHOFF, A.A. and MEYER, R.F. (1987). Geology of heavy crude oil and natural bitumen in the USSR, Mongolia, and China. In: MEYER, R. F, ed., Exploration for heavy crude oil and natural bitumen: AAPG Studies in Geology 25, pp. 31-101.

MIN, M., XU, H., CHEN, J., FAYEK, M. (2005). Evidence of uranium biomineralization in sandstone-hosted roll-front uranium deposits, northwestern China, Ore Geology Reviews, Volume 26, Issues 3-4, July 2005, pp. 198-206.

MUNARA, A. (2012). Formation des gisements d'uranium de type roll : approche minéralogique et géochimique du gisement uranifère de Muyunkum (Bassin de Chu-Sarysu, Kazakhstan). Thèse soutenue le 9 Juillet 2012, PhD Univ. H. Poincaré Nancy. 327p.

MUROWCHICK, J. B., \& BARNES, H. L. (1986). Marcasite precipitation from hydrothermal solutions. Geochimica et Cosmochimica Acta, 50(12), 2615-2629.

NAKASHIMA, S., DISNAR, J.R., PERRUCHOT, A., TRICHET, J. (1984). Experimental study of mechanisms of fixation and reduction of uranium by sedimentary organic matter under diagenetic or hydrothermal conditions. Geochimica et Cosmochimica Acta, 48, pp. $2321-2329$.

NAKASHIMA, S. (1992). Complexation and reduction of uranium by lignite. Science of the Total Environnent, 117-118, pp. $425-437$. 
NIU, L., HUANG, S., YANG, G. (1995). The characteristics of uranium mineralization and genesis of Nuheting uranium deposit in Erlian Basin, Inner Mongolia.

China Nucl. Sci. Technol. Rep. 1995-00 (in Chinese with English abstract).

OWEN D.E., OTTON J.K. (1995). Mountain wetlands: efficient uranium filters-potential impacts. Ecological Engineering, 5, pp. 77-93.

PARIZE, O. (2013). Le remplissage de la dépression de Tsagaan Els et les dépôts fluviatiles associés (Crétacé moyen, Bassin de Zuunbayan). Implication stratigraphiques et sédimentologiques sur le gisement de Zoovch Ovoo - Synthèse des résultats 2012-2013. Octobre 2013, édition décembre 2014. Rapport technique AMS-DGS-TEC-SDYRT-0008, (Poster AMS-DGS-TEC-SDY-RT-0008_PosterZoovchA1_2013).

PARIZE, O. (2015). Le remplissage de la dépression de Tsagaan Els et les dépôts fluviatiles associés (Crétacé moyen, Bassin de Zuunbayan). Implication stratigraphiques et sédimentologiques sur le gisement de Zoovch Ovoo - Synthèse des résultats 2012-2013. Octobre 2013, édition décembre 2014. Rapport technique AMS-DGS-TEC-SDYRT-0008, (Poster AMS-DGS-TEC-SDY-RT-0008_PosterZoovchA1_2013).

PEARCE N.J.G., PERKINS W.K., WESTGATE J.A., GORTON M.P., JACKSON S.E., NEAL C.R. AND CHENERY S.P. (1997). A compilation of new and published major and trace element data for NIST SRM 610 and NIST SRM 612 glass reference materials. Geostandards and Geoanalytical Research, vol. 21, pp. 101114.

PETROV N.N. (1998). Les gisements épigénétiques du Kazakhstan. Géologie du Kazakhstan, 2(354): pp. 22-39. (trans. from Russian).

PICARD, A., GARTMAN, A., CLARKE, D.R., GIRGUIS, P.R. (2017). Sulfate-reducing bacteria influence the nucleation and growth of mackinawite and greigite. Geochimica et Cosmochimica Acta. doi.org/10.1016/i.gca.2017.10.006

PICKEL, W., KUS, J., FLORES, D., KALAITZIDIS, S., CHRISTANIS, K., CARDOTT, B.J., MISZ-KENNAN, M., RODRIGUES, S., HENTSCHEL, A., HAMOR-VIDO, M., CROSDALE, P., WAGNER, N. (2017). Classification of liptinite - ICCP System 1994. International Journal of Coal Geology, 169, pp. 40-61.

PROST, G.L. (2004). Tectonics and hydrocarbon systems of the East Gobi basin, Mongolia, AAPG Bulletin, vol. 88, No. 4, pp. 483-513.

RACKLEY, R.I. (1972). Environment of Wyoming Tertiary Uranium Deposits. The American Association of Petroleum Geologists Bulletin, v. 56. No. 4. Pp. 755774.

RALLAKIS, D., MICHELS, R., BROUAND, M., PARIZE, O., CATHELINEAU, M. (2019). The Role of Organic Matter on Uranium Precipitation in Zoovch Ovoo, Mongolia. Minerals 9(5), 310. DOI: 10.3390/min9050310 
RALLAKIS, D., MICHELS, R., BROUAND, M., PARIZE, O., CATHELINEAU, M. (2020). Dolomite cements in Cenomanian continental sand deposits: time evolution and significance (Zoovch Ovoo U-deposit, East Gobi Basin, Mongolia). Sedimentary Geology, vol. 405(C), 105688. doi.org/10.1016/j.sedgeo.2020.105688

REYNOLDS, R.L., GOLDHABER, M.B. (1978). Origin of a South Texas roll-type uranium deposit; I, Alteration of iron-titanium oxide minerals. Economic Geology, 73(8): 1677-1689.

ROUZAUD, J.N., OBERLIN, A., TRICHET, J. (1980). Interaction of uranium and organic matter in uriniferous sediments. Physics and Chemistry of the Earth, vol. 12, pp. 505-516.

SAVAGE, K.S., TINGLE, T.N., O'DAY, P.A., WAYCHUNAS, G.A., BIRD, D.K. (2000). Arsenic speciation in pyrite and secondary weathering phases, Mother Lode Gold District, Tuolumne County, California. Applied Geochemistry, 15, pp. 1219-1244.

SAWLOWICZ, Z. (1993). Pyrite framboids and their development: a new conceptual mechanism. Geologische Rundschau, 82(1), pp. 148-156.

SAWLOWICZ, Z. (2000). Framboids: from their origin to application. Polska Akademia Nauk - Oddział W Krakowie, Prace Mineralogiczne, 88,80 pp.

SCHULZ, H.M., YANG, S., PANOVA, E., BECHTEL, A. (2018). The role of Pleistocene meltwater-controlled uranium leaching in assessing irradiation-induced alteration of organic matter and petroleum potential in the Tremadocian Koporie Formation (Western Russia), Geochimica et Cosmochimica Acta, doi: https:// doi.org/10.1016/j.gca.2018.10.029

SCHWERTMANN, U. (1991). Solubility and dissolution of iron oxides. Plant and soil, 130, pp. 1-25.

SEIBERT, S., DESCOURVIERES, C., SKRZYPEK, G., DENG, H., PROMMER, H. (2017). Model-based analysis of $\delta^{34}$ S signatures to trace sedimentary pyrite oxidation during managed aquifer recharge in a heterogeneous aquifer. Journal of Hydrology, 548, pp. 368-381. https://doi.org/10.1016/j.jhydrol.2017.02.030

SPIRAKIS, C. (1996). The role of organic matter in the formation of uranium deposits in sedimentary rocks. Ore Geology Reviews, 11 , pp. 53-69.

STUMM, W., LEE, G.F. (1960). The chemistry of aqueous iron. Schweizerische Zeitschrift für Hydrologie, 22(1), pp. $295-319$.

SUÁREZ-RUIZ, I., FLORES, D., MENDONÇA FILHO, J.G., HACKLEY, P.C. (2012). Review and update of the applications of organic petrology: Part 1, geological applications. International Journal of Coal Geology, 99, pp. 54-112. 
SUZUKI, Y., BANFIELD, J.F. (1999). Geomicrobiology of Uranium, chapter 8. In: Burns, P.C., Finch, R. (1999). URANIUM: Mineralogy, Geochemistry and the Environment, Reviews in Mineralogy, 38, 673 p.

SÝKOROVÁ, I., PICKEL, W., CHRISTIANIS, K., WOLF, M., TAYLOR, G.H., FLORES, D., 2005. Classification of huminite-ICCP System 1994. International Journal of Coal Geology 62, 85-106.

TRAYNOR, J.J. and SLADEN, C. (1995). Tectonic and stratigraphic evolution of the Mongolian People's Republic and its influence on hydrocarbon geology and potential: Marine and Petroleum Geology, v. 12, p. 35-52.

VEERAMANI, H., SCHEINOST, A.C, MONSEGUE, N., OAFOKU, N.P., KUKKADAPU, R., NEWVILLE, M., LANZIROTTI, A., PRUDEN, A., MURAYAMA, M., HOCHELLA, Jr. M.F. (2013). Abiotic Reductive Immobilization of U(VI) by Biogenic Mackinawite. Environmental Science and Technology, 47, 5, $2361-2369$.

WARWICK, P., EVANS, N., HALL, A., WALKER, G., STEIGLEDER, E. (2005). Stability constants of U(VI) and U(IV)-humic acid complexes. Journal of Radioanalytical and Nuclear Chemistry, 266(2), pp. 179-190.

WATSON, J., CRESSEY, B., ROBERTS, A., ELLWOOD, D., CHARNOCK, J., AND SOPER, A. (2000). Structural and magnetic studies on heavy-metal-adsorbing iron sulphide nanoparticles produced by sulphate-reducing bacteria. J. Magn. Magn Mater. 214 (1-2), 13-30. doi:10.1016/s0304-8853(00)00025-1

WENTWORTH, C.K. 1922. A scale of grade and class terms for clastic sediments. Journal of Geology. 30:377-392.WORDEN, R.H. \& BURLEY, S.D. (2003). Sandstone diagenesis: the evolution of sand to stone, Sandstone Diagenesis: Recent and Ancient. International Association of Sedimentologists, 44 pp. ISBN: 978-405-10897-3.

WERSIN, P., HOCHELLA, M.F., PERSSON, P., REDDEN, G., LECKIE, J.O., HARRIS, D.W. (1994). Interaction between aqueous uranium (VI) and sulfide minerals: Spectroscopic evidence of sorption and reduction. Geochimica et Cosmochimica Acta, 58(13), pp. 2829-2843.

WILKINS, M.J., LIVENS, F.R., VAUGHAN, D.J., LLOYD, J.R. (2006). The impact of Fe(III)-reducing bacteria on uranium mobility. Biogeochemistry, 78(2), pp. $125-150$.

WOLTHERS, M., VAN DER GAAST, S. J., AND RICKARD, D. (2003). The structure of disordered mackinawite. Am. Mineral. 88 (11-12), 2007-2015. doi:10.2138/am-2003-11-1245 
YUE, L., JIAO, Y., Wu, L., RONG, H., XIE, H., WANG, Q., YAN, Q. (2019). Selective crystallization and precipitation of authigenic pyrite during diagenesis reservoir sandbodies in Ordos Basin. Ore Geology Reviews, vol. 107, pp. 532-545.

ZHANG, R., DING, W. (1996). Discussion on geological characteristics of Nuheting type uranium deposit and the relation between oil and gas-bearing water and uranium metallogenesis. Galaxy of Research Achievements of Uranium Geology of China. Bureau of Geology, CNNC, Beijing, pp. 205-214.

ZHANG, F., JIAO, Y.Q., WU, L.Q., RONG, H., WANG, L.H. (2018). Relations of uranium enrichment and carbonaceous debris within the Daying uranium deposit, northern Ordos Basin. Journal of Earth Science, DOI: 10.1007/s12583-017-0952-0.

ZHANG, F., JIAO, Y., WU, L., RONG, H., WANG, L., ZHANG, Z. (2019). In-situ analyses of organic matter maturation heterogeneity of uranium-bearing carbonaceous debris within sandstones: A case study from the Ordos Basin in China, Ore Geology Reviews, doi: https://doi.org/10.1016/j.oregeorev.2019.03.021

ZHU, M., WU, R., LIU, X., NIE, F., YU, D. (2012). Geologic Setting of Interformational Braided Channel Type Sandstone Uranium Deposits in North China, East China Institute of Technology, 29/05/2012 IAEA Conference, PowerPoint Presentation. Available online from: https://www.slideshare.net/monatom/05-xiaodong-liu-geologic-setting-of-interformationalbraidedchannel-type-sandstone-uranium-deposits-innorth-china

\section{FIGURES}

Figure 1: Location map of Mongolia presenting A) the four metallogenic provinces hosting $U$, namely from North to South 1) North Mongolian, 2) Khentai-Daur, 3) Mongol-Priargun, 4) Gobi-Tamtsag (Dahlkamp, 2009); B) the study area and C) a simplified geological map of East Gobi Basin with the morpho-tectonic elements. The Zoovch Ovoo roll-front $U$ deposit is located in the Zuunbayan sub-basin in East Hongor Tolgoy and Bayanshiree plateau (map modified from Graham et al., 2001). 
Figure 2: Stratigraphical column of the East Gobi Basin, including potential unconformities, depositional environments and tectonic episodes. Modified from Jerzykiewicz and Russell (1991); Prost (2004). 1= metamorphic rocks, $2=$ granitic rocks, $3=$ conglomerate, $4=$ coarse sandstone, $5=$ medium sandstone, $6=$ shale, $7=$ uncertain duration, $8=$ Zoovch Ovoo uranium deposit.

Figure 3: Examples of studied samples distribution (green and blue dots for U-rich and carbonate cemented samples, respectively) along with two roll-front profiles. The background colours represent oxidized (yellow) versus reduced sand (white), clays (green) and uranium mineralization (red mesh texture). The vertical lines represent drilling-wells. The two profiles are not on the same vertical scale. The distance between wells is at the scale of tens of meters.

Figure 4: Examples of typical core sequences in Zoovch Ovoo. A) Well, ZOOV_1142, depth $306.20 \mathrm{~m}$. From left to right: reduced matrix-supported sandstone, oxidized matrix-supported sandstone, reduced matrix-supported sandstone with organic matter, and reduced carbonate cemented sandstone. B) Well, ZOOV_1154, depth $164.10 \mathrm{~m}$. Reduced (left) and oxidized (right) consolidated facies ranging from silty claystone to very fine sand.

Figure 5: Summary of the main siliciclastic and carbonate elements presented in the Zoovch Ovoo sands. (A, B) Monocrystalline and polycrystalline quartz. (C, D) Plagioclase and microcline with polysynthetic and cross-hatched twinning, respectively. The plagioclase with slight sericite alteration. (E, F) Detrital muscovite, chlorite, biotite. (G) Detrital dolomite grain, (H) Lithic element showing granophyric texture. All photographs under polarized/analyzed light; $(G)$ under white light.

Figure 6: Conceptual drawings of the five $\mathrm{FeS}_{2}$ generations identified in the Zoovch Ovoo sands. From left to right moving from the older to the younger generation: i) framboidal; ii) concentric (overgrowth); iii) euhedral pyrite 1 (pre-ore), iv) acicular FeS $\mathrm{S}_{2}$ (marcasite) and v) euhedral pyrite 2 (ore-stage.

Figure 7: Examples of the uranium ore replacing the euhedral pyrite 1 (pre-ore) generation while crystallized contemporaneously with the euhedral pyrite 2 (ore-stage). All pictures are taken under SEM-EDS using back-scattered electron mode. The uranium 
content is higher in the brighter zones. A) A close view showing the corrosion features of pyrite 1 as cement (pre-ore) systematically in contact with $\mathrm{UO}_{2}$. Quartz cement post-dates $\mathrm{UO}_{2}$; (B) In the lower half of the picture, detrital grains cemented by pyrite and $\mathrm{UO}_{2}$. Note the corroded surface of pyrite, which is also the boundary to $\mathrm{UO}_{2}$. In the upper half of the picture, matrix (clays) supported sandstone without $\mathrm{UO}_{2}$; (C) Framboidal pyrite with pyrite overgrowth followed by $\mathrm{UO}_{2}$ rim and euhedral pyrite 2 (ore stage). The whole cluster is encompassed by uranium-rich clay matrix; (D) Zoomed image of (C), where the two pre-ore stage pyrite generations (framboidal pyrite and overgrowth) can be discriminated by the ore-stage euhedral pyrite 2 , separated by a UO $\mathrm{O}_{2}$ coating; (E) An organic matter particle relic (encompassed by the yellow dotted line) that was previously replaced by framboidal pyrite. The framboids are closely packed to form pyrite cement. Eventually, pyrite cement is being replaced by uranium (uraninite). The contact between uraninite and remaining pyrite shows a typical contorted feature suggesting replacement process; (F) Focus on the contact between framboidal pyrite and $\mathrm{UO}_{2}$. Several rates of framboid replacement by $\mathrm{UO}_{2}$ are recognized from right to left: fully preserved framboids, framboid core remnants within $\mathrm{UO}_{2}$, almost entirely replaced framboid and finally $\mathrm{UO}_{2}$ cement without any recognizable pyrite; (G) Telovitrinite particle with variable uranium content and no observable U-mineral expression. The uranium content is higher in the brighter zones; $(\mathbf{H})$ Uranium as uraninite $\left(\mathrm{UO}_{2}\right)$ precipitating at the rims of a Collotelinite particle. Uranium concentration is decreasing towards the inner part of the particle as a function of increasing distance from the $U$-cement area;

Figure 8: Co and Cd content of pyrite as measured by La-ICPMS. It is possible to distinguish pyrite associated with uranium (in red circles) enriched in Co and Cd from pyrite not linked to uranium (in grey squares), which is depleted. Euhedral pyrite associated with marcasite (blue triangles) is enriched in $\mathrm{Cd}$, while the euhedral pyrite associated with sphalerite (green rhombs) enriched in Co. 
Figure 9: Frequency histogram presenting the distribution of $\delta^{34} S$ for the different iron disulfide occurrences: framboidal pyrite (in blue), euhedral/cubic pyrite (in red), framboidal pyrite replacing organic matter (in green), euhedral/cubic to anhedral FeS ${ }_{2}$ cement replacing organic matter (in purple) and marcasite.

Figure 10: The Rayleigh fractionation model of framboidal pyrite at Lost Creek (LC) from Hough et al., 2019 (blue dots), crossplotted with the results of this study (red dots) and pyrite data from Bonnetti et al., 2020 (green dots). The dashed line models $\delta^{34} S$ value of sulfate in solution with progressive sulfur depletion. The solid black line is the $\delta^{34} S$ value of pyrite produced at a specific level of depletion. According to the authors, the data corresponds to $88.5 \%$ depletion of sulfate in solution. The fractionation from Lost Creek is higher by about $100 \%$ than Zoovch Ovoo.

Figure 11: Summary of the macerals identified in the Zoovch Ovoo sands. Polished block photomicrographs under oil-immersion (x50) and reflected light. A) Fusinite with framboidal pyrite; B) Telovitrinite associated with euhedral pyrite and semifusinite; C) Very oxidized particle of telovitrinite (collotelinite); D) Fusinite containing uranium minerals, also euhedral pyrite, showing significantly higher reflectance.

Figure 12: The different forms of uranium petrographic types. (A) Uranium crystals as small spheres (U-balls) on organic matter (O.M). The maceral gelovitrinite (completely filled cells) appears to be more resilient to its replacement by $U$. (B) Elongated $U$ crystals termed U-flakes and U-aggregates. (C) U-balls of $1 \mu \mathrm{m}$ size inside sphalerite cement. (D) U-flakes are growing at the rim of a quartz grain.

Figure 13: Ternary plot of $\mathrm{P}_{2} \mathrm{O}_{5}-\mathrm{UO}_{2}-\mathrm{SiO}_{2}$ (in wt\% oxide) indicating the stoichiometric U-mineral compositions (striped squares) Uraninite, Phosphorus enriched Uraninite, Coffinite and Phospho-coffinite.

Figure 14: SEM-EDS analysis of a telovitrinite particle from sample 9704-8 (clay and organic matter intraclast in very coarsegrained mineralized sand). Three macerals can be discriminated, telinite, collotelinite and gelovitrinite. (A) Point measurements 
across the particle focusing on the areas of different brightness. The uranium content is uniformly fluctuating between 7.9-13.1 $w t \% .(B, C)$ High magnification of the bright regions of the telohuminite particle. Uranium distribution is not uniform at this scale.

Figure 15: The complete paragenesis of the diagenetic phases encountered in the Zoovch Ovoo sands.

Figure 16: Abiogenic redox model for pyrite dissolution and uranium reduction. (a) Pyrite is first partially dissolved; (b) Uranium is reduced from reduced sulfur and (c) by reduced iron.

Figure 17: The proposed metallogenic model for uranium formation and associated diagenetic phases in Zoovch Ovoo. The overall thickness of the reservoir has a maximum of $100 \mathrm{~m}$. The oxidization part of the roll front provides sulfates (inspired by Rackley, 1972) and micro-organisms. In the suboxic part of the roll-front, three major intricate processes are involved in the mineralization formation: 1. Sulfate (bio)reduction leading to pyrite formation, 2. Pyrite epigenesis by uraninite 3. Organic matter reactivity through complexation and sustainment of biological activity, responsible for uranium precipitation. Titanium oxide epigenesis by uraninite is also a common feature at Zoovch Ovoo. Organic matter sustains biological activity, which controls uranium precipitation either directly or through pyrite formation. It plays, therefore, a significant role in the biogeochemical process of uranium ore formation of Zoovch Ovoo. 


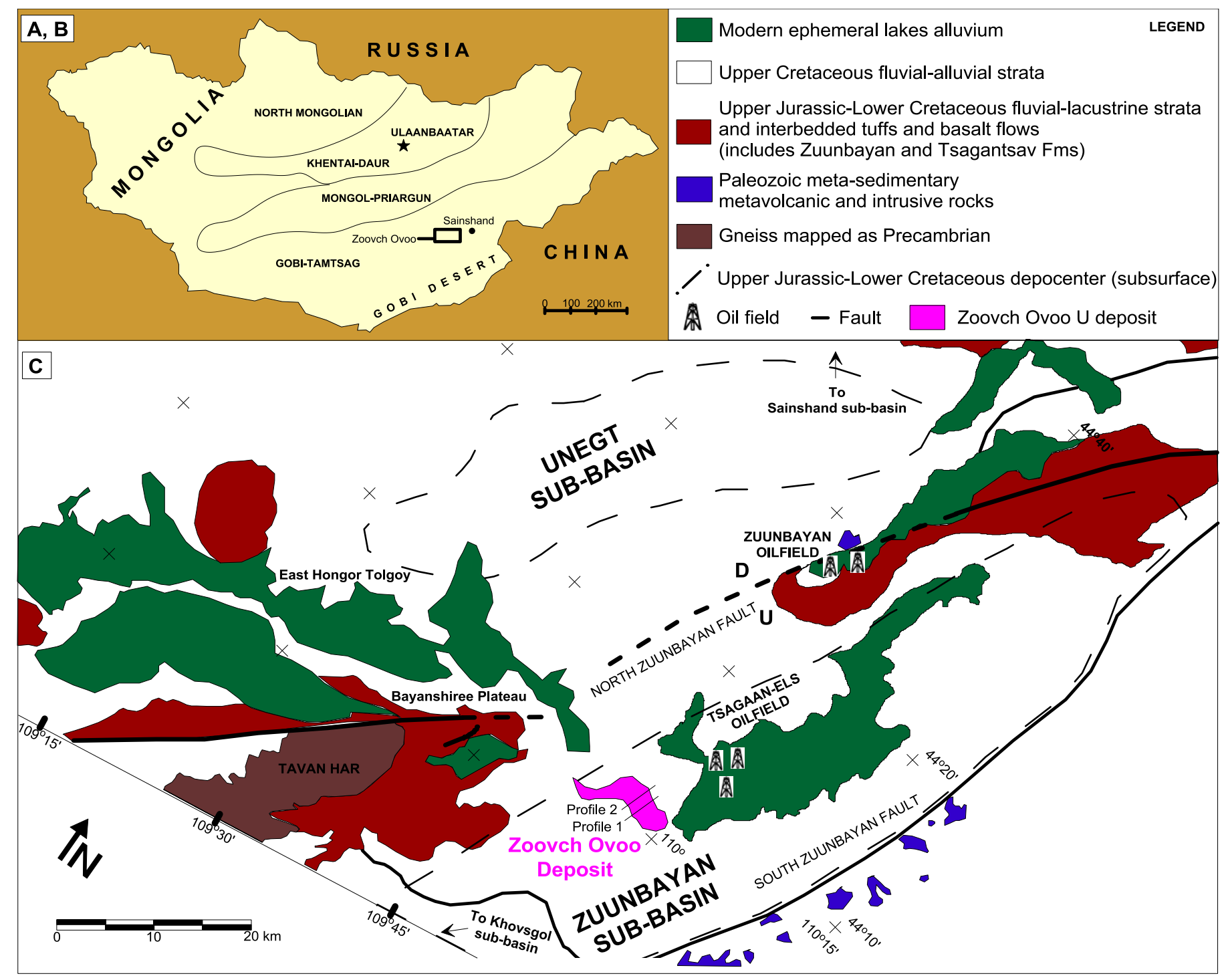

Figure 1 


\begin{tabular}{|c|c|c|c|c|c|c|c|c|}
\hline Era & Period & Stage & $\begin{array}{c}\text { Unit } \\
\text { (Formation) }\end{array}$ & $\begin{array}{l}\text { Thickness } \\
(\mathrm{m})\end{array}$ & $\begin{array}{l}\text { Age } \\
\text { (mya) }\end{array}$ & Lithology & $\begin{array}{l}\text { Sedimentary } \\
\text { Environment }\end{array}$ & $\begin{array}{l}\text { Tectonic } \\
\text { Stage }\end{array}$ \\
\hline \multicolumn{3}{|c|}{ Quaternary } & Undifferentiated & $0-140$ & $2.59-66.0$ & & Alluvial fans & \\
\hline \multirow{8}{*}{ 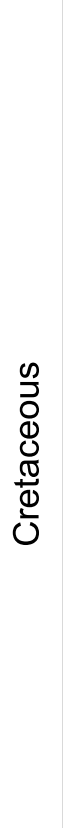 } & \multirow{4}{*}{$\stackrel{0}{\varpi}$} & $\begin{array}{c}\text { Maastricthian } \\
\text { Campanian }\end{array}$ & Nemegt & $0-310$ & $66.0-83.6$ & & $\begin{array}{l}\text { Ephemeral } \\
\text { meandering }\end{array}$ & Ð \\
\hline & & $\begin{array}{l}\text { Campanian } \\
\text { Santonian }\end{array}$ & Baruungoyot & $0-130$ & $83.6-86.3$ & & $\begin{array}{l}\text { Eolian } \\
\text { Ephemeral } \\
\text { meandering }\end{array}$ & 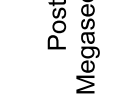 \\
\hline & & $\begin{array}{l}\text { Santonian } \\
\text { Turonian }\end{array}$ & Bayanshiree & $200-230$ & $86.3-93.9$ & & $\begin{array}{l}\text { Meandering } \\
\text { stream }\end{array}$ & \\
\hline & & Cenomanian & $\begin{array}{l}\text { Sainshand or } \\
\text { Baruunbayan }\end{array}$ & $170-350$ & 100.5 & & $\begin{array}{l}\text { Alluvial fan } \\
\text { Braided stream } \\
\text { Lacustrine }\end{array}$ & \\
\hline & \multirow{4}{*}{ 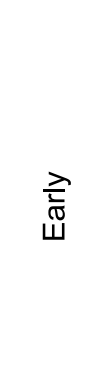 } & $\begin{array}{l}\text { Albian } \\
\text { Aptian }\end{array}$ & Upper & \multirow{3}{*}{$950-1000$} & \multirow[t]{3}{*}{$\begin{array}{l}113.0 \\
126.3\end{array}$} & & & Inversion \\
\hline & & Barremian & $\stackrel{0}{\frac{0}{5}}$ Lower & & & & Lacustrine & Ð \\
\hline & & Hauterivian & Bituminous & & & & & 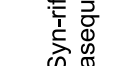 \\
\hline & & Valanginian & Tsagaan Tsav & $\sim 200$ & 139.4 & 17.7. & $\begin{array}{l}\text { Alluvial fan } \\
\text { Braided stream } \\
\text { Lacustrine }\end{array}$ & $\stackrel{\infty}{\Sigma}$ \\
\hline \multirow{2}{*}{$\begin{array}{l}\frac{0}{9} \\
0 \\
\frac{0}{0} \\
3\end{array}$} & 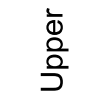 & $\begin{array}{c}\text { Tithonian } \\
\text { Kimmeridgian }\end{array}$ & Sharlyn & $\sim 200$ & $\begin{array}{l}145.0 \\
157.3\end{array}$ & 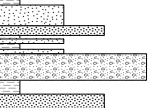 & $\begin{array}{l}\text { Fluvial } \\
\text { Lacustrine }\end{array}$ & 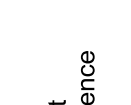 \\
\hline & $\frac{\frac{0}{D}}{\frac{0}{2}}$ & Bathonian & Khamar Khoovor & $\sim 750$ & 163.5 & & $\begin{array}{l}\text { Marginal } \\
\text { Marine }\end{array}$ & 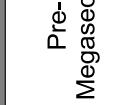 \\
\hline \multicolumn{2}{|c|}{ Permian } & Devonian & Tavan Tolgoy & Basement & & & $\begin{array}{l}\text { Metamorphic } \\
\text { rocks }\end{array}$ & anite \\
\hline & 1 & 2 & 3 & 4 & 5 & 6 & 7 & 岁 \\
\hline
\end{tabular}

Figure 2 


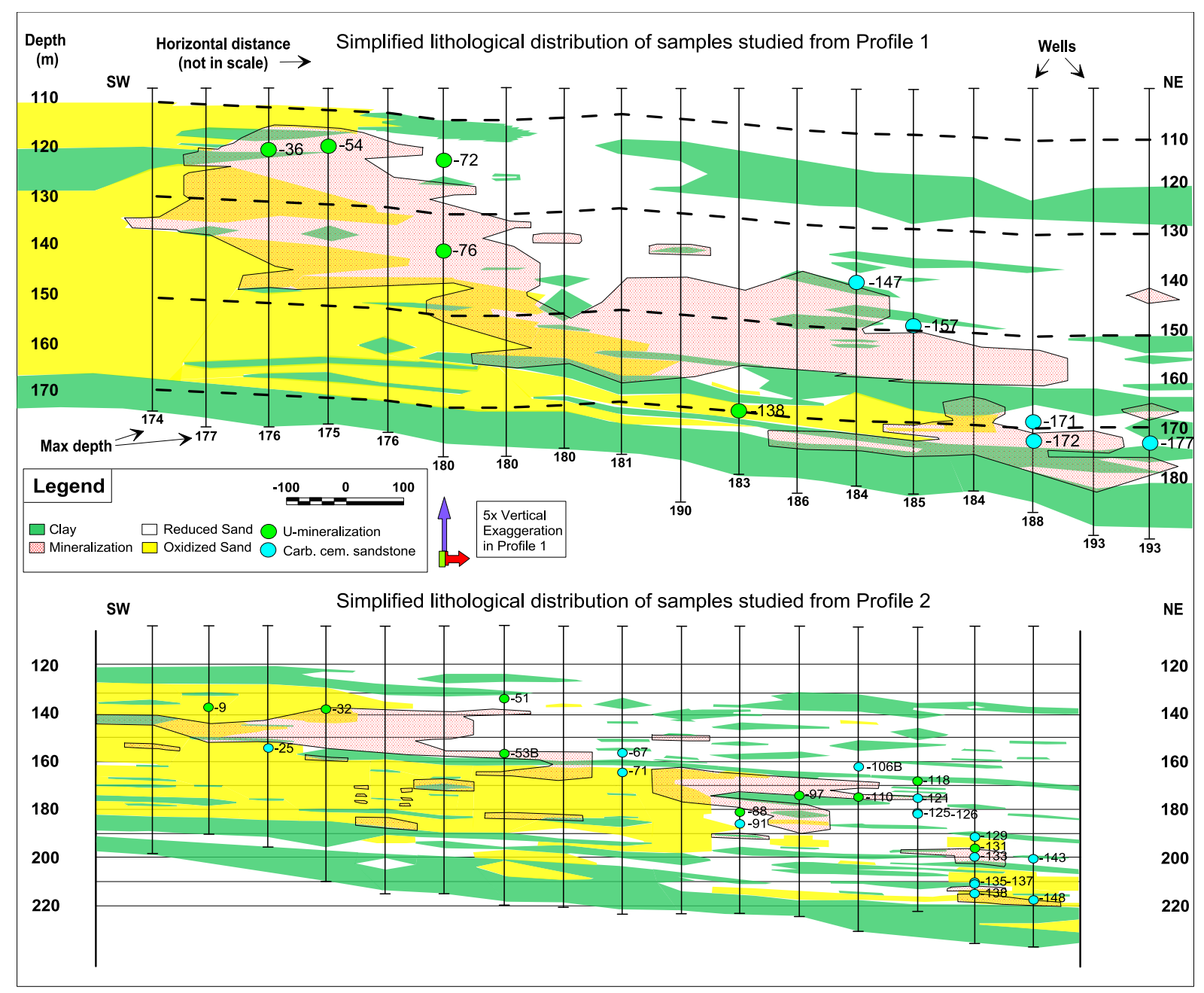

Figure 3 

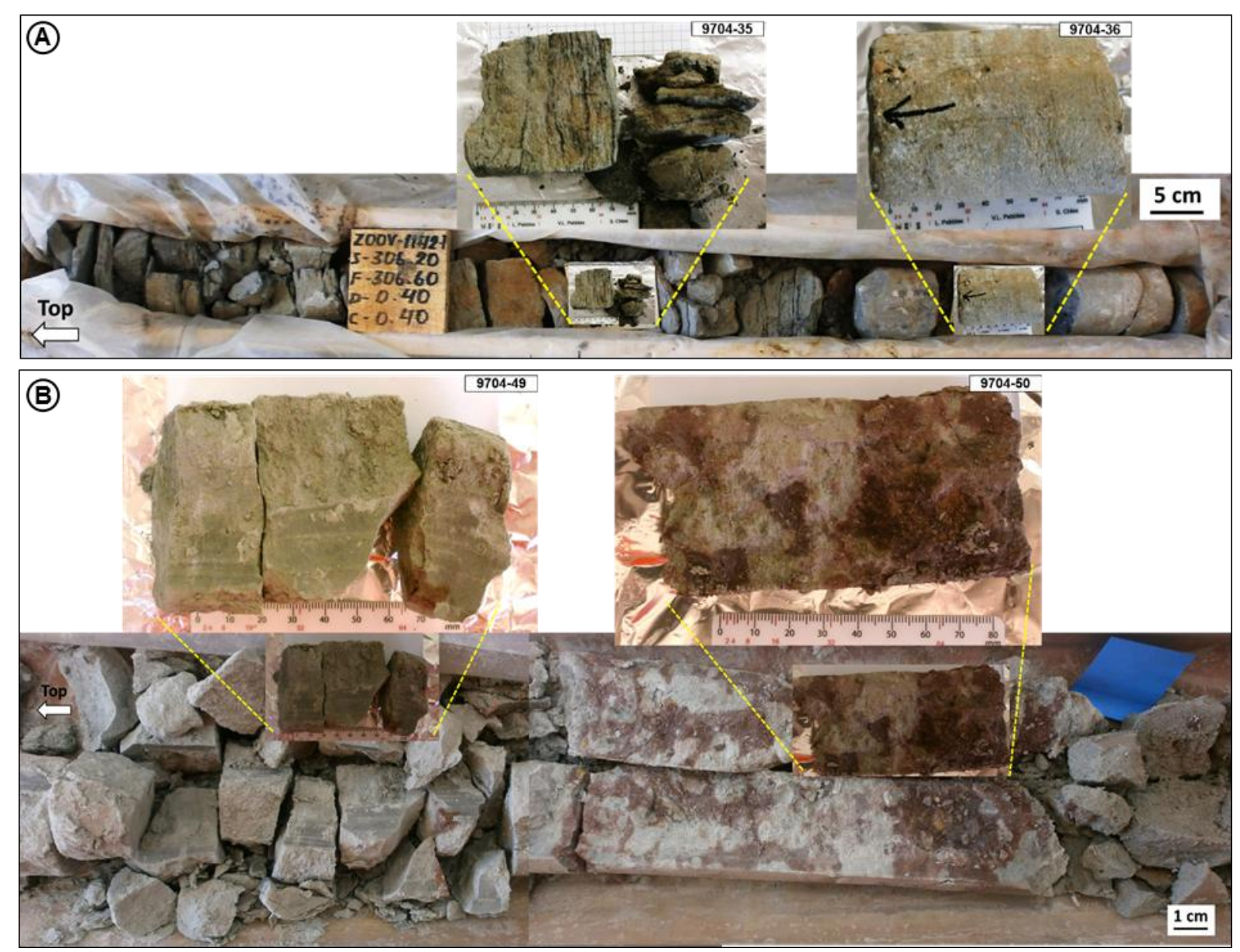

Figure 4 

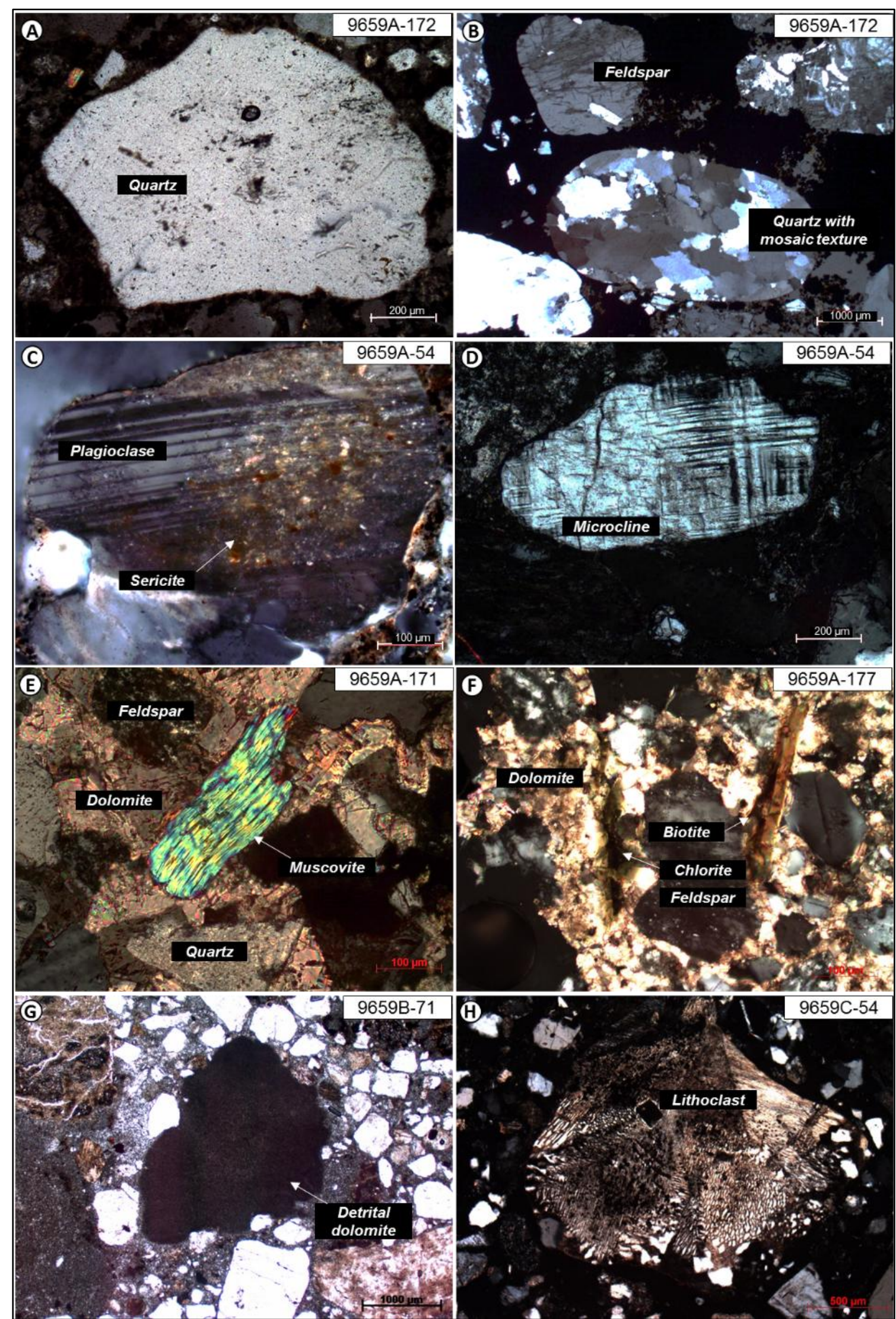

Figure 5 


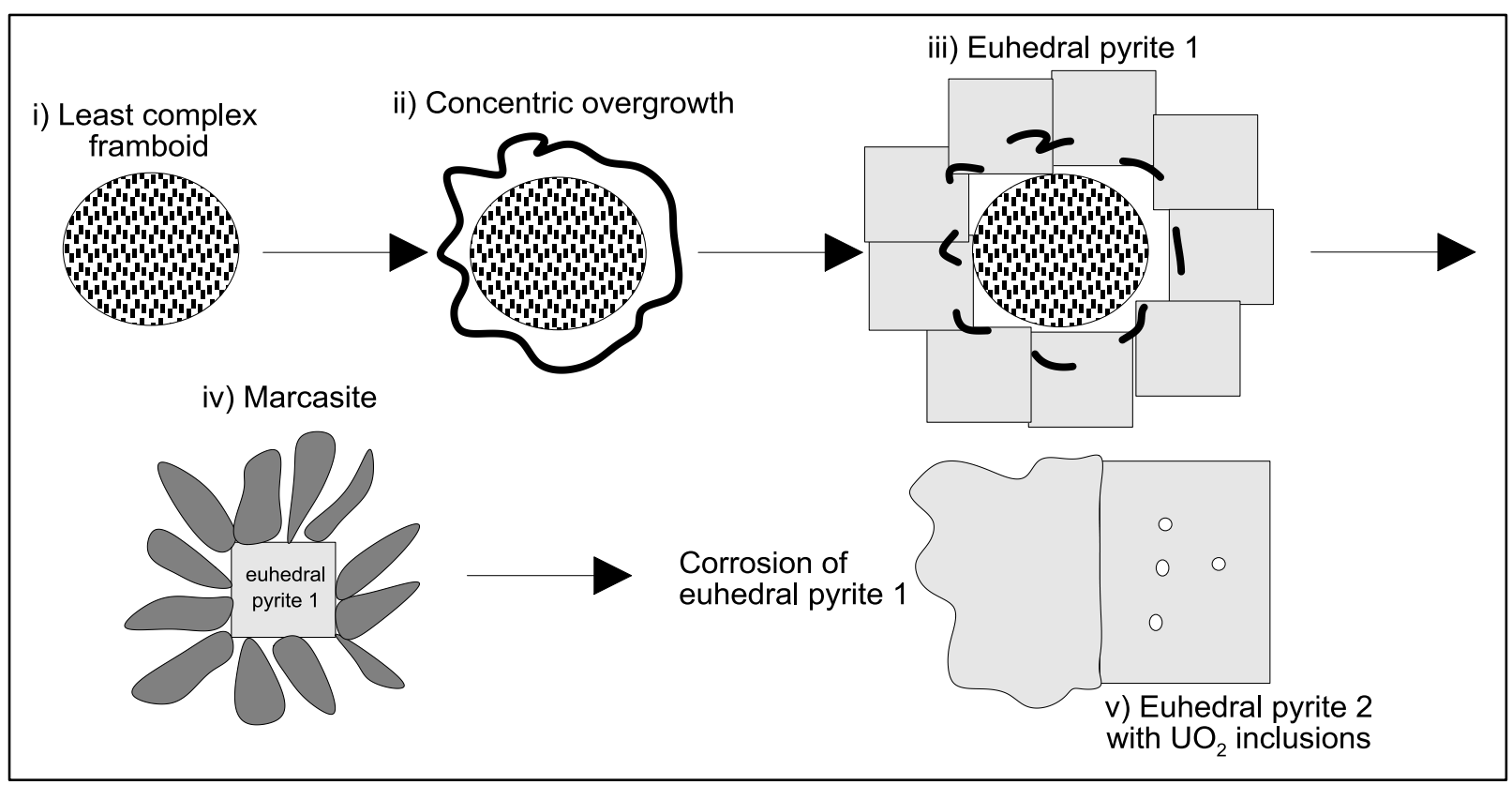

Figure 6 


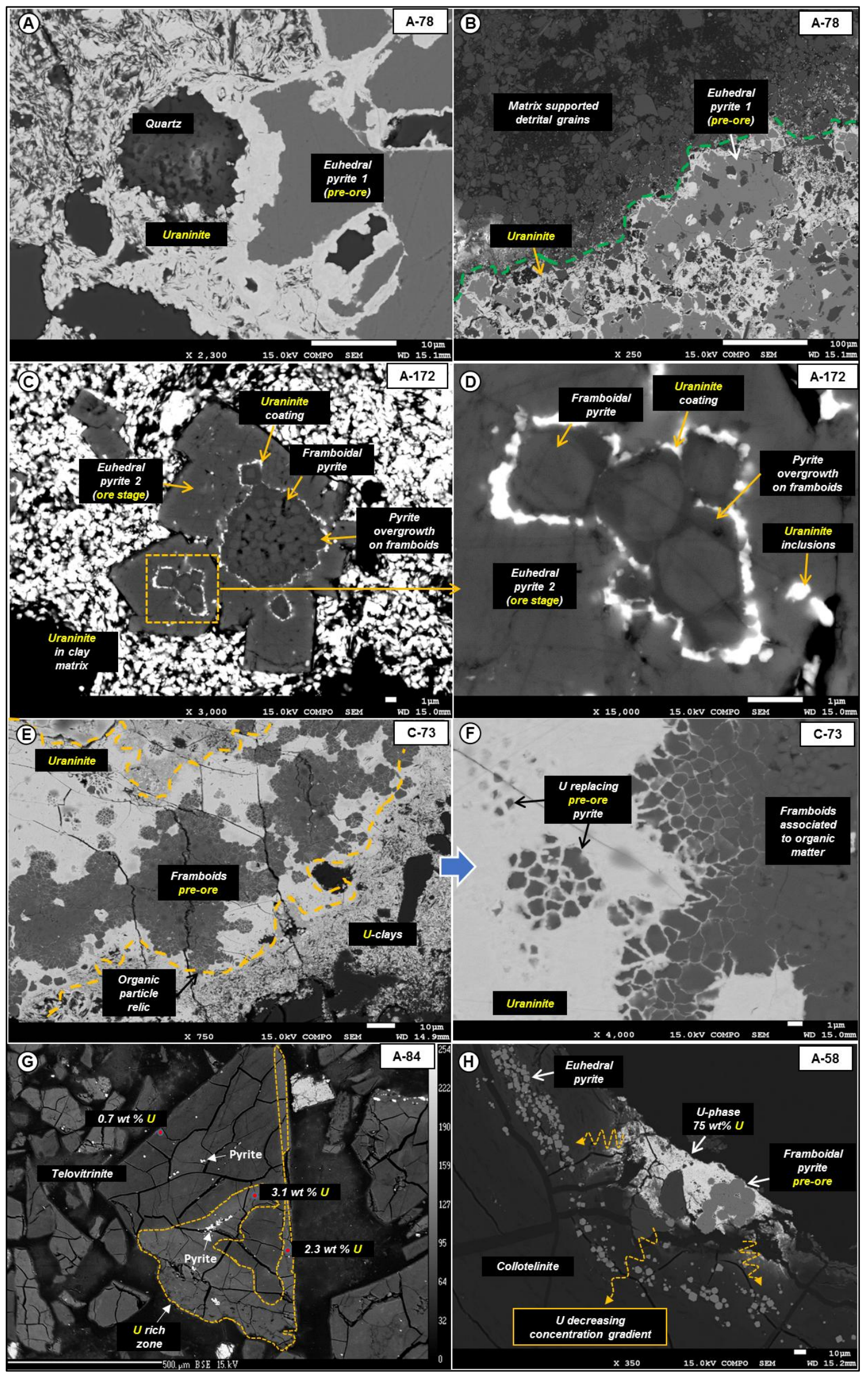

Figure 7 


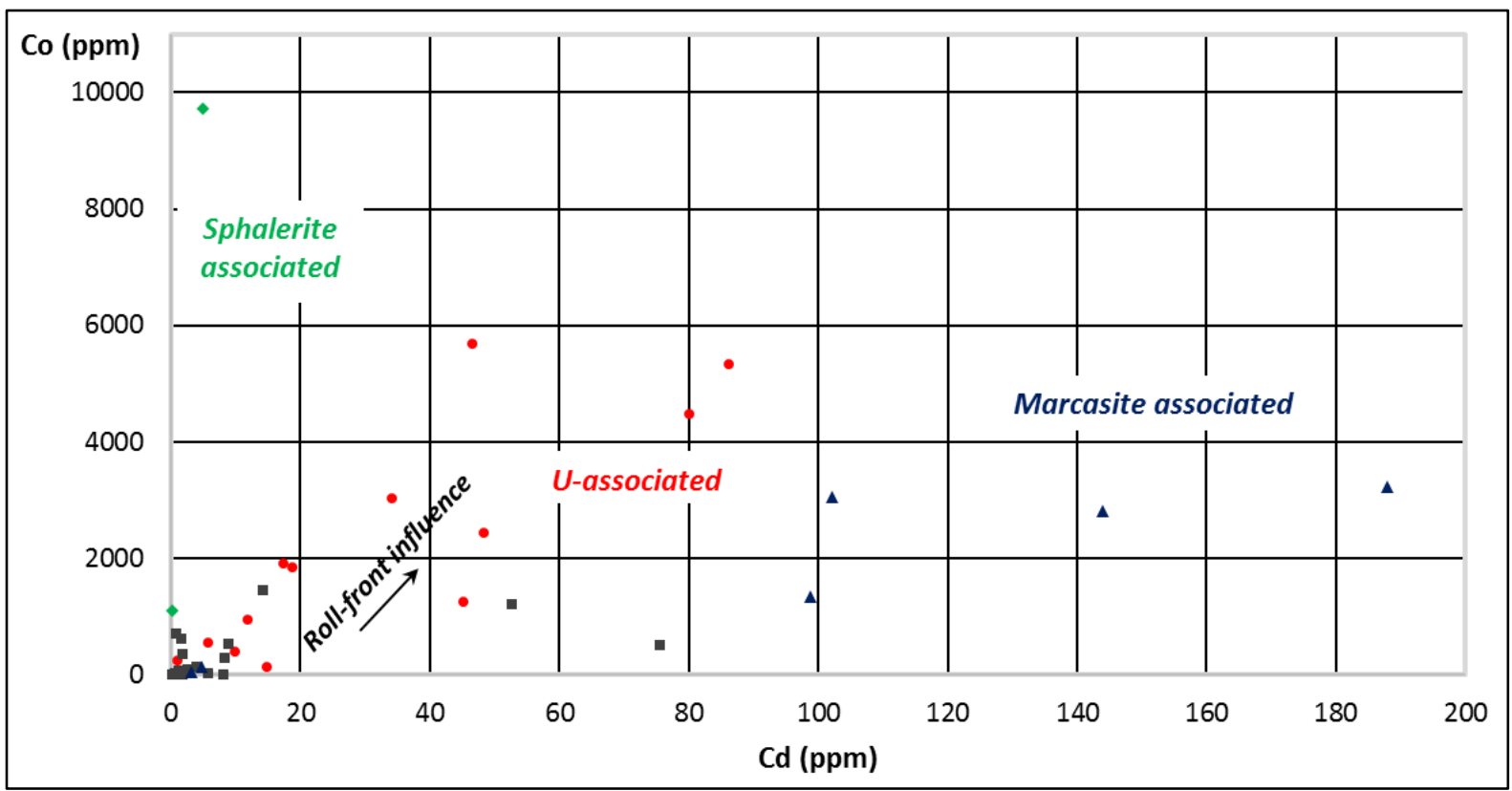

Figure 8

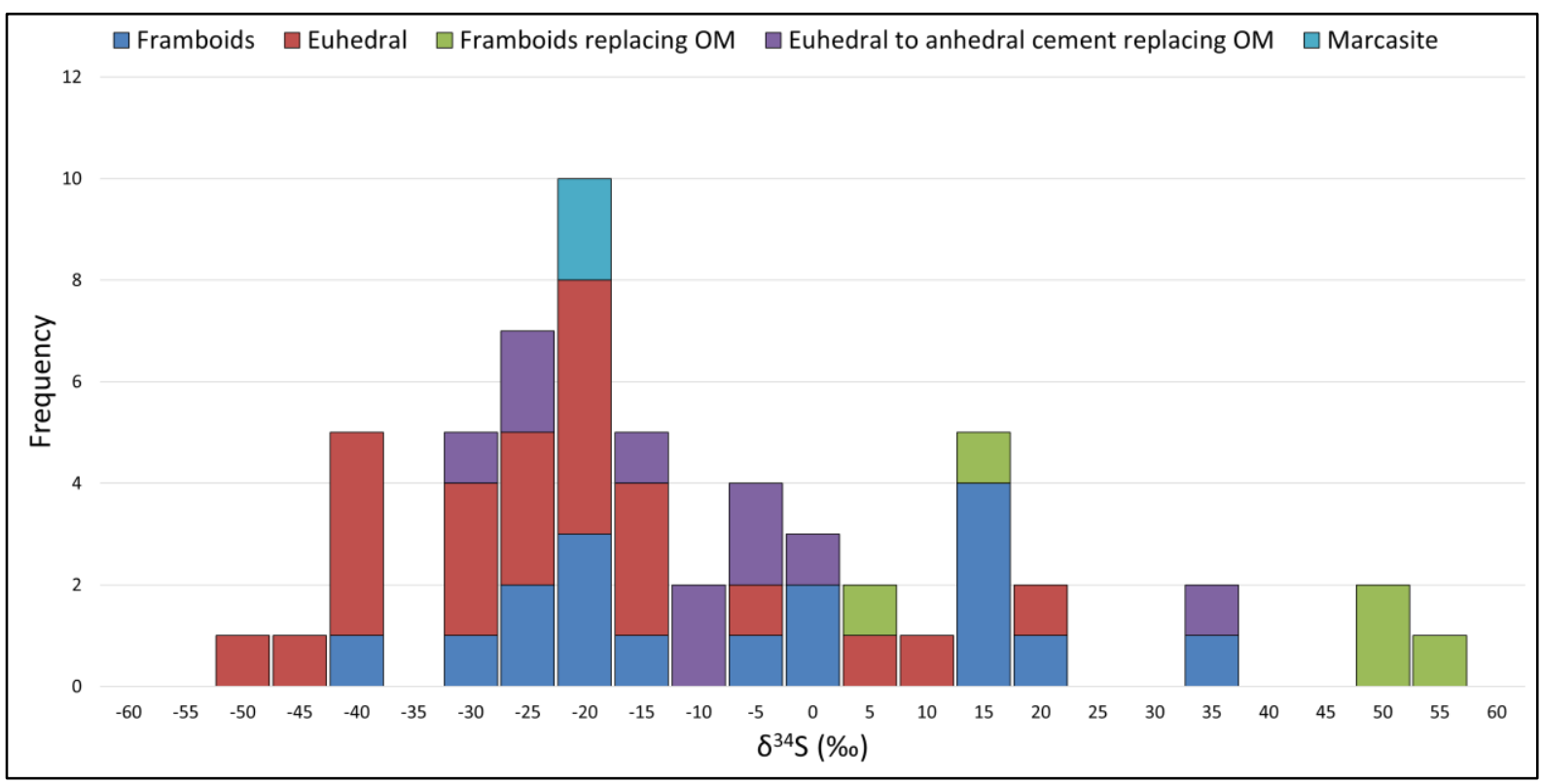

Figure 9 


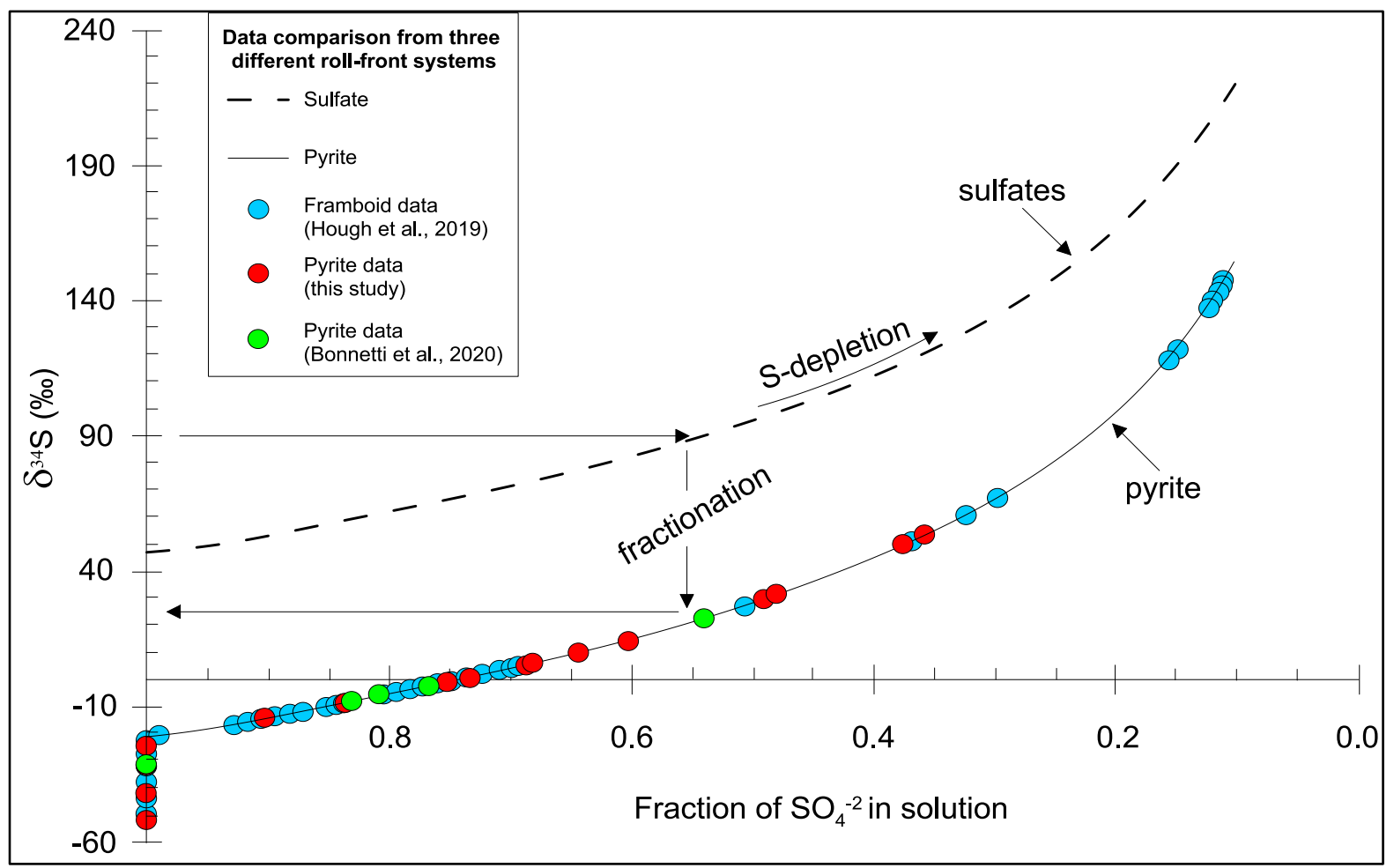

Figure 10

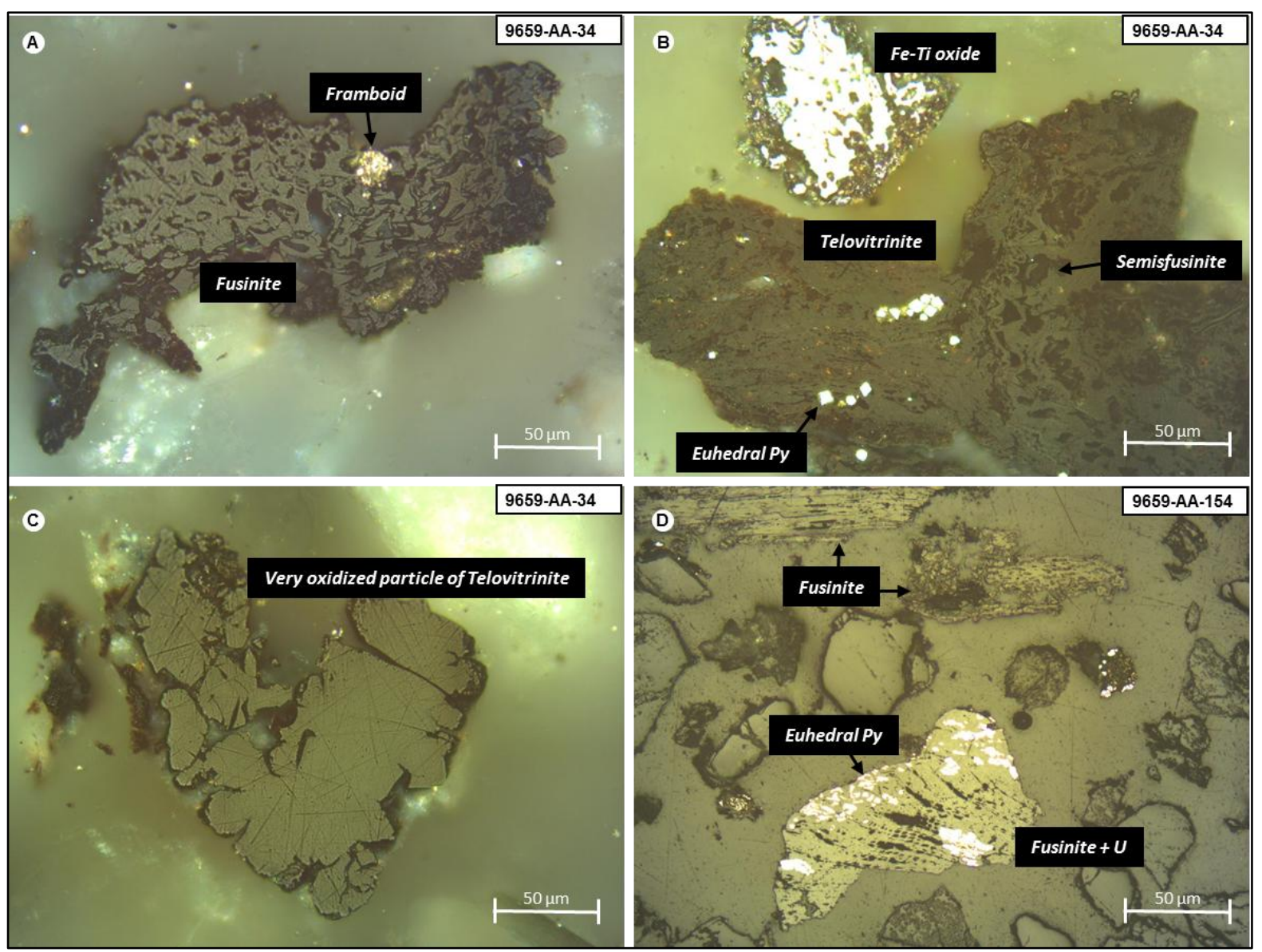

Figure 11 


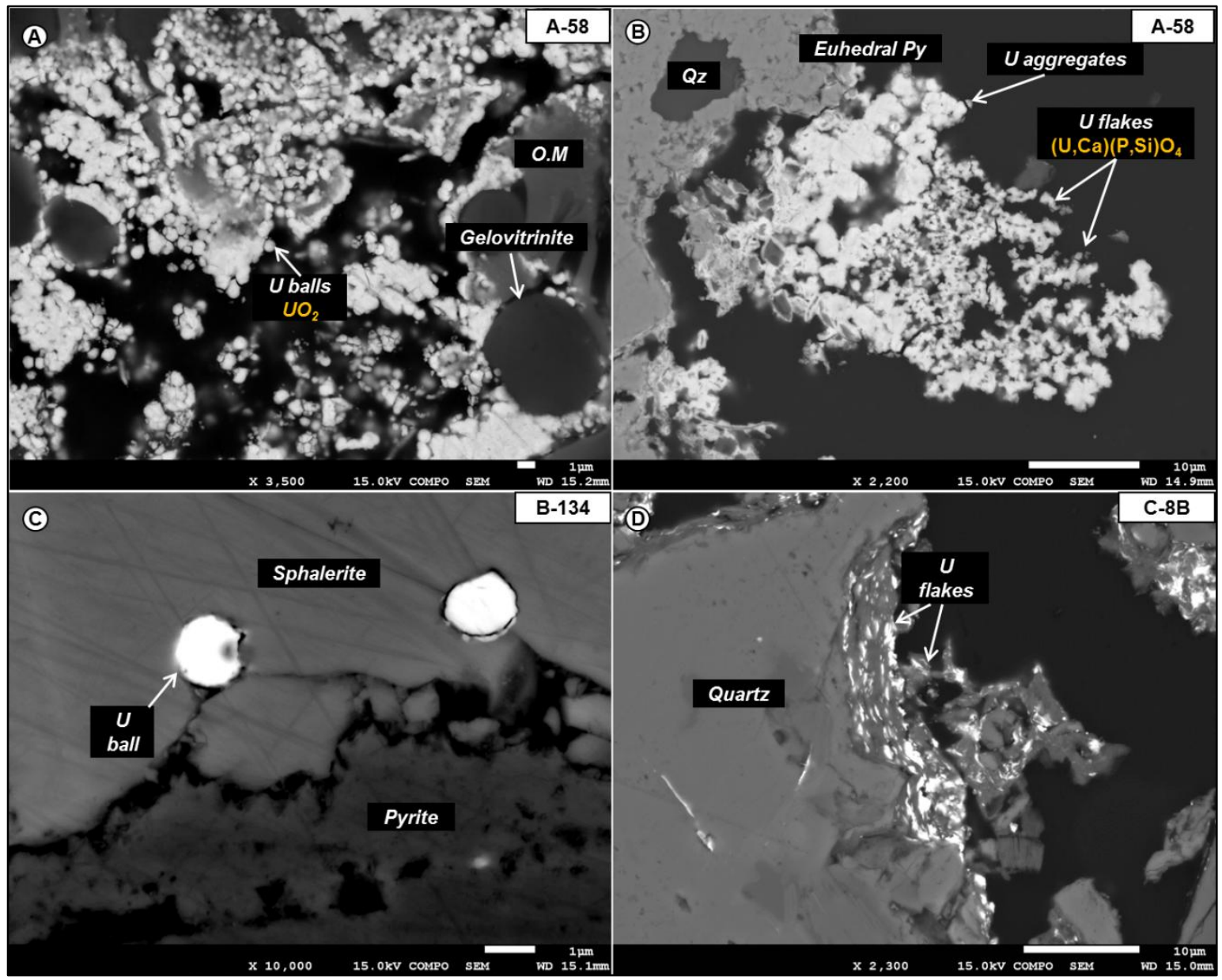

Figure 12 


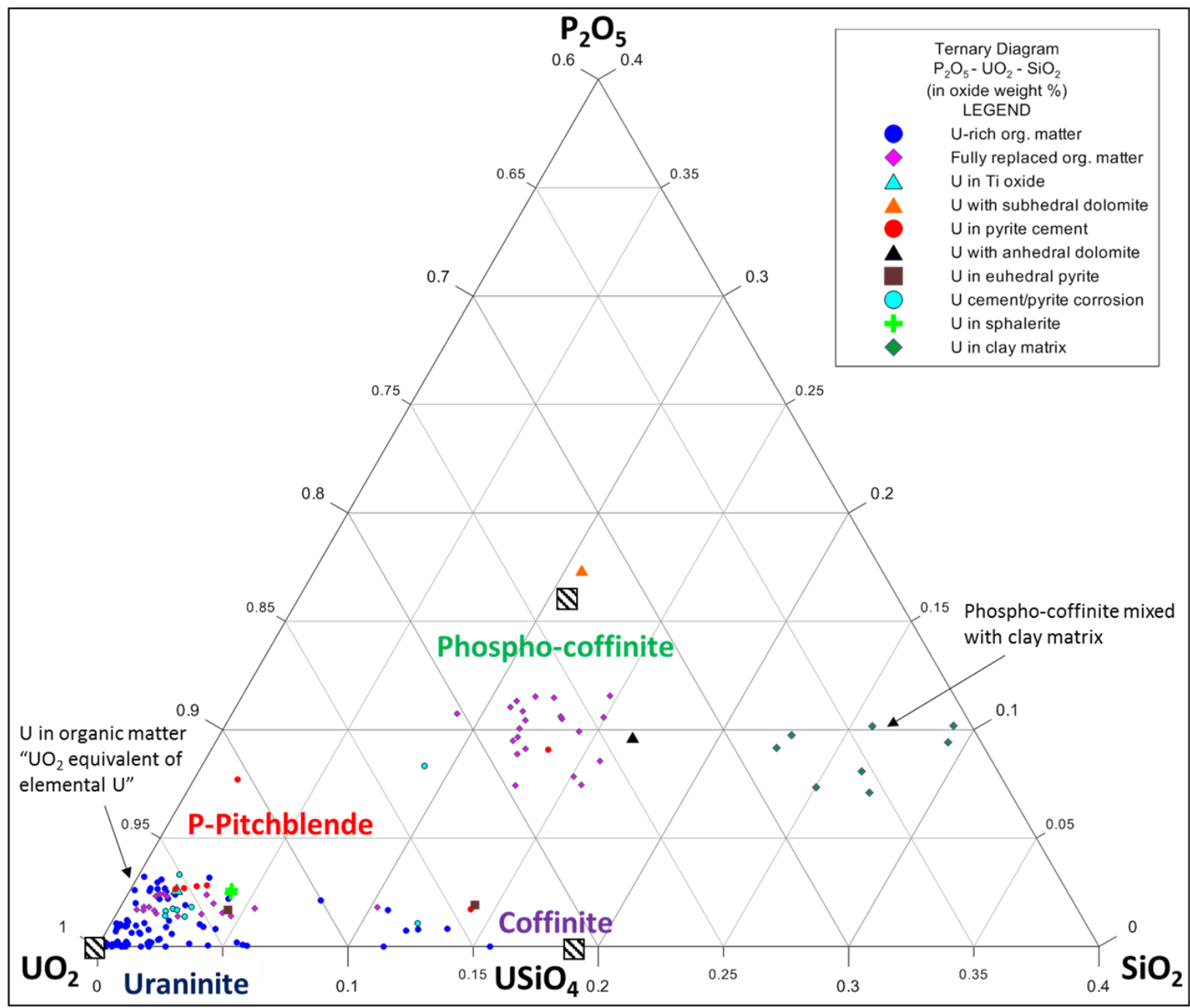

Figure 13 


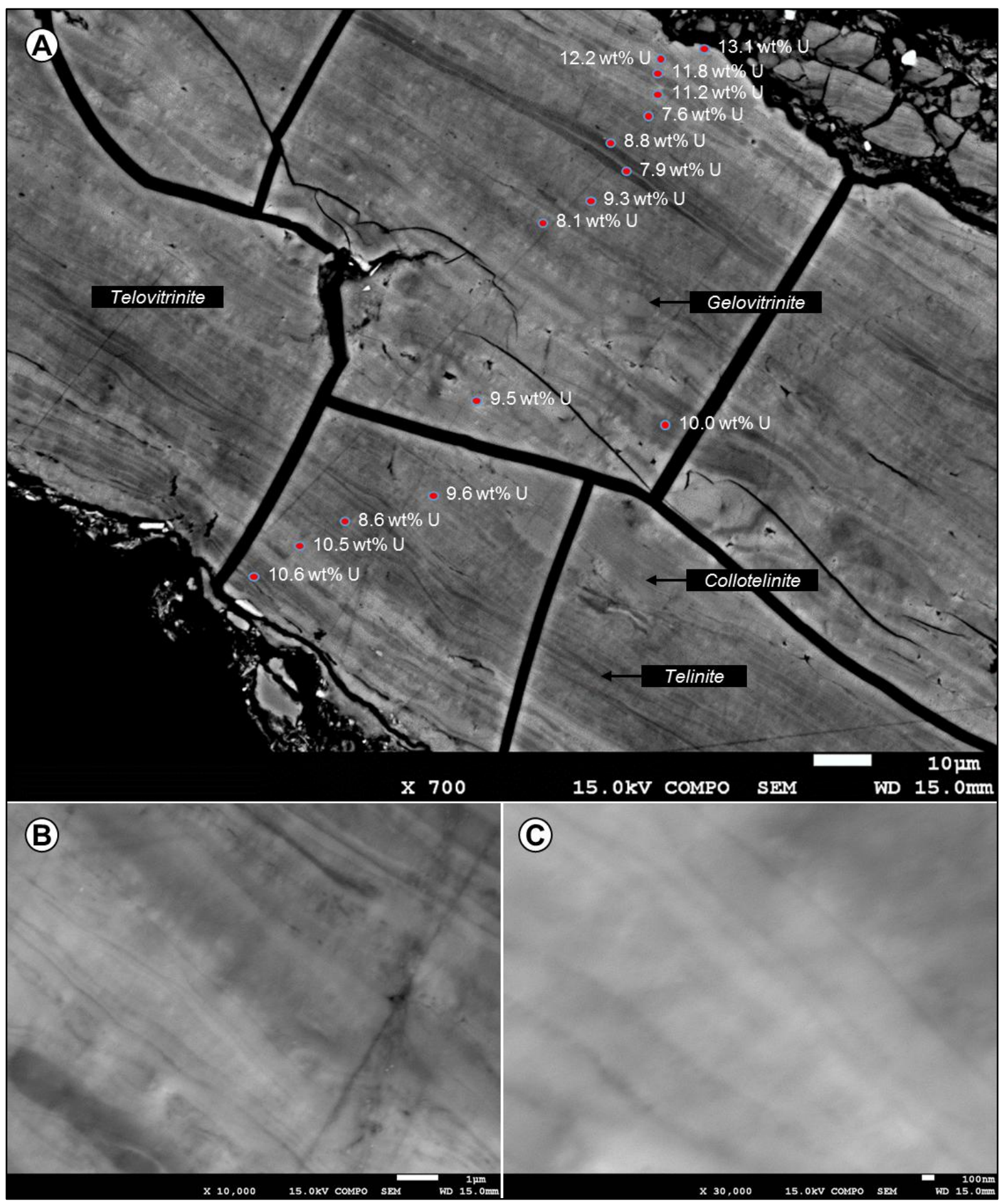

Figure 14 


\begin{tabular}{|l|l|l|l|l|}
\hline \multicolumn{2}{|l|}{ PARAGENETIC EVENT CHART } \\
Diagenetic events and minerals
\end{tabular}

Figure 15

ABIOTIC REDUCTION PROCESSES

a) Dissolution of $\mathrm{FeS}_{2}$

$\mathrm{FeS}_{2}+2 \mathrm{H}^{+} \longrightarrow \mathrm{Fe}^{2+}+2 \mathrm{HS}^{-}$

b) Reduction by reduced sulfur

$2 \mathrm{HS}^{-}+\mathrm{U}^{\mathrm{VI}} \longrightarrow \mathrm{U}^{\mathrm{IV}}+2 \mathrm{H}^{+}+2 \mathrm{~S}^{0}$

c) Reduction by reduced iron

$2 \mathrm{Fe}^{2+}{ }_{(\mathrm{s})}+\mathrm{U}^{\mathrm{Vl}}+4 \mathrm{H}_{2} \mathrm{O} \rightleftarrows 2 \mathrm{a}-\mathrm{FeOOH}+\mathrm{U}^{\mathrm{IV}}+6 \mathrm{H}^{+}$

Figure 16 


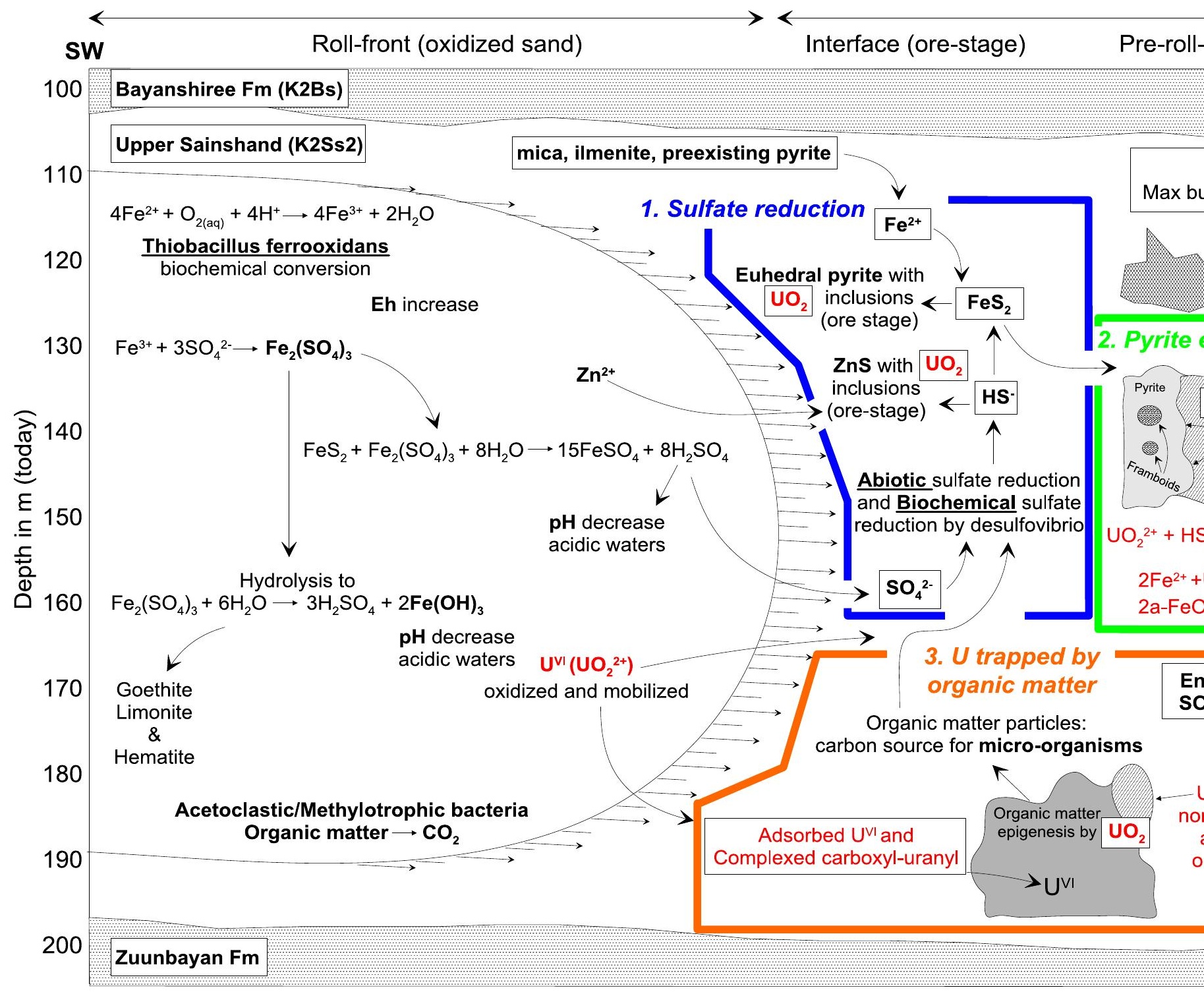

Figure 17 


\section{TABLES}

Table 1: Rock-Eval data for different lithologies, namely: sand with organic matter $(\mathrm{OM})$, black claystone and carbonate-cemented sandstone with organic matter. Radioactivity measurement in CPS (counts of radioactivity per second) using a Radiagem SPP2 detector. Background radioactivity $70 \mathrm{cps}$. Rock-Eval indices: S1 amount of free hydrocarbons ( $\mathrm{mg}$ of hydrocarbons per gram of sample); S2 oil potential ( $\mathrm{mg}$ hydrocarbon per gram of sample); TOC Total organic Content (in weight \%); Tmax: thermal maturity index in degree Celcius; HI: Hydrogen Index (mg of hydrocarbons per gram of organic carbon); OI: Oxygen index (mg of $\mathrm{CO}_{2}$ per gram of organic carbon)

Table 1

\begin{tabular}{|c|c|c|c|c|c|c|c|c|}
\hline Sample & Description & $\begin{array}{c}\text { S1 } \\
\mathrm{mgHC} / \text { g.rock }\end{array}$ & $\begin{array}{c}\text { S2 } \\
\mathrm{mgHC} / \text { g.rock }\end{array}$ & TOC(\%) & Tmax $\left({ }^{\circ} \mathbf{C}\right)$ & HI & OI & CPS \\
\hline $9704-08$ & Sand with OM & 0.01 & 0.22 & 1.56 & 420 & 14 & 163 & 914 \\
\hline $9704-9$ & Black claystone & 0 & 0.07 & 0.34 & 428 & 21 & 65 & 132 \\
\hline $9704-11$ & Black claystone & 0 & 0.11 & 0.67 & 430 & 16 & 57 & 70 \\
\hline $9704-17$ & Sand with OM & 0.01 & 0.17 & 1.08 & 418 & 16 & 152 & 90 \\
\hline $9704-40$ & Carb-cemented & 0.01 & 0.44 & 2.54 & 423 & 17 & 109 & 97 \\
\hline 9704-47 & sandstone with OM & 0.01 & 0.4 & 1.53 & 431 & 26 & 121 & 70 \\
\hline 9704-150 & Black claystone & 0.01 & 1.34 & 8.01 & 340 & 17 & 163 & 76 \\
\hline 9659A-72 & Sand with OM & 0.03 & 0.6 & 3.07 & 377 & 20 & 122 & 70 \\
\hline 9659A-116 & Sand with OM & 0.07 & 0.48 & 7.29 & 240 & 7 & 220 & 105 \\
\hline 9659A-34 & Sand with OM & 0.05 & 0.3 & 2.18 & 410 & 14 & 101 & 70 \\
\hline 9659A-62 & Sand with OM & 0.08 & 0.57 & 2.41 & 417 & 24 & 134 & 70 \\
\hline 9659A-84 & Sand with OM & 0.06 & 0.73 & 17.57 & 358 & 4 & 172 & 70 \\
\hline 9659A-151 & Sand with OM & 0.02 & 0.1 & 0.38 & 415 & 26 & 97 & 70 \\
\hline 9659A-154 & Sand with OM & 0.04 & 0.17 & 3.25 & 303 & 5 & 171 & 70 \\
\hline
\end{tabular}


Table 2: Sulfate and iron-reducing bacteria, as well as the methanogens, can enzymatically reduce uranium to form uranium oxides such as uraninite.

Table 2

\begin{tabular}{ll}
\hline Bacteria strains & Chemical reactions \\
\hline $\begin{array}{l}\text { 1. Iron reducing bacteria } \\
\text { Geobacter metallireducens } \\
\text { Lovley et al. (1991) }\end{array}$ & $\mathrm{CH}_{3} \mathrm{COO}^{-}+8 \mathrm{Fe}^{+3}+4 \mathrm{H}_{2} \mathrm{O} \rightarrow 2 \mathrm{HCO}_{3}{ }^{-}+8 \mathrm{Fe}^{+2}+4 \mathrm{H}^{+}$ \\
\cline { 2 - 2 } $\begin{array}{l}\text { 2. Sulfate reducing bacteria } \\
\text { Desulfovibrio sulfuricans \& sulfosprosinus } \\
\text { Lovley et al. (1993); Cardenas et al. (2010) }\end{array}$ & $\mathrm{CH}_{3} \mathrm{COOH}+\mathrm{SO}_{4}{ }^{-2}+4 \mathrm{H}^{+} \rightarrow \mathrm{HS}^{-}+2 \mathrm{HCO}_{3}^{-}+3 \mathrm{H}^{+}$ \\
\cline { 2 - 2 } $\begin{array}{l}\text { 3. Methanogens } \\
\begin{array}{l}\text { Methanosarcina } \\
\text { Holmes et al. (2018) }\end{array}\end{array}$ \\
\hline $\begin{array}{l}\text { The same bacteria strains may reduce } \\
\text { uranium based on the following reaction }\end{array}$ & $\mathrm{CH}_{3} \mathrm{COOH} \rightarrow 2 \mathrm{CH}_{4}+\mathrm{CO}_{2}$ \\
\hline &
\end{tabular}




\section{ANNEX (SUPPLEMENTARY MATERIAL)}

Figure A1: Clustered bar chart indicating the lithofacies distribution in Zoovch Ovoo, expressed in percent, as identified by point-counting method on the basis of 97 samples.

Figure A2: The $\log \left(\mathrm{Fe}_{2} \mathrm{O}_{3} / \mathrm{K}_{2} \mathrm{O}\right)$ versus $\log \left(\mathrm{SiO}_{2} / \mathrm{Al}_{2} \mathrm{O}_{3}\right)$ after Herron, 1988. Data from bulk rock analysis (ICP-MS).

Figure A3: A Diffractogram of oriented section under air-dried (AD) conditions and after ethylene-glycol (EG) treatment, for the sample 9704-45 (black silty-clay from the mineralized zone).

Figure A4: Cross-plot between Hydrogen Index and Oxygen index. Symbols coloured according to radioactivity (cps- counts per second) content of the whole rock. Data indicate that kerogen is of Type III (higher plants derived), consistent with organic petrography observations. The zoomed part of the diagram on the right suggests no relationship between kerogen oxygen content and alteration by radioactivity.

Figure A5: Chondrite-normalized rare earth element patterns for $\mathrm{UO}_{2}$ in three different petrographic situations: A) $\cup_{2}$ replacing organic matter; B) associated with pyrite and $C$ ) within the clay matrix). In $D$, a comparison between the average REE concentrations of uranium oxides compared to the bulk rock.

Figure A6: SEM-BSE $(A, D, G)$ and their respective cathodoluminescence images under black-white $(B, E, H)$ and coloured mode $(C, F, I)$. In $A, B, C$, quartz grains, and other silicate detrital minerals, the absence of pleochroic halos indicates the lack of radiolytic alteration. In D, E, F, uranium cement in part around a quartz grain, which shows radiolytic alteration features, i.e. zonations of specific distance from the grain edge towards the inner part. When radiation damage rims are observed in the absence of uranium minerals, they indicate former long-term contact. Uranium minerals were precipitated and then dissolved, a process typical of uranium displacement and re-concentration linked to roll-front movement. $\mathrm{G}, \mathrm{H}$, I: quartz cement crystals have grown inside a vug of pyrite that was partially replaced by 
uranium cement. The zonations and the jagged and ingrown shape of the crystal point out its authigenic character.

Figure A7: Cross-plot between total organic carbon (TOC) and total sulfur content (bulk rock analysis). The diagram shows a significant relationship suggesting that organic matter is a prerequisite for pyrite growth.

Figure A8: Examples of framboids being embedded by euhedral pyrite. A, B: Typical example of a pyrite cluster with framboids within euhedral crystals, located in the intergranular porosity of a matrix-supported sandstone. The framboids $(20 \mu \mathrm{m})$ are densely packed and highly amalgamated with the euhedral grains, but they can be still discriminated against since they are composed of submicron pyrite crystals. The individual cubic crystals that form the aggregate are at the size of $10 \mu \mathrm{m}$ (BSE). C: Again, framboids encompassed by euhedral pyrite, this time growing on organic matter, particularly fusinite. Euhedral crystals not associated with framboids are also recognized (BSE). D: A cluster of framboidal pyrite encompassed by a generation of euhedral pyrite that contains uranium. The cluster is cemented by type III subhedral dolomite. E: Well-developed pyritospheres $(15 \mu \mathrm{m})$ surrounded by uraninite, followed by euhedral pyrite $(10-15 \mu \mathrm{m})$ with uraninite inclusions. The whole assemblage is within the clay matrix, where uraninite is also contained. There appears to be one euhedral pyrite generation (BSE). F: Group of well-developed framboids (up to 10 $\mu \mathrm{m}$ ) encompassed first by concentric overgrowth, then by euhedral pyrite at the size range of $5-10 \mu \mathrm{m}$, followed by uraninite precipitation and another a few $\mu \mathrm{m}$ thick euhedral pyrite generation (BSE). 


\section{$\%$ Distribution of lithofacies in Zoovch Ovoo}

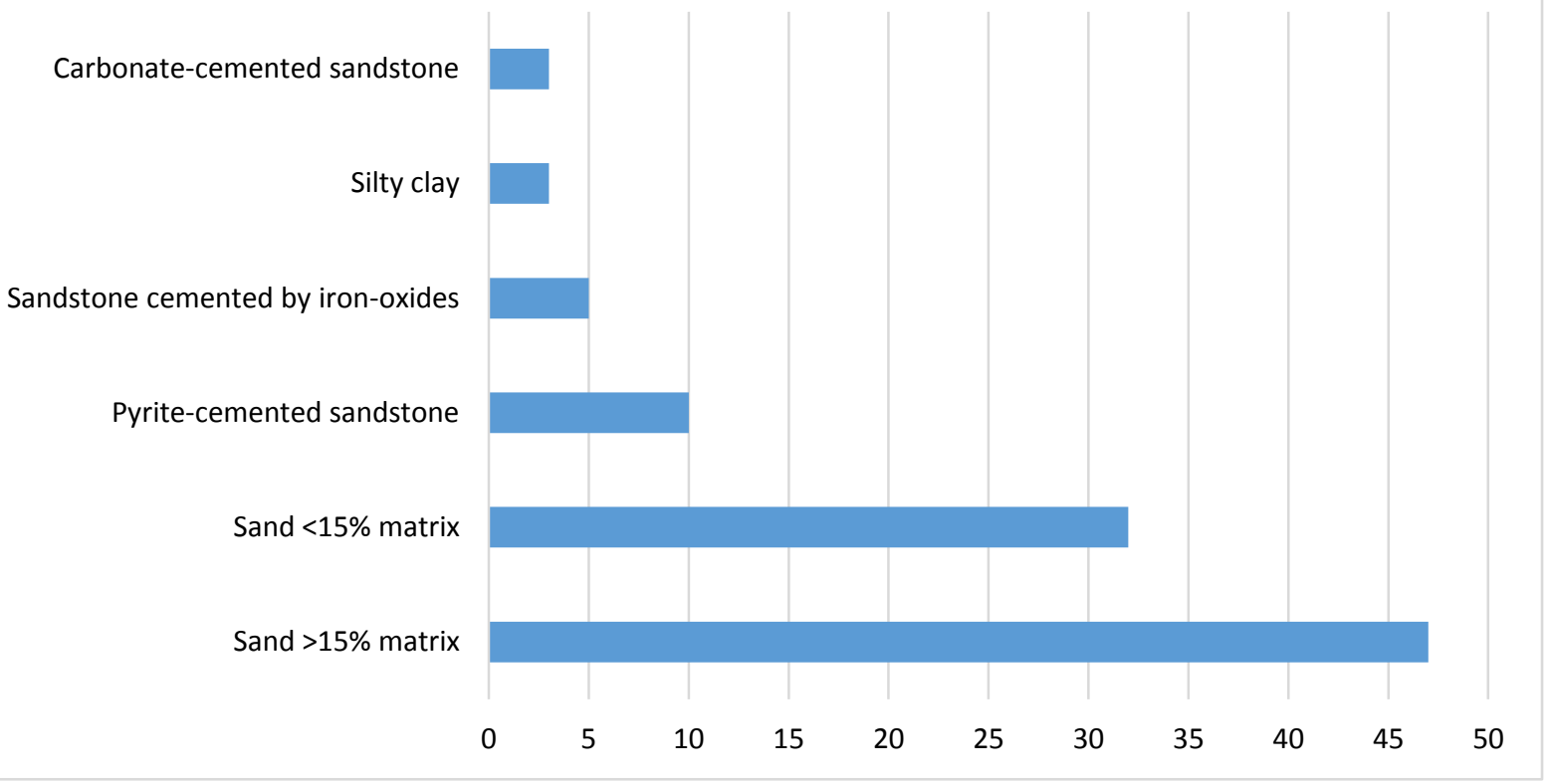

Figure A1

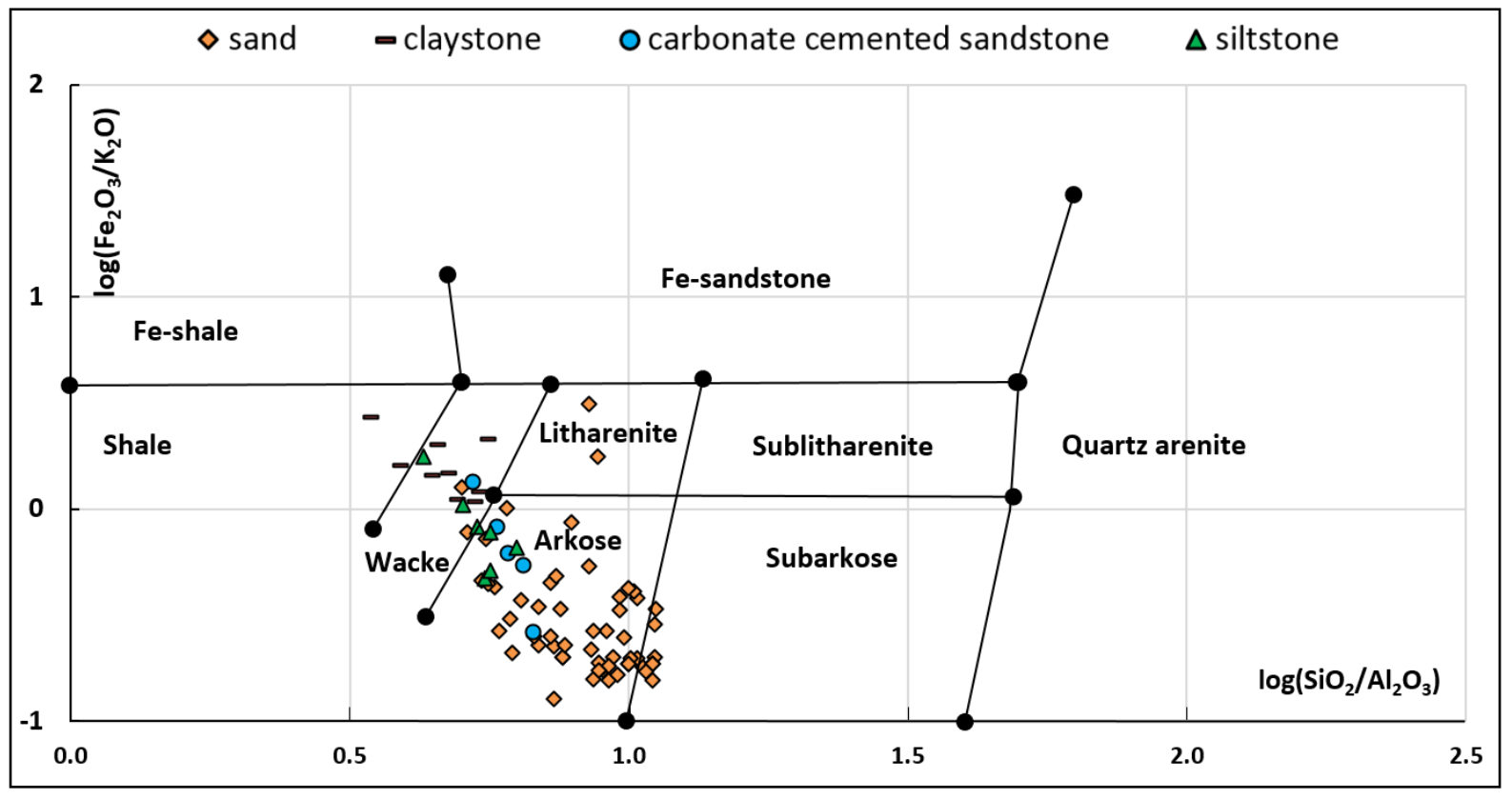

Figure A2 


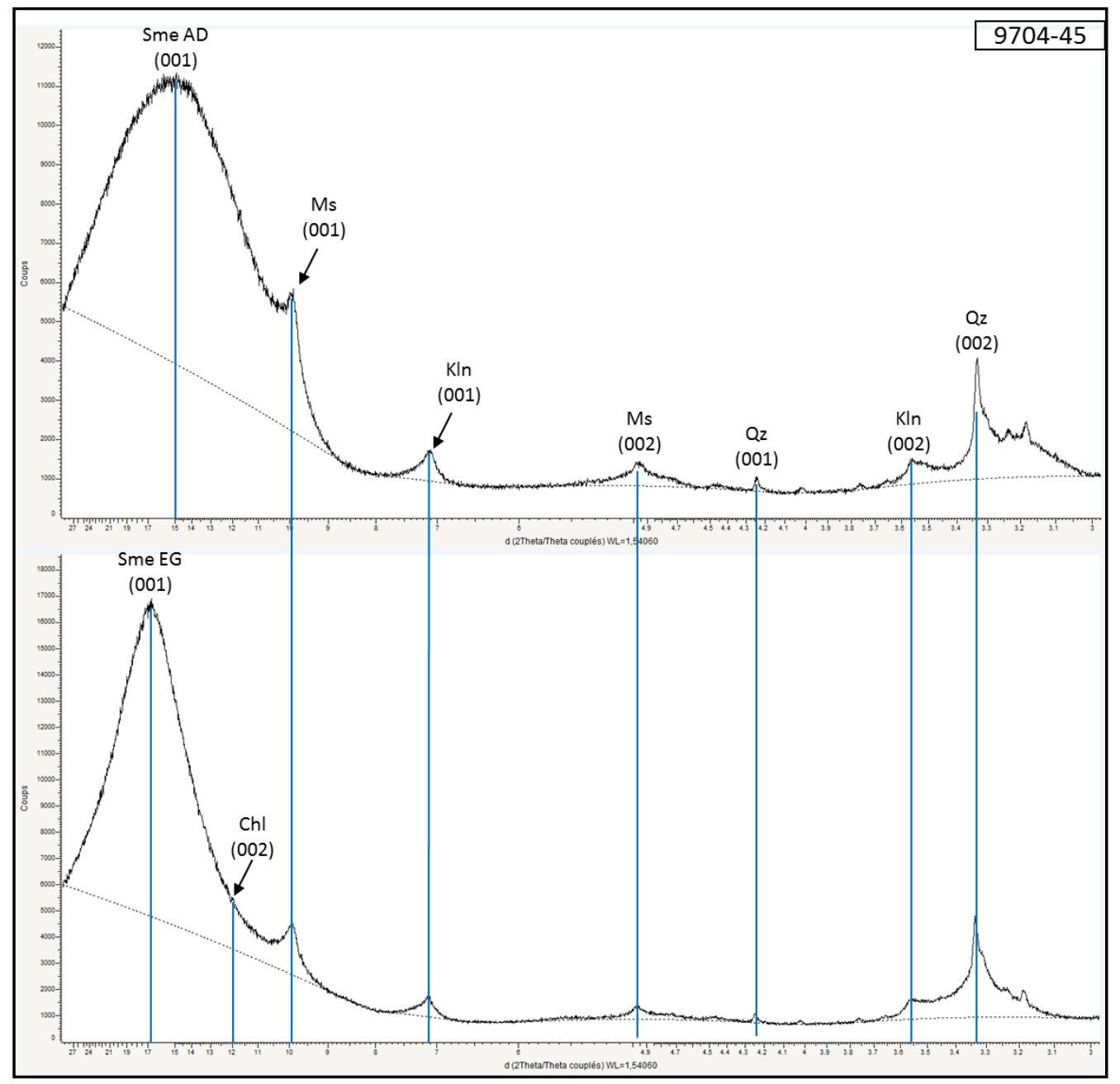

Figure $A 3$

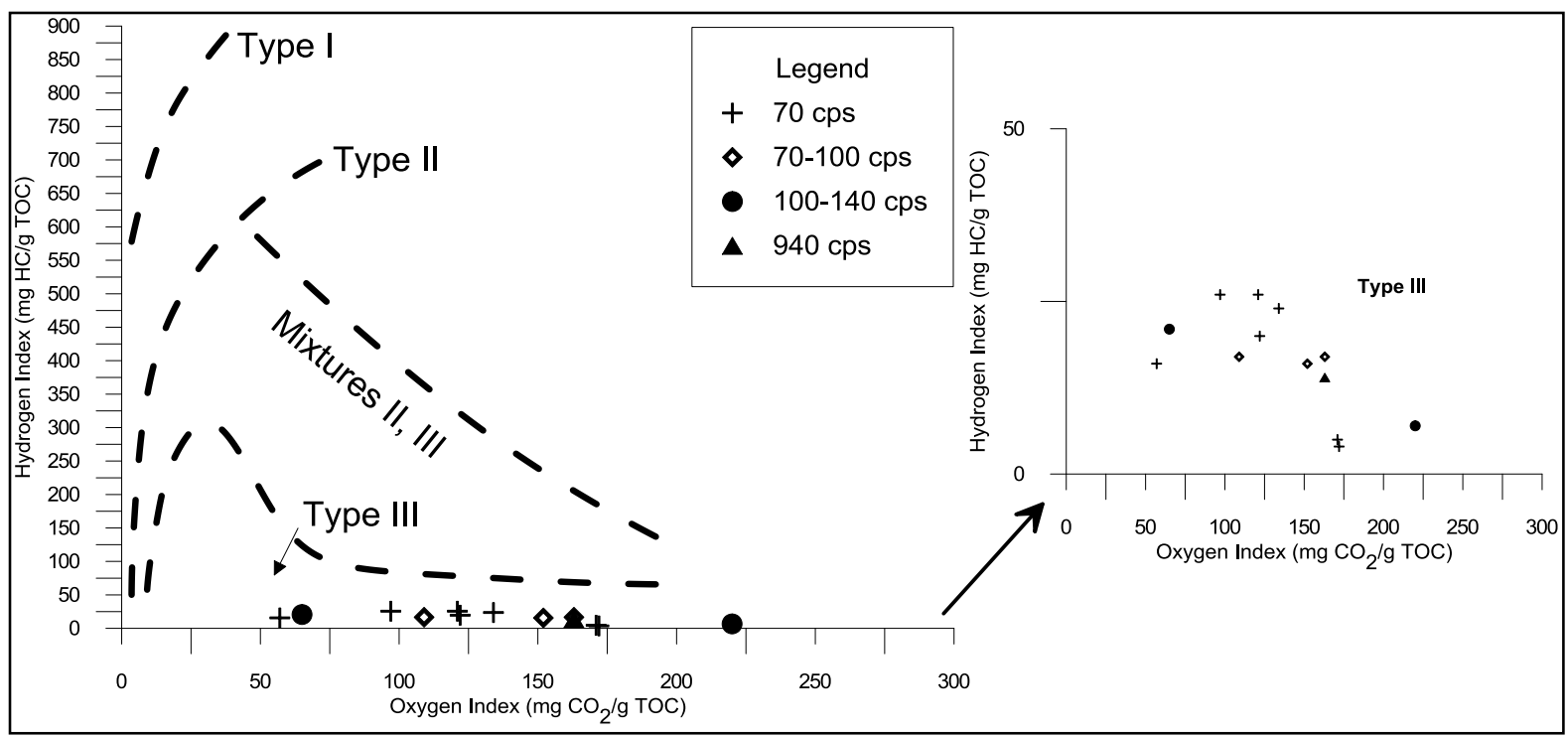

Figure A4 


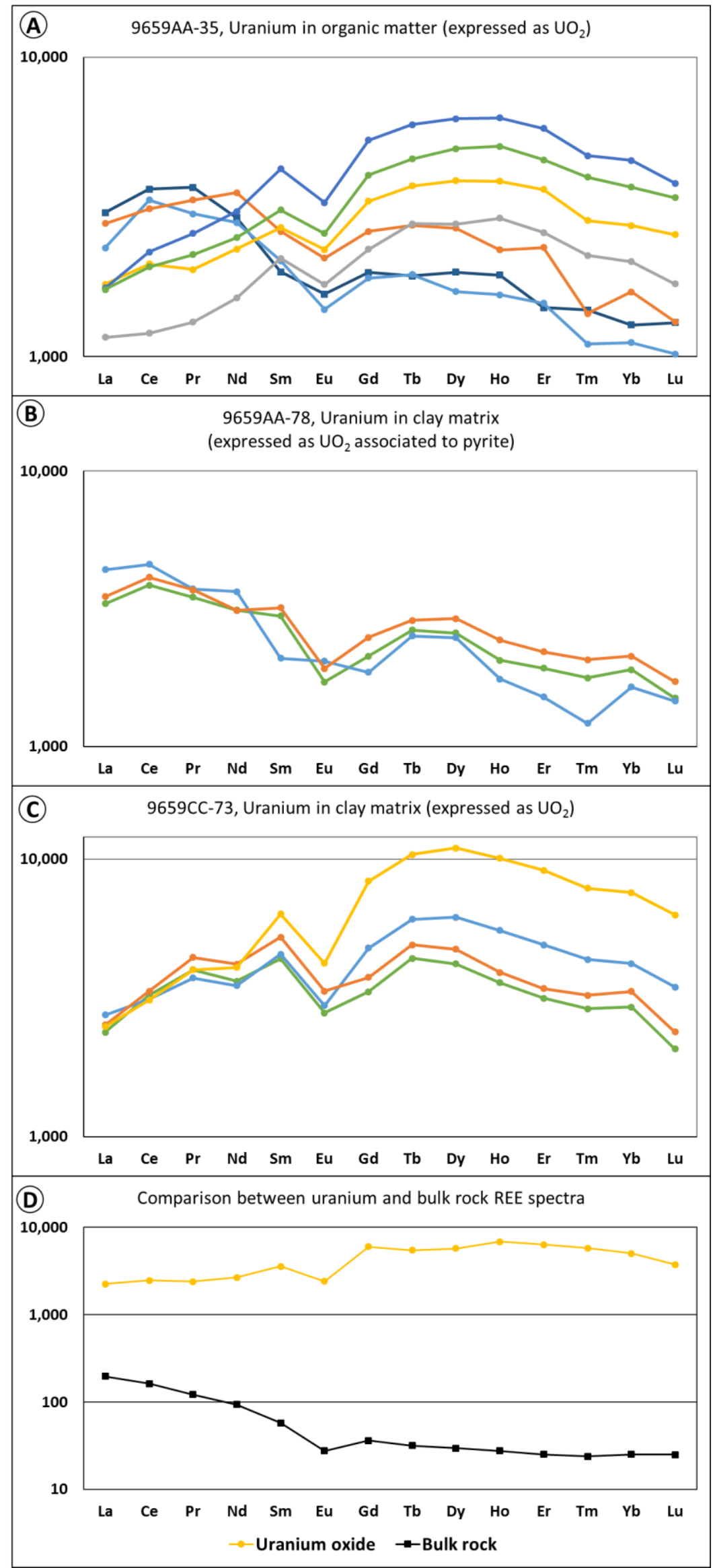

Figure A5 


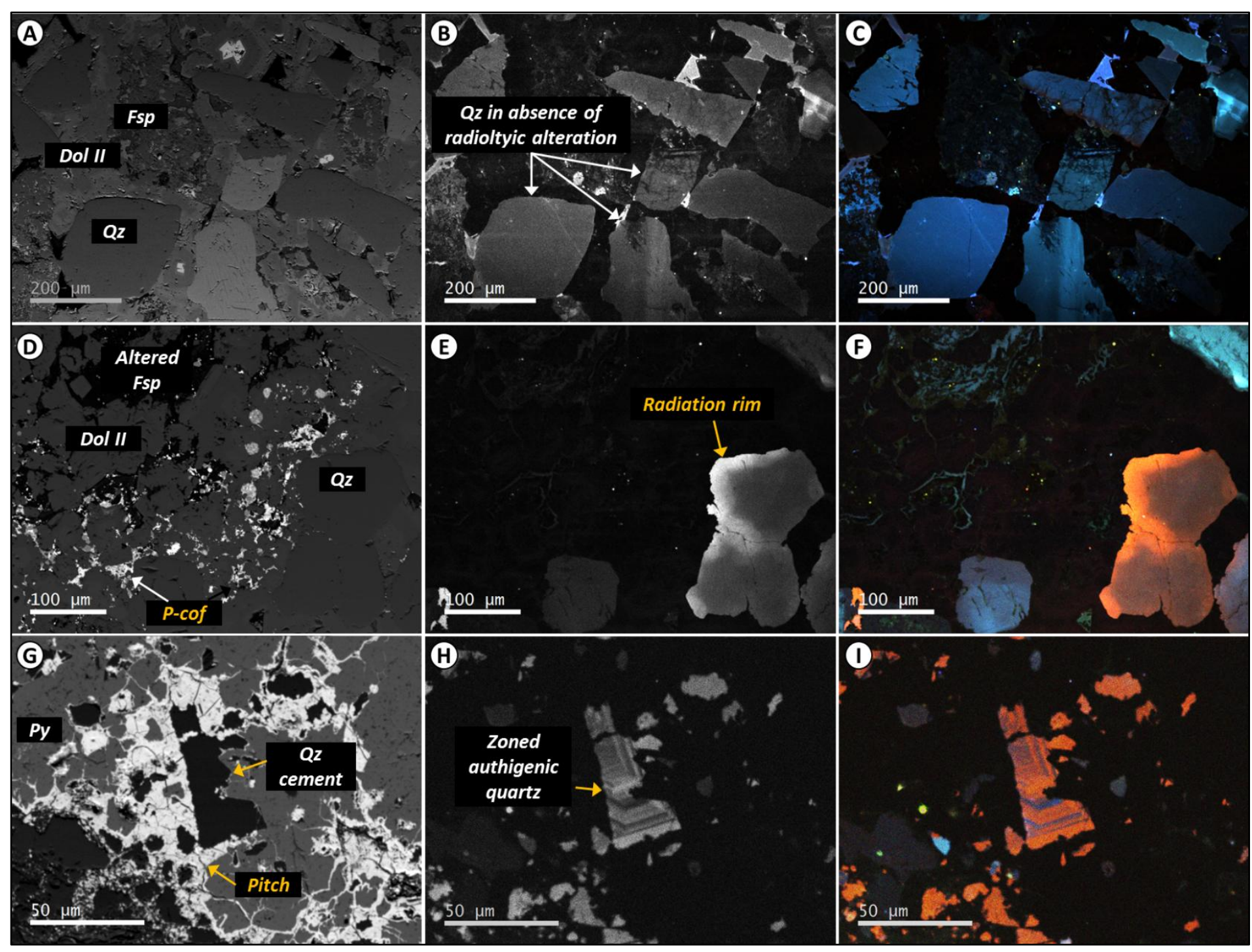

Figure A6 
$\mathrm{C}_{\text {org }}$ vs S plot (whole rock)
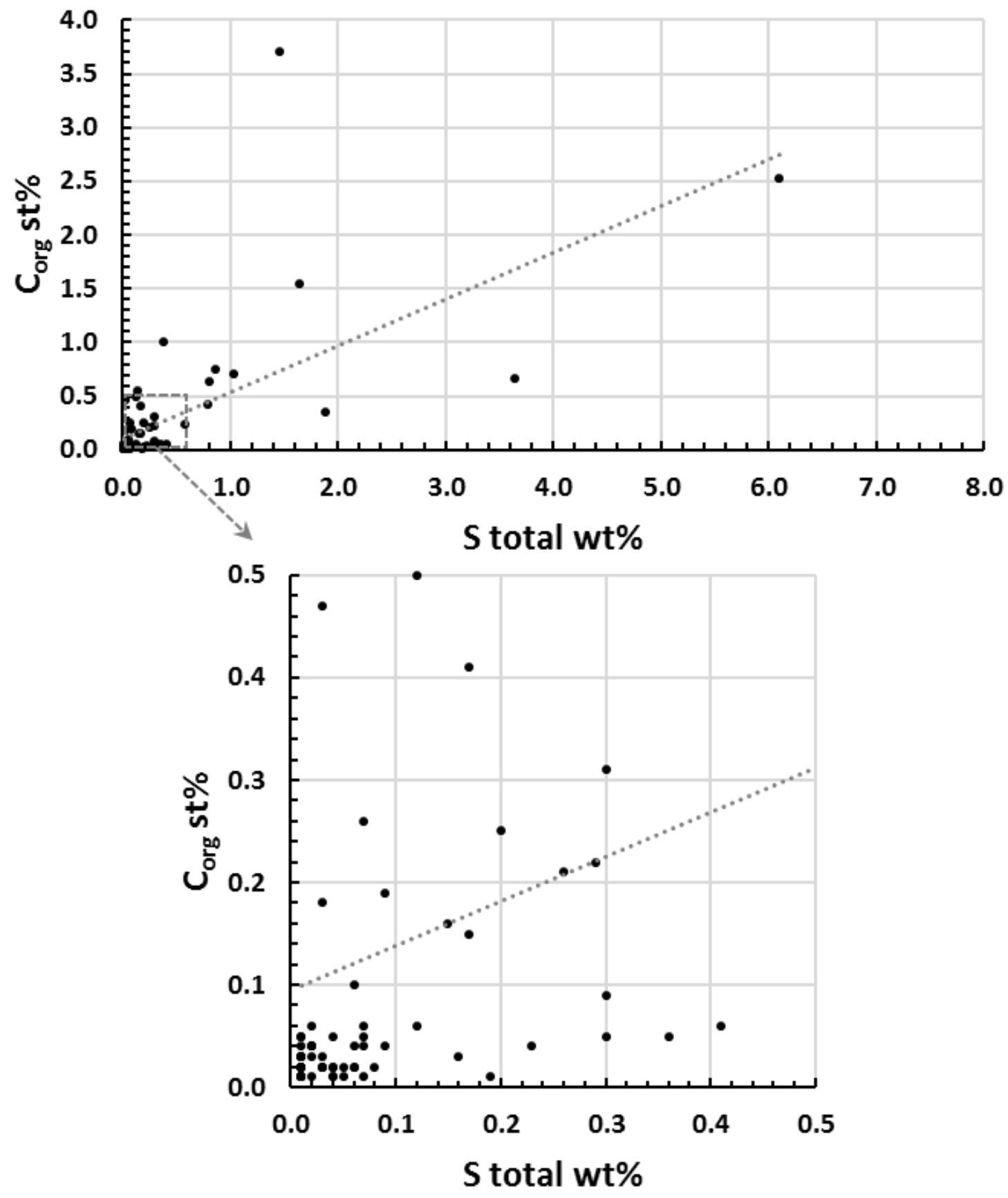


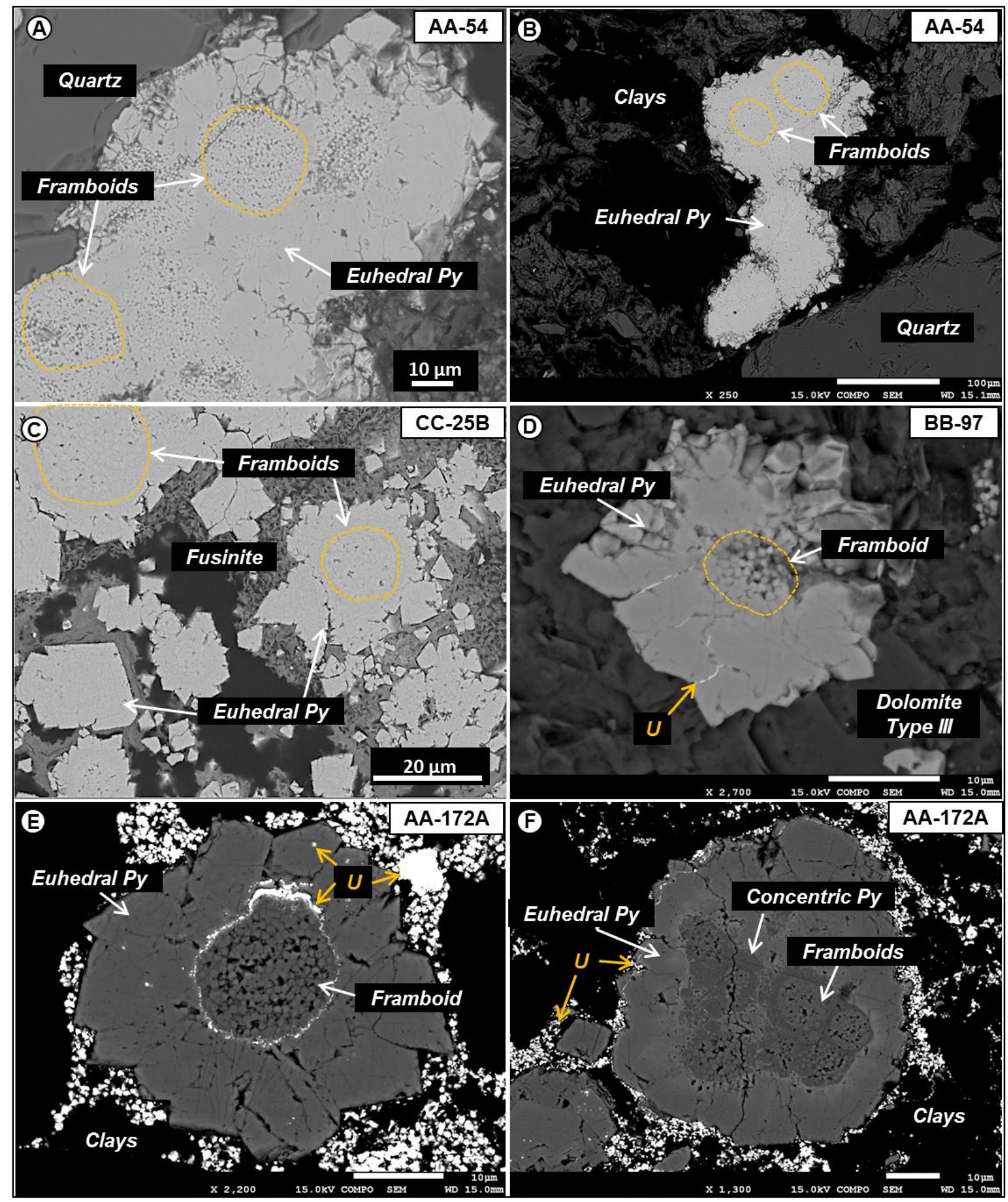

5 Figure A8

6 